\title{
Hartrevalidatie in Nederland geregistreerd en geevalueerd : een inventariserend onderzoek naar hartrevalidatie in Nederland
}

Citation for published version (APA):

Soons, P. H. G. M. (1995). Hartrevalidatie in Nederland geregistreerd en geevalueerd : een inventariserend onderzoek naar hartrevalidatie in Nederland. [Doctoral Thesis, Maastricht University]. Datawyse / Universitaire Pers Maastricht. https://doi.org/10.26481/dis.19950629ps

Document status and date:

Published: 01/01/1995

DOI:

10.26481/dis.19950629ps

Document Version:

Publisher's PDF, also known as Version of record

Please check the document version of this publication:

- A submitted manuscript is the version of the article upon submission and before peer-review. There can be important differences between the submitted version and the official published version of record.

People interested in the research are advised to contact the author for the final version of the publication, or visit the DOI to the publisher's website.

- The final author version and the galley proof are versions of the publication after peer review.

- The final published version features the final layout of the paper including the volume, issue and page numbers.

Link to publication

\footnotetext{
General rights rights.

- You may freely distribute the URL identifying the publication in the public portal. please follow below link for the End User Agreement:

www.umlib.nl/taverne-license

Take down policy

If you believe that this document breaches copyright please contact us at:

repository@maastrichtuniversity.nl

providing details and we will investigate your claim.
}

Copyright and moral rights for the publications made accessible in the public portal are retained by the authors and/or other copyright owners and it is a condition of accessing publications that users recognise and abide by the legal requirements associated with these

- Users may download and print one copy of any publication from the public portal for the purpose of private study or research.

- You may not further distribute the material or use it for any profit-making activity or commercial gain

If the publication is distributed under the terms of Article 25fa of the Dutch Copyright Act, indicated by the "Taverne" license above, 
HARTREVALIDATIE IN NEDERLAND

GEREGISTREERD EN GEËVALUEERD 


\section{CIP.DATA KONINKLIJKE BIBLIOTHEEK DEN HAAG}

Soons : Paulus Hubertus Gerardus Marie

Hartrewalidatie in Nederland geregistreerd en geëvalueerd : een inventariserend onderzoek naar hartrevalidatie in Nederiand / Paullus Hubertus Gerardus Marie Soons. -

Maastricht : Universitaire Pers Maastricht. - Met

lit. opg. - Met samenvatting in hel Engels.

ISBN $905278194 X$

Trefw.: hartrevalidatie; Nederland; onderzoek. 


\title{
HARTREVALIDATIE IN NEDERLAND GEREGISTREERD EN GEËVALUEERD
}

\author{
Een inventariserend onderzoek naar \\ hartrevalidatie in Nederland
}

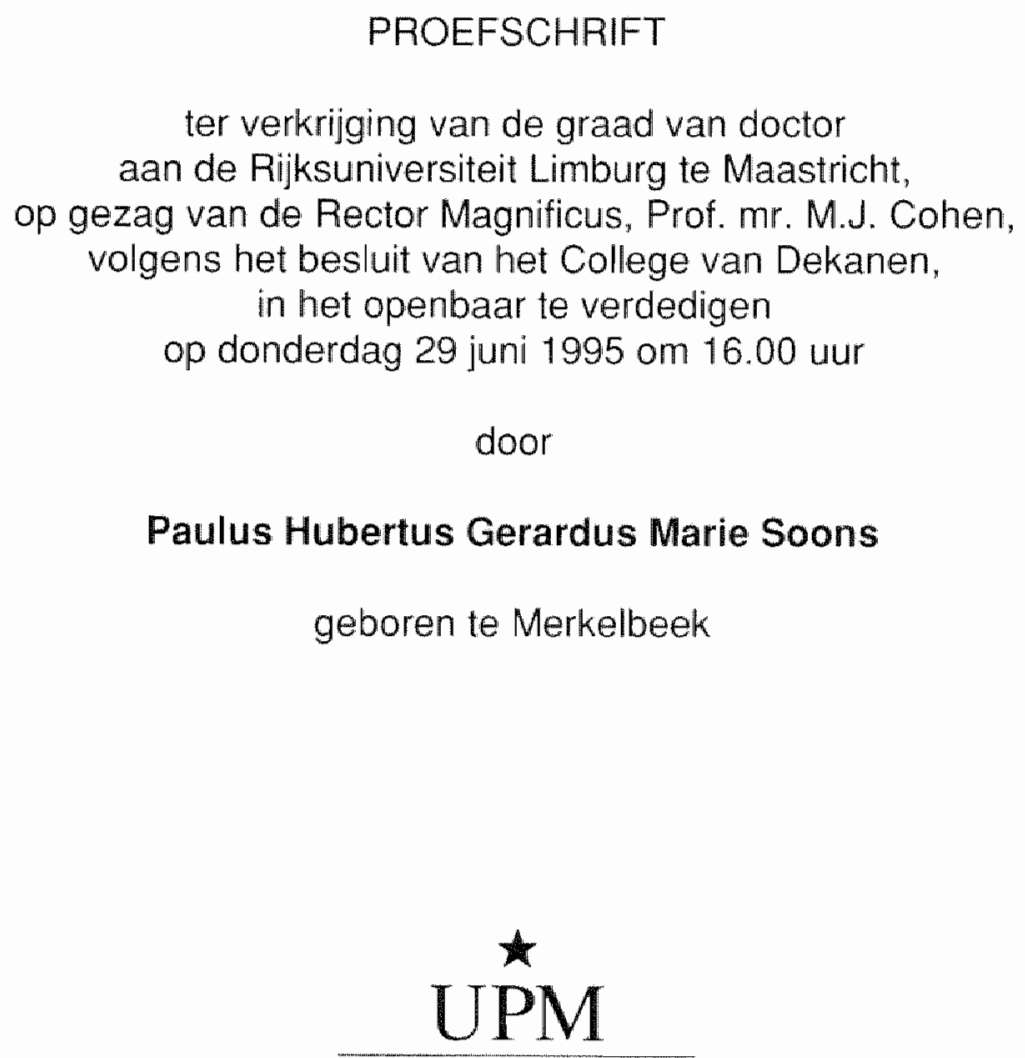

UNIVERSTAIRE PERS MAASTRICHT 


\section{Promotor:}

Prof.dr. H.J.J. Wellens

\section{Co-promotores:}

Dr. F.W.H.M. Bär

Dr. J.P.M. Diederiks

\section{Beoordelingscommissie:}

Prof.dr. A.P.W.M. Appels (voorzitter)

Dr. J.J. van Dixhoorn (arts, Amersfoort)

Prof.dr. C.M.J.G.Maes (Rijksuniversiteit Leiden)

Prof.dr. J.W. van Ree

Dr. C. de Zwaan 


\section{Inhoudsopgave}

\section{Hoofdstuk 1: INLEIDING EN PROBLEEMSTELLING}

1.1 Ontwikkelingen in de hartrevalidatie: algemeen 9

1.2 Hartrevalidatie in Nederland 11

1.3 Doelen hartrevalidatie 13

1.4 Fasen van hartrevalidatie 13

1.4.1 Fase 1: opname in het ziekenhuis 14

1.4.2 Fase 2: revalidatie na ontslag uit het ziekenhuis 14

1.4.3 Fase 3: nazorg 15

1.5 Revalidatiegeneeskunde en hartpatiënten 15

$\begin{array}{lll}1.6 & \text { Probleemstelling } & 16\end{array}$

$\begin{array}{lll}1.7 & \text { Het Registratieproject } & 17\end{array}$

$\begin{array}{lll}1.8 & \text { Hoofdstukindeling } & 18\end{array}$

Hoofdstuk 2: INVENTARISATIESTUDIES BETREFFENDE HARTREVALIDATIE IN BINNEN- EN BUITENLAND

$\begin{array}{lll}2.1 & \text { Inleiding } & 19\end{array}$

2.2 Nederland 19

2.2.1 Onderzoek naar aard en omvang van de zorg voor hartpatiënten 19

2.2.2 Onderzoek naar specifieke aspecten van de zorg voor hartpatiënten 23

2.2.3 Beschouwing over de hartrevalidatie in Nederland 26

$\begin{array}{lll}2.3 & \text { Europa } & 27\end{array}$

2.3.1 West-Duitsland 27

2.3.2 Engeland 30

2.3.3 Italië 31

2.3.4 Commentaar op studies uit Europa 32

$2.4 \quad$ Niet-Europese landen 33

2.4.1 Verenigde Staten 33

2.4.2 Canada 34

2.4.3 Australië 35

2.5 Discussie 37

2.5.1 Algemeen 37

2.5.2 Inhoudelijke beschouwingen 37

2.5.3 Methoden van onderzoek 39

2.5.4 Consequenties voor het eigen onderzoek 40

2.6 Conclusies 40 
Hoofdstuk 3: MOBILISATIE TIJDENS OPNAME IN HET ZIEKENHUIS

3.1 Inleiding

3.2 Vraagstelling 41

3.3 Methoden 41

3.4 Resultaten 42

3.4.1 Respons 42

3.4.2 Onderzoeksgegevens 42

3.5 Discussie 46

3.5.1 Dataverzameling en beperkingen 47

3.5 .2 Onderzoekspopulaties 48

3.5.3 Vergeliking van de resultaten van de twee onderzaeksmethoden 48

3.5.4 Beschouwingen 49

$\begin{array}{lll}3.6 & \text { Conclusies } & 51\end{array}$

\section{Hoofdstuk 4: REVALIDATIE NA ONTSLAG UIT HET ZIEKENHUIS}

4.1 Inleiding 53

4.2 Vraagstelling 53

4.3. Methoden $\quad 53$

4.4 Resultaten $\quad 54$

4.4.1 Respons

4.4.2 Onderzoeksgegevens $\quad 55$

4.5 Discussie 65

4.5.1 Onderzoekspopulaties 65

4.5.2 Dataverzameling en beperkingen 65

4.5.3 Vergelijking van de onderzoeksmethoden 65

4.5.4 Beschouwingen 67

4.6 Conclusies $\quad 72$

\section{Hoofdstuk 5: NAZORG}

$\begin{array}{lll}5.1 & \text { Inleiding } & 75\end{array}$

5.2 Vraagstelling $\quad 75$

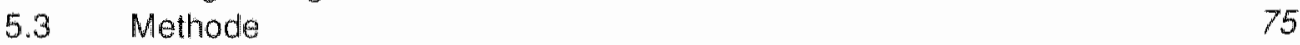

5.4 Resultaten $\quad 76$

5.4.1 Respons 76

5.4 .2 Onderzoeksgegevens 76

5.5 Discussie $\quad 83$

$\begin{array}{ll}5.5 .1 & \text { Dataverzameling } \\ 5.5 .2 & \text { Beschowwingen }\end{array}$

5.6 Conclusies $\quad 84$ 


\section{Hoofdstuk 6: ALGEMENE DISCUSSIE}

6.1 Inleiding 85

6.2 Evaluatie van de gebruikte methoden van onderzoek 85

6.3 Evaluatie van de revalidatie in Nederland 86

6.3.1 Opnamefase 86

6.3.2 Revalidatie na ontslag 88

6.3.3 Nazorg 92

6.4 Hoe verder? 93

$\begin{array}{lr}\text { Samenvatting } & 95\end{array}$

Summary 101

$\begin{array}{ll}\text { Literatuurlijst } & 107\end{array}$

Bijlage I: Enquête hartrevalidatie tijdens opname 115

Bijlage II: Individuele patiëntenregistratielijst hartrevalidatie tijdens opname en hartrevalidatie na ontslag uit het ziekenhuis 121

Bijlage III: Enquête hartrevalidatie na ontslag uit het ziekenhuis 129

Bijlage IV: Enquête nazorg hartpatiënten 135

$\begin{array}{ll}\text { Dankwoord } & 141\end{array}$

$\begin{array}{ll}\text { Curriculum vitae } & 143\end{array}$ 



\section{HOOFDSTUK 1}

\section{Inleiding en probleemstelling}

\subsection{ONTWIKKELINGEN IN DE HARTREVALIDATIE: ALGEMEEN}

Voor 1950 werd langdurige bedrust (zes weken) voor ce hartinfarctpatiënt noodzakelijk geacht, omdat de verlittekening van het necrotisch myocard tenminste zes weken zou vergen (Hellerstein, 1986). Een dergelijk beleid had grote terughoudendheid en zelfs angst voor inspanning tot gevolg. Deze visie impliceerde eveneens zeer beperkte toekomstperspectieven voor de patiënt. Een infarct resulteerde ondermeer bijna automatisch in arbeidsongeschiktheid.

Een kentering ontstond door twee ontwikkelingen: op de eerste plaats versnelden Levine en Lown (1951), omstreeks 1950, de mobilisatie door toepassing van "chair treatment" tijdens de herstelfase na een infarct. Tijdens een dergelijke behandeling bleken geen complicaties op te treden. Deze resultaten waren zowel fysiek als psychologisch gunstig voor de patiënt. Deze ontwikkeling was de start van fysieke reconditionering tijdens opname in het ziekenhuis.

De tweede ontwikkeling was dat de inspanningstolerantie bij hartpatiënten onderzocht werd om een eventuele arbeidsgeschiktheid te beoordelen. Hiertoe werden de zoge* naamde "work classification units" in de Verenigde Staten en later ook in Zweden en Australië opgezet (Dixhoorn van, 1990). In deze instellingen werd bepaald in welke mate een hartpatiënt weer kon gaan werken. Veel patiënten bleken in staat volwaardige arbeid te verrichten zonder extra ziekteverzuim, maar ook zonder extra risico's. Hiermee was de opvatting van langdurige immobilisatie en invaliditeit van hartinfarctpatiënten achterhaald.

Als vervolg hierop werden in de Verenigde Staten en Finland fysieke programma's ontwikkeld en succesvol toegepast. Doel was achteruitgang van de fysieke conditie, thromboëmbolieën en emotionele invaliditeit te beperken cq te voorkomen (Dixhoorn van, 1990). Door gunstige effecten van deze programma's op werkhervatting ontstond het idee om de fysieke capaciteit van de patiënt te vergroten door middel van expliciete trainingsprogramma's. Deze programma's vormden de aanzel voor de huidige hartrevalidatie na ontslag uit het ziekenhuis. In bovengenoemde ontwikkelingen lag de kiern voor de latere, eenzijdige gerichtheid ap fysieke reconditionering.

Indien er na de revalidatiefase nog fysieke en/of psychosociale problemen waren, of 
wanneer de patient de effecten van de revalidatie wilde bestendigen, kon deze middels een fysiek onderhoudsprogramma zijn revalidalie wervolgen (Denolin, 1985).

De grote nadruk op de inspanningsfysiologie en het niet tot ontwikkeling komen van de psychosociale zorg was kenmerkend woor de zestiger en zeventiger jaren. Het inspanningsfysiologisch onderzoek kon gerealiseerd worden dankzij nieuwe ontwikkelingen in de cardiologie: onder meer toepassing van ergometrie en ECG-monitoring, die bewaakte inspanning mogelik maakte. Het ergometrisch onderzoek kreeg een steeds centralere rol. Revalidatie was langzamerhand identiek geworden aan conditieverbetering. In deze periode ontstonden ook de eerste hartrevalidatiecentra in de USA, Finland, Zweden, Duitsland, Oostenrijk, Belgiè en Nederland. Deze kwamen mede tot stand door regelmatige bijeenkomsten van de Wereldgezondheidsraad met als doel hartrevalidatie ook in Europa te propageren. De WHO zorgde voor hel verzamelen van know-how (MHO, 1964 en 1967) en gaf aanbevelingen omtrent de inhoudelike vormgeving van revalidatie programma's. Hartrevalidatie diende zowel fysieke aspecten (WHO, 1968), als psychosociale onderdelen (WHO, 1970) te bevatten. Van dat laatste kwam in de praktijk echter weinig terecht. Op papier werd het belang van psychologische aspecten hoog ingeschat (Gentry \& Willams, 1975; Stocksmeier, 1976; König, 1976).

Dankzij het herkennen van de risicofactoren voor het krijgen van coronarialijden werd langzamerhand de waarde van secundaire preventie herkend (Hellerstein, 1986). Tijdens de revalidatie werd in beperkte mate aandacht besteed aan de verandering van deze risicofactoren. Ze richtte zich onder meer op roken, hypercholesterolemie, hypertensie en gebrek aan bewegen.

Rond 1980 was reconditionering in de ziekenhuisfase in de meeste ziekenhuizen een geaccepteerde therapie. Ook omtrent fysieke reconditionering na de ziekenhuisfase bestond redelijke consensus. Een multidisciplinaire aanpak, psychosociale zorg en de systematisch toepassing van secundaire preventie kwam echter nog steeds weinig voor. De noodzaak ervan werd, in ieder geval theoretisch, wel ingezien (Denolin, 1985).

Naast de inhoudelijke aanpak van hartrevalidatie is belangrijk hoe revalidatie-activiteiten betreffende revalidatie na ontslag uit het ziekenhuis georganiseerd moeten worden. Dit is vooral een probleem omdat hiervoor, in tegenstelling tot de revalidatie tijdens de opneme, aparte organisatorische eenheden gecreëerd dienden te worden, die relatief kostbaar zijn.

In sommige landen gaan de patienten vanuit het ziekenhuis van opname direct door naar een gespecialiseerd (klinisch) revalidatiecentrum, andere landen prefereren een minder formeel poliklinisch revalidatieprogramma in het ziekenhuis van opname (Cantwell, 1979). Bovendien bestaat een combinatie van deze twee mogelijkheden: een deel van de patiënten wordt doorgestuurd naar een revalidatiecentrum voor klinische revalidatie en een ander deel voor poliklinische revalidatie. Per land of regio bestaat er een enorme variatie aan revalidatiefaciliteiten, met aan het ene uiterste klinische revalidatie in een revalidatiecentrum en aan hel andere uiterste fysieke oefeningen voor thuis met geen of weinig controlemogelijkheden. Totaal onduidelijk is hoe activiteiten van patientenver- 
enigingen na afloop van de revalidatie georganiseerd zouden moeten worden (Denolin, 1985).

In de tachtiger jaren wordt dan ook, vanwege de inhoudelike en organisatorische onduidelikheden, steeds vaker de vraag gesteld: "hoe moeten we nu verder met hartrevalidatie?". De hartrevalidatie zit in een impasse! Idealiter zou per individuele patiënt bekeken moeten worden of de patiënt revalidatie nodig heeft en welk revalida tieprogramma het meest geschikt is. Als consequentie hiervan zou de organisatie van de hartrevalidatie hieraan aangepast moeten worden. Standaard programma's, zoals nu gangbaar zijn, gericht op groepen zouden dan niet meer voldoen (Verkley, 1982 ; Meyer. 1985; Wenger, 1987; Erdman \& Dixhoorn van, 1987; Erdman \& Weeda, 1989 .

\subsection{HARTREVALIDATIE IN NEDERLAND}

In het navolgende wordt een beeld geschetst van het gevoerde beleid door de Nederlandse Hartstichting en de overheid ten aanzien wan hartrevalidatie.

Op 18 mei 1965 werd door de Nederlandse Hartstichting de Revalidatie Commissle opgericht. Een jaar later resulteerde dit in een rapport getiteld "Revalidatie van de hartpatiënt" (NHS, 1966; Bonjer, 1968; Straten van, 1968), waarin aanbevelingen gedaan werden om hartrevalidatie in Nederland van de grond te krijgen. Het hoofddoel was de kans op werkhervatting te verbeteren. De wolgende behandelonderdelen werden aanbevolen: fysieke reconditionering, psychische reconditionering, ergometrie ter meting van het resterend arbeidsvermogen en voorbereiding op werkhervatting. Revalidatie na ontslag zou geconcentreerd moeten worden in een beperkt aantal gespecialiseerde. regionaal opererende hartrevalidatiecentra. Revalidatie na ontslag was geindiceerd voor patiënten met een middelzwaar infarct, patiënten met een discrepantie tussen subjectieve klachten en objectieve bevindingen, en ongeschoolde hartpatiënten van middelba* re leeftijd. Revalidatie werd ongeschikt geacht voor patiënten die zonder meer weer aan het werk konden en voor patiënten die arbeidsongeschikt waren.

Na een studiereis van de Revalidatie Commissie naar Scandinavië ging de hartrevalidatie na ontslag uit het ziekenhuis in 1970 officieel van start in 5 centra (NHS, 1969): Academisch Ziekenhuis Leiden/Zeehospitium Katwijk. St. Antonius Ziekenhuis Nieuwegein, Academisch Ziekenhuis Groningen/Beatrixoord Haren, Wilhelmina Gasthuss Amsterdam/Revalidatie Instituut Muiderpoort en Ziekenhuis Ziekenzorg Enschede. Na gunstige ervaringen in het eerste proefjaar werden overeenkomsten met de ziekentondsen aangegaan, zodat er een gezonde financiële basis ontstond om deze activiteiten voort te zetten (Weeda \& Visser, 1981). De verdere uitbreiding van de hartrevalidatie verliep geleidelijk (Meijler, 1973; Verstappen ea, 1974: Meiberg-Schutte \& Meijler, 1975; Kazemier, 1979; Dam van \& Boer, 1985; Vries de, 1985). De overheid voerde in 1974 een erkenningenbeleid in met de bedoeling een adequate regionale spreiding van 
voorzieningen te bewerkstelligen (Vos, 1978). Erkende afdelingen dienden een poliklinisch, multidisciplinair revalidatie programma aan te bieden.

In 1977 verscheen het tweede rapport van de Revalidatie Commissie (NHS, 1977 ), de 5 bovengenoemde projecten werden geëwalueerd. Doel van de revalidatie diende niet alleen werkhervatting te zijn. maar ook andere aspecten die voor de patient in zijn dagelijks leefpatroon van belang waren behoorden onderwerp van hulpverlening te zijn. Verder was revalidatie een belangrijk middel gebleken om een hartpatiënt in fysiek en psychosociaal opzlcht tot optimaal functioneren te brengen. Revalidatie na ontslag uit het ziekentisuis diende voor alle patienten, voor wie dat nuttig bleek, beschikbaar te komen. Precieze indicatie-criteria werden niet geformuleerd. Psychosociale zorg werd van groot belang geacht. De huipverleners die hiervoor het meest in aanmerking kwamen waren de maatschappelijk werker, de klinisch psycholoog en soms de psychiater. Er werden enkele instrumenten aambevolen voor diagnostiek en indicatiestelling op dit terrein. Als behandelingsmogeijkhedien werden aanbevolen: crisisinterventie, counselingsgesprekken en psychotherapie. Psychosociale zorg diende gericht te zijn op het individu (de patiënt), het echtpaar/gezin en de werksituatie. Betreffende de organisatie van hartrevalidatie thinkte de Commissie op twee gedachten: aan de ene kant bestond er een voorkeur voor gespecialiseerde centra en aan de andere kant vond men dat in principe ieder ziekenhuis zijn eigen revalidatie moest kunnen geven.

In de praktijk werkte het erkenningenbeleid van de overheid dat gericht was op regionale concentratie niet: patienten werden niet of onvoldoende doorverwezen en vaak was de wachttijd te lang (Weeda \& Visser, 1981). Deze ervaringen waren voor de Revalidatie Commissie aanleiding haar beleid te wijzigen; in 1981 was de Commissie van mening dat ieder ziekenhuis zijn eigen patiënten diende te revalideren (Weeda \& Visser, 1981) met als gevolg dat het erkenningenbeleid wan de overheid hieraan aangepast diende te worden. Dit is echter niet gebeurd, waardoor er een impasse is opgetreden in de revalidatie: een multidisciplinaire aanpak en met name ook de psychosociale zorg is mede hierdoor onvoldoende tot ontwikkeling gekomen.

Ondertussen nam het aantal afdelingen met alleen fysieke reconditionering aanzienlijk toe, vooral omdat hiervoor een aparte tariefstelling was geregeld. Een andere ontwikkeling was dat secundaire preventie gericht op verandering van risicogedrag, althans op papier, steeds belangrijker gevonden werd (Weeda, 1981).

In 1984 kwam een derde rapport uit (NHS, 1984). De belangrijkste motieven om dit rapport te schrijven warem: het stagnerend erkenningenbeleid, thet onvoldoende beschikbaar zijn van revalidatievoorzieningen voor hartpatiënten en het ontbreken van eenstemmigheid over de waarde van hartrevalidatie. Enkele conclusies: voor de meeste patiënten leek reconditionerende fysiotherapie, met als nieuwe factor dat dit kon geschieden in groepsverband, en zonodig begeleiding door maatschappelijk werk, voldoende te zijn. Verder werd ingegaan op de indicatiestelling voor poliklinische hartrevalidatie. Het rapport gaf de volgende indicaties aan: hartinfarct, hartoperatie, lichtere vormen van 
angina pectoris, die niet gunstig reagleerden op de gebruikelike behandeling , hartangst, somatisering en onvoldoende zelfvertrouwen.

Medische contra-indicaties waren: ernstige ritmestoornissen, geleidingsstoomissen, ernstige angina pectoris en pompfunctiestoornissen, kortom de cardiaal hogere risico. groep. Ook niet-cardiale aandoeningen die een ongunstige invloed uitoetenen op de lichamelijke conditie zoals sommige longaandoeningen, werden uitgesloten.

Psychosociale contra-indicaties werden eveneens genoemd: gebrek aan motivatie en ernstige psychopathologie. Anno 1990 waren de problemen in de hartrevalidatie in grote lijnen hetzelfde (NHS, 1990).

Samenvattend: er is sprake van een impasse betreffende de manier waarop revalidatie georganiseerd moet worden. Op de tweede plaats is op papier duidelijk welke onderdelen revalidatie dient te bevatten, maar in de prakijk is er geen sprake van een adequate realisering. Op de derde plaats zijn de indicatiecriteria veel te onnauwkeurig omschrever.

\subsection{DOELEN HARTREVALIDATIE}

In de zorg voor hartpatiënten is, naast medische zorg, revalidatie van groot belang. De doelstellingen van hartrevalidatie zijn tweeledig (Denolin, 1985; NHS, 1990):

(a) Het terugbrengen van de patiënt naar zijn vroegere toestand, in fysiek, sociaal en psychologisch opzicht, afhankelijk van de beperkingen als gevolg van het incident en

(b) De beinvloeding van de factoren die hebben bijgedragen tot het ontstaan van de hartaandioening, de zogenaamde risicofactoren, zoals verkeerde voeding, roken, hypertensie, gebrek aan beweging, stress, persoonlijkheidsstructuur (Appels, 1983). Het gaat hier om secundaire preventie ter voorkoming van recidieven of uitbreiding van de reeds aanwezige aandoening.

Pre-morbide ziekten en psychosociale problematiek cq psychopathologie zijn geen direct onderdeel van hartrevalidatie. Genoemde doelstellingen van revalidatie hebben in de verschillende fasen van hel zorgtraject een ander gewicht, zoals beschreven zal worden in paragraaf 1.4 .

\subsection{FASEN VAN HARTREVALIDATIE}

Het hartrevalidatieproces bestaal uit drie fasen (NHS, 1966; Wilson e.a, 1979; Denolin; 1985; NHS, 1990). Deze fasering komt ook tot uitdrukking in de organisatie van de hartrevalidatie. Het gaal om de revalidatie tijdens opname in het ziekenhuis (fase 1), de revalidatie na ontslag uit het ziekenhuis (fase 2) en de nazorgfase (fase 3), die buiten de institutionele gezondheidszorg valt. Uiteraard is deze indeling globaal, de verschillende fasen lopen in elkaar over. Dit geldt met name voor lase 2 en 3. 


\subsubsection{Fase 1: opname in het ziekenhuis}

(a) De acute fase: voor intarctpatiënten betreft dat de tijd op de Coronary Care Unit en woor operatiepatienten de ijj op de Intensive Care. Deze fase duurt meestal enkele dagen. Tijdens deze fase is het hoofddoel de patiënt in leven te houden en medische complicaties te voorkomen cq op te vangen. Normaliter vindt tijdens deze fase al een stuk passieve mobilisatte plaats, dat in de subacute fase gevolgd wordt door actieve mobilisatie. Herbij zijn zowel verpleegkundigen als fysiotherapeuten betrokken.

(b) De subacute fase: dit is de periode waarin de patient op de verpleegafdeling of medium care ligt. Deze tase duurt gemiddeld 5 tot 14 dagen. Dan wordt in de meeste ziekenhuizen gestart mel actieve mobilisatie van de patiënt, die erop gericht is om tenminste het Activities of Daily Living ( $A D L$ )-niveau te bereiken, variërend van aankleden tot traplopen. Meestal kunnen de patiènten echter veel meer. Daamaast vindt er zonodig onderzoek plaats naar risicofactoren. Vervolgens wordt voorlichting gegeven door arts en/of verpleging. Sporadisch zal een consult van klinisch psycholoog of maatschappelijk werker nodig zijn.

Rond het onlstag wordt vaak een inspanningstest gedaan (met name bij infarctpatiënten) om high risk patiènten te selecteren. Indien geindiceerd zal hartcatheterisatie plaatswinden en daarna zonodig operatie of PTCA.

\subsubsection{Fase 2: revalidatie na ontslag uit het ziekenhuis}

Dit is de eerste periode na ontslag uit het ziekenhuis. Deze fase duurt ongeveer 3 maanden. In deze periode krijgen vele patiënten hartrevalidatie. Een naar schatting beperkt aantal patiënten kan, vanwege de beperkte fysieke mogelijkheden, niet deelnemen aan een dergelijk revalidatie programma, een aantal mag dat niet vanwege te grote cardiale risico's en een aantal wil niet. De revalidatie dient in deze fase allereerst gericht te zijn op herstel van de pre-morbide situatie. Dit kan bereikt worden door het opbouwen van de conditie en verwerking van het incident. Daarnaast is revalidatie gericht op verandering van levensstijl waarbij risicovolle gedragingen zoals roken aangepakt worden (secundaire preventie). Tenslatte dient revalidatie benut te worden als voorbereiding op werkhervatting of zonodig afkeuring. Ten behoeve van werkproblematiek zijn instanties als GAK, GMD en bedrijtsarts actiet. Met andere woorden "het doel van de revalidatie is om fysiek, psychisch en sociaal zoveel mogelijk weer het prémorbide niveau te bereiken.

In de praktijk zijn er drie vormen waarin hartrevalidatie na ontslag gegeven wordl: klinische revalidatie, revalidatiedagbehandeling en fysieke reconditionering. Een vierde vorm, namelijk fysiotherapie in particuliere praktijken, heeft alleen in experimentele vorm bestaan. Het is nooit een aparte vorm van revalidatie geworden (KNGF, 1990; Bär \& Vonken, 1990).

\subsubsection{Fase 3: nazorg}

Deze fase, de onderhouds- of resocialisatiefase, volgt op de eventuele hartrevalidatie van fase 2. Kenmerkend voor deze fase is dat de patiënt. los van ziekenhuis of 
revalidatieafdeling, zijn resocialisatie vervolgt. Dit houd in dat hij weer zoveel mogelijk zijn normale leven oppakt in het gezin, dit geldt ook voor zijn bezigheden, hobbies en werk. Op de tweede plaats dient deze fase om de in gang gezette verandering van levensstili te bestendigen (Miller ea, 1979). De patient blift in deze fase doorgaans onder controle van de cardioloog. Ook de huisarts begeleidt de patiënt. Overigens is het contact met de huisarts als herkenbare figuur en vaste begeleider ook in eerdere fasen van de revalidatie van grote waarde woor de patient.

Voor problemen op het vlak van uitkeringen en eventuele werkhervatting zijn instanties als GAK, GMD en de bedrijfsarts van belang. Doorgaans bestaat al snel na de start van de revalidatie contact tussen patiënt en deze instanties. Bij belangrijke psychosociale problematiek die onvoldoende is afgerond tijdens de revalidatie fase kan de patiënt voor verdere begeleiding doorgestuurd worden naar het Algemeen Maatschappelijk Werk, het RIAGG, de psychiatrische polikliniek of andere instanties. Er worden in deze fase nogal wat activiteiten specifiek ten behoeve van de hartpatiënten georganiseerd zoals: sportgroepen voor hartpatiënten en psychosociale groepsbegleleiding.

\subsection{REVALIDATIEGENEESKUNDE EN HARTPATIËNTEN}

Revalidatie is volgens de World Health Organization (WHO, 1969) het gecoördineerd en gecombineerd gebruik van maatregelen op medisch, paramedisch, sociaal "arbeidstechnisch en onderwijskundig terrein, die de gehandicapte op de voor hem optimale plaats in de maatschappii moet brengen en houden. De revalidatiegeneeskunde is dat deel van de geneeskunde dat zich richt op het zo viroeg mogelijk onderkennen en behandelen van organische functiestoomissen en de daardoor veroorzaakte (dreigende) beperkin. gen met de eventueel daaruit weer voortwloeiende sociale consequenties, de handicap (Bangma, 1988).

In de revalidatie geneeskunde wordt de "International Classification of impairment, Disability and Handicap" van de World Health Organization gebruikt (TNO, 1981). In het navolgende zal deze terminologie toegespitst worden op hartpatiënten:

(a) Functiestoornis: elk lichamelijk verlies of afname van functies. Bij cardiate ziekten kan er bijvoorbeeld sprake zijn van een atgenomen pomptunctie van het hart.

(b) Beperkingen: elke vermindering of afwezigheid van de vaardigheid een activiteit uit te voeren, die van iemand van een bepaalde leeftij. geslacht en cultuur verwacht had mogen worden. Deze beperkingen kunnen volledig bepaald worden door de functiestoor nis, maar ze kunnen ook veroorzaakt worden door de psychische reactie van patiënt op zijn ziekte. Bij hartziekten kunnen we bijvoorbeeld te maken hebben met beperkingen in loopatstand, traplopen of hel verrichten van handarbeid ten gevolge van pompfunctiestoornissen of angina pectoris. Anderzijds kunnen ook angsten ten gevolge van een hartinfarct deze beperkingen veroorzaken.

(c) Handicap: de nadelige sociale positie ten gevolge van een functiestoornis of beperking waardoor een normale vervulling van zijn of haar maatschappelike rol beperkt of verhinderd wordt. Bij hartzlikten hebben we onder meer te maken met handicaps in de zin van gestoord functioneren bij de arbeid en/of in de rol als partner. Daarnaast kunnen 
er handicaps zijn op het gebied van vrijetijdsbesteding, zelfstandig wonen, huishouding. vervoer enz.

Revalidatie richt zich doorgaans op motorisch gehandicapten. Het aantal hartpatiënten met mótorische functiestoornissen is beperkt. Hartrevalidatie is dan in principe gericht op de beperkingen en handicaps niet direct ontstaan door het hartlijden, maar slechts indirect door bijvoorbeeld extreme angst (Weeda, 1983; Bangma, 1986 en 1987).

Het revalidatiemodel dient duidelijk onderscheiden te worden van het medisch model. Het medisch model beoogt primalr morbiditeit en mortaliteit te beinvloeden. Deze invalshoek is gericht op de somatische stoornis. Het zijn met name de cardioloog en cardiochirurg bijgestaan door verpleegkundigen die op dit vlak werkzaam zijn. Het revalidatiemodel (revalidatie in brede zin) is primair gericht op het optimaal functioneren van de patiént in de meest brede zin. Deze invalshoek is gericht op de beperkingen en handicaps van de hartpatiënt. De hulpverleners die op dit vlak werkzaam zijn, zijn Iysiotherapeut, revalidatiearts (revalidatiezorg in engere zin), maatschappelijk werker. ergotherapeut en klinisch psycholoog. Beide modellen zijn complementair in de zorg voor hartpatiënten (Weeda, 1983; Bangma, 1988). In elke fase van het zorgproces nemen beide benaderingen een verschillende plaats in.

\subsection{PROBLEEMSTELLING}

Hartrevalidatie heeft zich, ook in Nederland, divers ontwikkeld. Er zijn geen eenduidige richtlijnen hoe revalidatie aan te pakken. Hartrevalidatle zit op een aantal gebieden in een impasse: er zijn diverse regelingen volgens welke hartrevalidatie gefinancierd wordt, er is een diversiteit aan instellingen die hartrevalidatie geven, er is een veelvoud van opvattingen hoe hartrevalidatie er inhoudelijk uit moel zien, en er is discussie welke patiënten wel en welke patiënten niet daadwerkelijk gerevalideerd dienen te worden en hoe effectlef dit is.

Er is in de relatief korte historie van hartrevalidatie sprake van een reeks initiatieven, die deels op lokaal niveau en deels via de overheid tot stand gekomen zijn. De overheid heeft zich beziggehouden met de financiering. Ook de Nederlandse Hartstichting heeft zowel beleidsmatig als inhoudelijk bijgedragen aan de ontwikkeling van de hartrevalidatie. Daar komt nog bij dat het gevoerde beleid niet altijd eenduidig is geweest, mede door de omstandigheid dat effectstudies het effect van revalidatie activiteiten nog lang niet eenduidig hebben aangetoond.

De eerste doelstelling van deze dissertatie is te inwentariseren hoe de hartrevalidatie in Nederland zich door de jaren heen in kwantitatief opzicht ontwikkeld heeft. De volgende vragen staan op de voorgrond:

(a) Hoeveel instellingen geven revalidatie activiteiten voor hartpatienten? Welke soorten instellingen zijn er en hoe worden deze gefinancierd? Hoe is hun geografische spreiding over het land? Wanneer zijn ze gestart met revalideren? Zijn er ontwikkelingen in de tijd waaneembaar? 
(b) Weke patiënten worden in de praktik gerevalideerd en welke niet? Zijn er ontwikkelingen door de jaren heen te signaleren?

(c) Welke behandelonderdelen worden er gegewen, welke disciplines werken er mee? Zijn er ontwikkelingen te zien door de jaren heen?

De tweede doelstelling van deze dissertatie is te onderzoeken of de leizelike gang van zaken in de revalidatie in overeenstemming is met de officiele regels die hiervoor gesteld worden op zowel inhoudelikk als organisatorisch gebied. De gevonden ciffers en ontwikkelingen zullen worden affgezet en besproken tegen het licht wan de volgende facetten: (a) In welke mate voldoet de hartrevalidatie zoals deze zich heeft ontwikkeld in Nederland aan de doelstellingen van hartrevalidatie zoals door de WHO opgesteld? (b) Hoe verhoudt de concrete gang van zaken in de hartrevalidatie zich tot de revalidatiegeneeskundige opvattingen omtrent de revalidatie van hartpatiënten?

(c) In welke mate voldoet de hartrevalidatie in de praktijk aan de regels en aanbevelingen van de overheid en de Nederlandse Hartstichting?

(d) Hoe verhouden zich de ontwikkelingen in Nederland tot die in het buitenland. Zijn er overeenkomsten en/of verschillen? Loopt de revalidatie in Nederland voor op het buitenland of achter? Hiertoe is een literatuuronderzoek gedaan.

Samenvattend kan gesteld worden dat de pretentie wan dit onderzoek is om allereerst een zo compleet mogelijke beschrijuing te geven van de stand van zaken in de hartrevalidatie in Nederland, die vervolgens geconfronteerd wordt met het gevoerde beleid op dit gebied. Op de derde plaats wordt de Nederlandse situatie vergeleken met die in het buitenland.

\subsection{HET REGISTRATIEPROJECT}

"Het Registratieproject" is door de Revalidatie Commissie van de Nederlandse Hartstichting geëntameerd om op grond van genoemde probleemstelling een kwantitatieve inventarisatie te maken van alle hartrevalidatie activiteiten in Nederland. Vervolgens kan hiermee het gevoerde beleid geëvalueerd worden. Het project is gestart in 1987 en in 1991 is gestopt met de onderzoekingen.

Naast de genoemde doelstellingen werd het ook belangrijk gevonden het beleid op instellingsniveau te beïnvloeden: met behulp van de door de instellingen, middels de schriftelijke enquête, verstrekte gegevens werd via het project een jaarverslag per instelling gemaakt. Tevens werd een verslag gemaakt van alle instellingen tezamen, waardoor de instellingen zichzelf konden vergelijken met het gemiddelde. Verder is er een computerprogramma ontwikkeld waarbij de instellingen, die deze patiëntengegevens bijhielden, nauwkeuriger inzicht hadden in de gegevens op individueel patiëntenniveau, maar ook in staat waren computeruitdraaien en tellingen van hun patiëntenbestand te maken. Tevens was het mogelïk om met behulp van de zelf ingevoerde gegevens een patiëntenbrief samen te stellen (Soons ea, 1989). 
De volgende onderzoeksactwiteiten hebben in het kader van "Het Registratieproject" plaatsgevonden in de periode 1987 tof 1991 :

(a) In de periode $1987-1989$ hebben diverse enquêteringen plaatsgevonden betrettende de tase na ontslag (Soons \& Bär, 1990a en b; Soons "1993).

(b) Hieraan werd in $1987 / 88$ een mondelinge enquete aan de instellingen die hartrevalidatie na ontslag gaven toegevoegd om de kwalteit van de verkregen gegevens te verbeteren en te completeren.

(c) In 1989 is tevens een enquete rondgestuurd om gegevens te verkrijgen betreffende de ziekenhuistase.

(d) De nazorgtase is in 1990 onderzocht.

De nadruk van bovengenoemde enquêtes lag steeds op het inventariseren van kenmerken van de instellingen en hun programmaonderdelen; in beperkte mate kwamen ook patiêntkenmerken aan bod.

(e) In de periode 1988-1991 zijn door een deel van de instellingen die revalidalie tijdens opname en/of na ontslag uit het ziekenhuis gaven, individuele patiëntengegevens verzameld (Soons ea, 1989), middels de individuele patiëntenregistratielijst.

Een groot deel van de data die middels bovengenoemde onderzoeksinspanningen zijn verzameld, zijn gebrukt voor deze dissertatie.

\subsection{HOOFDSTUKINDELING}

In hoofdstuk 2 wordt verslag gedaan van een literatuuronderzoek betreffende inventarisatie-onderzoeken naar de stand van zaken van hartrevalidatie in zowel binnen-als buitenland. De balans van de stand van zaken in Nederland zal worden opgemaakt. Deze zall vergeleken worden met de situatie in het buitenlland. Hoofdstuk 3 betreft revalidatie in de ziekenhuisfase. Hierin worden resultaten van zowel een schriftelijke enquête, als van individuele patiëntenlijsten gepresenteerd. Hoofdstuk 4 betreft de revalidatie na ontslag uit het ziekentuis. Hierin worden de resultaten van enkele enquêtes en van individuele patiëntenlijsten gepresenteerd. In hoofdstuk 5 worden de resultaten van de enquête betreffende de nazorgfase beschreven. In de hoofdstukken 3, 4 en 5 wordt een kwantitatief beeld geschetst van de stand van zaken van de hartrevalidatie in Nederland. In hoofdstuk 6 zullen ontwikkelingen gesignaleerd worden. Tevens zullen de cijfers en ontwikkelingen kritisch besproken worden in hel licht van het gevoerde beleid. Daarnaast zullen de ontwikkelingen geëvalueerd worden aan de hand van bestaande definities wan hartrevalidatie. Tot slot zullen aambevelingen gegeven worden voor de toekomst van de hartrewalidatie in Nederland. 


\section{HOOFDSTUK 2}

\section{Inventarisatiestudies betreffende hartrevalidatie in binnen- en buitenland}

\subsection{INLEIDING}

Doel van dit onderzoek is het in kaart brengen van de resultaten van inventarisatie studies betreffende hartrevalidatie in binnen- en buitenland. Het gehele zorgtraject in drie fasen. dat een hartpatiënt kan afleggen, komt aan bod: de mobilisatie tijdens de opname, de revalidatie na ontslag en de nazorg. Ook zal nagegaan worden welke onderzoeksmethoden zijn gebruikt. Hiertoe zijn de volgende bronnen geraadpleegd: de Index Medicus, de bibliotheek van de Nederlandse Hartstichting en een rondschrijven aam hartstichtingem in het buitenland.

\subsection{NEDERLAND}

\subsubsection{Onderzoek naar aard en omvang van de zorg voor hartpatiënten}

\section{Onderzoek I}

In 1979 is, op verzoek van de Revalidatie Commissie van de Nederlandse Hartstichting. een inventariserend anderzoek gedaan naar de revalidatie van hartpatiënten in Nederland (Weeda \& Visser, 1981; Aquarius \& Smit, 1980). Het betrof zowel hartrevalidatie tijdens opname in het ziekenhuis, als na ontslag.

Er werden vragenlijsten gestuurd naar cardiologen, hoolden van hartbewakingseenheden en fysiotherapeuten van alle ziekenhuizen met een hartbewakingseenheid: 98 van de 140 aangeschreven ziekenthuizen $(70 \%$ ) reageerden (zie tabel 1).

In de meeste ziekenhuizen werd tijdens opname na een hartinfarct of een hartoperatie aandacht besteed aan actieve mobilisatie, reactivering en Activities of Daily Living (ADL) - training. De helft van de ziekenhuizen zette hiervoor fysiotherapeuten in, de rest verpleegkundigen. Ten behoeve van de protessionele psychosociale zorg waren in de 
helft van de ziekenhuizen maatschappelik werkers beschikbaar en in sommige klinisch psychologen.

Bina de helft van de ziekenhuizen bood poliklinische revalidatie aan; hievan hadden er twintig een erkenning voor revalidatiedagbehandeling van hartpatienten. Drie instellingen gaven Klinische revalidatie na ontslag. In 1974 telde Nederland ongeveer 20 atdelingen, waarvan de helt ekkenning had.

De hiema gepresenteerde gegevens hebben allemaal betrekking op de poliklinische hartrevalidatie. Er bleek een grote variëteit te bestaan in beschikbare disciplines, zoals duidelijk werd uit gegevens van 46 centra die poliklinische zorg aanboden. De meest voorkomende hulpverleners waren: fysiotherapeut $(93 \%)$, cardioloog (70\%), maatschappelijk werker $(67 \%)$, kinisch psycholoog $(46 \%)$, revalidatiearts $(24 \%)$, diëtiste $(24 \%)$ en internist (15\%).

De patiênten kregen in alle ziekenhuizen een fyslek trainingsprogramma aangeboden. Duur en opbouw vam het fysieke programma in de poliklinische tase toonden een grote verscheidenheid. De gemiddelde duur was 16 weken, met een variatie van 8 tot meer dan 28 weken. Het gemiddeld aantal sessies bedroeg 33 , met een variatie van 20 tot 50. Verder bleek hartrevalidatie in 1979 meestal pas drie lot acht weken na ontslag uit het ziekenhuis te beginnen. Slechts in een kwart van de gevallen werd binnen twee weken gestart.

Psychosociale zorg werd in de helft van de programma's verstrekt op indicatie; in de andere helft kreeg ledere patiënt deze hulp aangeboden. Individuele psychosaciale zorg was in vrijwel alle instellingen mogelijk. In eenderde van de instellingen vond ook begeleiding in groepen plaats, waarbij onduidelijk blijt hoe deze groepen werden opgezet. Psychosociale zorg werd voornamelijk gegeven door de maatschappelijk werker, die in bijna alle instellingen betrokken was bij de hartrevalidatie. Daarnaast waren in de helft van de instellingen de klinisch psycholoog en in mindere mate de wijkverpleeg. kundige en de revalidatiearts beschikbaar voor psychosociale zorg.

In bijna alle 46 op dit pumt responderende ziekenhuizen werden patiënten zowel na een hartinfarct als na een hartoperatie gerevalideerd, terwijl in ruim de helft van de ziekenhuizen ook patienten met angina pectoris gerevalideerd werden. De aandacht ging toen nog sterk uil naar werkherwatting, zoals impliciet blijkt uit hel leeftijdscriterium: $4 \%$ accepteerde geen patienten ouder dan 50 jaar, $12 \%$ legde de grens bij 60 jaar, $52 \%$ bij 65 jaar en $2 \%$ bij 70 jaar, $30 \%$ van de instellingen hanteerde geen leeftijdsgrens.

\section{Onderzoek II}

In: 1984 werd de hiervoor beschreven inventarisatie door Van Dixhoorn ea (1988) herhaald en uitgebreid (zie tabel 1). Bij dit onderzoek was overigens alleen hartrevalidatie na ontslag uit het ziekenhuis onderwerp van onderzoek. In de regio's Noord-Oost, West en Zuid-Nederland werden, voor vertegenwoordigers van de toen bekende hartrevalidatieinstellingen, regionale bijeenkomsten georganiseerd, waarop aan de bezoekers (cardiologen, verpleegkundigen en fysiotherapeuteny gevraagd werd een schriftelijke enquète in te vullen die, ten opzichte van 1979, op een aantal punten verbeterd was. De niet-aarwezigen kregen de enquête toegestuurd. De respons was zeer hoog en bedroeg 
$97 \%$ (zie tabel 1) (36 van de 89 instellingen). 27 van deze 89 afdelingen hadden een erkenning voor revalidatiedagbehandeling.

De landelijke spreiding zag er in 1984 als volgt uit: in de regio West (Randstad tot en met de Veluwe) waren 33 (12 erkend), in de regio Zuid (provincies Zeeland, Brabant en Limburg) 35 (10 erkend) en tenslotte in de regio Noord-Oost 21 atdelingen (5 erkend).

De betrokken anderzoekers hebben de gegevens van de klinische en poliklinische revalidatie bij het verwerken niet gescheiden gehouden. Uit de gegevens van de 86 reagerende centra bleek de betrokkenheid van de verschillende disciplines bij de revalidatie: fysiotherapeut $(9 \% \%)$, cardioloog (72\%), maatschappelik werker (72\%), klinisch psycholoog $(59 \%)$, diëtiste $(41 \%)$, arts $(40 \%)$, verpleegkundige $(23 \%)$, In erkende atdelingen waren meer disciplines beschkbaar dan in niet-erkende. Regelmatig teamoverleg vond tenminste eenmaal per twee weken plaats in alle erkende afdelingen; en in slechts $45 \%$ van de nietwerkende.

ledere instelling bood een fysiotherapieprogramma aan. Het fysieke programma startte in 1984 al tussen de twee en drie weken na ontslag (in 1979 nog drie tot acht weken): de helft begon zelfs binnen twee weken na ontslag. Wel variëerde het fysieke programma in hoge mate in duur ( 3 tot 25 weken, gemiddeld 12 à 13 weken), aantal bijeenkomsten (tot maximaal 50 sessies, gemiddeld 28 sessles) en inhoud.

Psychosociale zorg (individueel en/of groepsgewijs) werd in $96 \%$ van de erkende en in $59 \%$ van de niet-erkende afdelingen gegeven, hetgeen natuurlijk samenhangt met de financiering.

Individuele begeleiding vond plaats bij $37 \%$ van de erkende afdelingen en bij $22 \%$ van de niet erkende afdelingen. Een kwart van de ziekenhuizen bood groepsgewijze psychosociale zorg aan ( $48 \%$ versus $19 \%$ ), waarbij $90 \%$ van de patiënten uit die centra betrokken was. De disciplines die psychosociale zorg gaven, waren in volgorde van frequentie: maatschappelijk werker, klinisch psycholoog, arts en verpleegkundige. Hieruit blikt dat psychosociale zorg breed gedefinieerd is.

$77 \%$ van de erkende en $53 \%$ van de nietwerkende afdelingen stuurden patienten na de revalidatiefase zonodig door naar instanties woor psychosociale zorg, zoals het AIAGG of algemeen maatschappelijk werk.

Ook nu hadden de meeste revalidanten een hartintarct of hartoperatie gehad. $65 \%$ van de instellingen hanteerde geen expliciete leeftijsgrens, $1 \%$ revalideerde geen patienten boven de 55 jaar, $7 \%$ had 60 jaar als leeftijdsgrens, $15 \% 65$ jaar en $3 \% 70$ jaar.

De helft van de ziekenhuizen revalideerde alleen patiënten uit eigen huis. Dat gold ook voor $37 \%$ van de erkende afdelingen, die officieel een regionale functie hebben, terwijl opvallenderwijs $20 \%$ van de niet-erkende afdelingen ook patiënten van elders revalideerde

Het totaal aantal gerevalideerde patienten in Nederland werd in 1984 retrospectief geschat op 11.000 (5.200 in erkende en 5.800 in niet erkende afdelingen). De onder zoekers gingen uit van ongeveer 40.000 patentiële kandidaten (24.017 patiênten met een hartinfarct, die het ziekenhuis levend verlieten; 8689 patiênten na hartoperatie; 7808 patiënten met dreigend infarct of andere ischemische hartziekte) voor hartrevalidatie. 


\section{Tabell}

Hartrevalidatie in Nederland: aard en omvang

\begin{tabular}{|c|c|c|c|}
\hline Onderzoek & 1 & $\| 1$ & 111 \\
\hline Onderzoekers & Weeda \& Visser & Dixhoom wan ea & Maes ea \\
\hline Jaar wan onderzoek & 1979 & 1984 & 1986 \\
\hline Onderzoeksinstrument & schrifteligke enquête & schriftelijke enquête & schriftelijke enquête \\
\hline Respondenten & $\begin{array}{l}\text { cardiologen } \\
\text { verpleegkundigen } \\
\text { fysiotherapeuten }\end{array}$ & $\begin{array}{l}\text { cardiologen } \\
\text { verpleegkundigen } \\
\text { iysiotherpeuten }\end{array}$ & onbekend \\
\hline Pespons & $70 \%$ & $95 \%$ & $84 \%$ \\
\hline Pevalidatietase & 1 en 2 & 2 & 2 \\
\hline $\begin{array}{l}\text { Aantal aangeschreven } \\
\text { instellingen }\end{array}$ & 140 & 89 & 197 \\
\hline $\begin{array}{l}\text { Onderzochte programma } \\
\text { onderdelen }\end{array}$ & alle & alle & alle \\
\hline Patiëntgegevens & nee & beperkt & nee \\
\hline
\end{tabular}

hetgeen impliceert dat slechts ongeveer een kwart van de patiënten gerevalideerd zou worden.

\section{Onderzoek III}

In 1986 is door Maes ea (1986) inopdracht van het Ministerie van WVC een inventarisatie gemaakt van de programmaonderdelen van revalidatieprogramma's na ontslag uit het ziekenhuis. Alle 197 ziekenhuizen en revalidatiecentra werden benaderd via een postenquête (zie tabel 1). De respons was $84 \%$, de achtergrond van de invullers was onbekend. Van de 139 instellingen die uiteindelijk informatie verstrekten, waren er 18 $(=13 \%)$ die geen revalidatie na ontslag gaven, maar de patienten naar elders verwezen. Alle overblijvende 121 afdelingen hadden als basis een fysiotherapieprogramma, 77 (64\%) boden daarnaast de mogelijkheid voor individuele gesprekken met een maatschappelijk werker, $54(=45 \%)$ hadden een klinisch psycholoog beschikbaar voor individuele consulten en in 30 afdelingen (25\%) werd aandacht besteed aan voorlichting en begeleiding in groepsverband.

\section{Commentaat}

Onduidelijk is of de inventarisaties van met name onderzoek I en ll een compleet beeld bieden. Hoewel in onderzoek II een respons gehaald wardt van $95 \%$ van de 89 
benaderde centra, ligt het totale aantal afdelingen dat revalidatie na ontslag geeft, waarschijnlijk hoger. Maes ea (1986) schatte dit aantal op 121, wat wil zeggen dat ongeveer een kwart van de instellingen niet in het onderzoek van Van Dixhoorn opgenomen is, waardoor het landelijk beeld er mogelijk anders uit zal zien. Er zijn geen aanwijzingen dat het aantal centra in de iwee tussenliggende jaren veranderd is.

De in de onderzoekingen I en II gehanteerde definitie van psychosociale zorg is zeer breed: deze omvat zorg door een maatschappelijk werker, een klinisch psycholoog, een wijkverpleegkundige, een revalidatiearts en een psychiater. Uiteraard is emotionele steun onderdeel van de inbreng van alle disciplines en kan daarom psychosociale zorg in brede zin genoemd worden. In dit proefschrift zal de term psychosociale zorg echter gereserveerd worden voor de professionele zorg in engere zin gegeven door een maatschappelijk werker of een klinisch psycholoog.

Een laatste punt van kritiek op de gepresenteerde resultaten is dat klinische revalidatie na ontslag uit het ziekenhuis niet onderscheiden wordt van poliklinische revalidatie.

\subsubsection{Onderzoek naar specifieke aspecten van zorg voor hartpatiënten}

\section{Onderzoek IV}

De onderzoekers van onderzoek III hebben ook gekeken naar inhoud, organisatievorm en problemen rondom groepsvoorlichting (Maes ea, 1986) (zie tabel lil). Bij de meeste van de 22 instellingen (de keuze hiervan werd niet in de verslaggeving aangeduid) die nader onderzocht werden, zijn de gegevens verzameld via een mondelinge enquête, van enkele afdelingen was schriftelijk materiaal beschikbaar. De respondenten waren afkomstig uit alle bij de zorg voor hartpatiënten betrokken disciplines.

Verder werd informatie vergaard over het "Project Hartgroepen" van de Provinciale Kruisvereniging Zuid-Holland, het project "Reîntegratie met Duo's" in Zuid-Limburg en over de meerdaagse bijeenkomsten voor hartpatiënten in "De Hartenark" te Bithoven.

Er bestond een grote verscheidenheid aan opvattingen over de vorm waarin de groepsbegeleiding diende plaats te vinden: een deel van de afdelingen koos voor een duidelijk gestructureerde, educatieve, informatieve opzet waarbij volgens een vast programma werd gewerkt; andere instellingen kozen juist voor een ongestructureerde benadering, waarbij gespreksonderwerpen door patiënten werden aangledragen en de groepsgesprekken zoveel mogelijk non-directief waren.

In vrijwel alle ziekenhuizen werd in de klinische fase gebruik gemaakt van audicvisuele middelen, in de poliklinische fase wisselde dit nogal. Hel geven van informatieve lezingen gevolgd door een groepsdiscussie, werd door sommige hulpverleners als bijzonder nuttig gezien, anderen vonden deze opzet te zwaar en voorzagen bovendien problemen in verband met de theterogeniteit van de patientenpopulatie. Het aantal disciplines dat bij een voorlichtingsprogramma aan bod kwam, variëerde in hoge mate: alle voorkomende disciplines konden erbij betrokken zijn.

Over het starttijdstip van het groepsprogramma werd eveneens nogal verschillend gedacht: een deel van de hulpverleners wilde zo snel mogelijk na ontslag starten, om te 
voorkomen dat de patiënt in het gevreesde "zwarte gat" zou vallen; anderen meenden dat later gestart diende te worden, omdat de patiënten in het begin nog niet toe zouden zijn aan zo'n groepsgebeuren. Ook over het al dan niet gezamenlijk in één groep plaatsen van infarct-en bypasspatiênten bestond geen eensgezindheid. In de praktijk werden uiteenlopende selectiecriteria gebruikt, zoals de ernst van het medisch ziektebeeld en de leettijd. In slechts enkele ziekenhuizen werden na het beëindigen van de groep follow-up sessies gegeven.

\section{Onderzoek $V$}

In opdracht van de Nederlandse Vereniging voor Fysiotherapie bij Hart- en Vaatziekten (NVFH) is begin 1988 door Gutker de Geus een inventarisatie gemaakt van fysiotherapie voor hartpatiennten tijdens opname in het ziekenhuis (NVFH, 1988; Gutker de Geus, 1988). Hiertoe werden, middels een post-enquête, 189 fysiotherapie-afdelingen (zie tabel II) benaderd, die verdeeld waren over 174 ziekenhuizen en 15 revalidatiecentra. De respons was $85 \%$, de respondenten waren allen fysiotherapeut. 136 ziekenhuizen namen hartpatiënten op. In $98 \%(\mathrm{~N}=136)$ van de ziekenhuizen werd tijdens de opname fysiotherapie gegeven in de vorm van: wandelen, actieve oefeningen, ergometrie, sport en spel, en ontspanningsoefeningen (respectievelijk in 100\%,93\%,73\% en $26 \%$ van de ziekentiuizen).

De behandeling per sessie duurde doorgaans 10 tot 30 minuten. In driekwart van de ziekenhuizen werd de patiënt tijdens opname eenmaal per dag behandeld en in de rest tweemaal. In 55\% van de ziekenhuizen werd de patiënt gedurende de gehele opname individueel behandeld, in $45 \%$ individueel in de beginfase en groepsgewijs na voldoende mobilisatie.

Fysiotherapie na een hartinfarct startte doorgaans de tweede of derde dag. Voor bypassen klepoperatiepatiënten lag dit tijdstip enkele dagen later. In de meeste cardiochirurgische centra werd met fysiotherapie al voorafgaand aan de ingreep gestart. De duur van de fysiotherapie bedroeg na een infarct 5 tot 15 dagen, na een bypass 5 tot 10 dagen en na een klepoperatie 5 tot 15 dagen. Dit hing uiteraard samen met de opnameduur. $90 \%$ van de fysiotherapeuten hield een eigen patiëntendossier bij.

Doorgaans vond er wekelijks overleg plaats met arts en verplegend personeel. Besprekingen met maatschappelijk werker, klinisch psycholoog of revalidatiearts kwamen minder frequent voor. Bij 20\% van de ziekenhuizen kwamen de patiênten na ontslag niet meer terug voor fysiotherapie; onduidelijk was of zij doorverwezen werden naar een gespecialiseerd centrum; bij de andere ziekenhuizen waren de patiënten doorgaans binnen één week terug.

\section{Onderzoek VI}

In 1991 is door Schäperclaus ea (1991) een enquête-onderzoek gedaan naar sportgroepen voor hartpatiênten in de nazorgfase in Nederland (zie tabel II). Doel van de enquête was de organisatie, omvang. doelstellingen en programma's in kaart te brengen. 157 bekende verenigingen werden aangeschreven en de respons was $94 \%$. De achtergrond van de respondenten is niet beschreven in het onderzoek. 
De eerste patientenvereniging werd in 1966 opgericht, terwijt $6 \%$ wan de huidige verenigingen reeds voor 1975 actief was. $74 \%$ werd na 1980 opgericht, waarvan de helft tussen 1980 en 1985. 69\% van de verenigingen is aangesloten bij Hart in Beweging (HIB), $9 \%$ bij de Nederlandse Invalidenbond, $15 \%$ is elders aangesloten (provinciale sportraden, belangenvereniging voor patiënten van de Nederlandse Hartstichting of invalidenbonden). $69 \%$ van de verenigingen hebben trimgroepen (gemiddeld 21 deelne mers per groep), $16 \%$ zwemgraepen (gemiddeld 34 deelnemers per groep) en $15 \%$ hebben beide. Bijeenkomsten wan zowel trim- als zwemgroepen vinden in $95 \%$ van de gevallen eenmaal per week plaats en duren doorgaans één uur. Er zijn gemiddeld drie sportgroepen per vereniging.

Het totaal aantal deelnemers van de onderzoeksgroep lag op 10.624. Een schatting van de totale populatie in Nederland komt uit op 12.000. De deelnemers zijn gemiddeld drie jaar lid. Dit betekent dat zich circa 4.000 nieuwe deelnemers per jaar aanmelden. Van de 30.000 tijdens opname gerevalideerde patiënten stroomt $13 \%$ door naar dit soort patientengroepen.

\section{Tabel II}

Hartrevalidatie in Nederland: specifieke onderdelen

\begin{tabular}{|c|c|c|c|c|}
\hline Onderzoek & IV & V & VI & $V \| l$ \\
\hline Onderzoekers & Maes ea & Gutker de Geus & Schäperclaus ea & Schäperclaus ea \\
\hline $\begin{array}{l}\text { Jaar van } \\
\text { onderzoek }\end{array}$ & 1986 & 1988 & 1991 & 1991 \\
\hline $\begin{array}{l}\text { Onderzoeks- } \\
\text { instrument }\end{array}$ & $\begin{array}{l}\text { mondellinge } \\
\text { enquëte }\end{array}$ & $\begin{array}{l}\text { schriftelijke } \\
\text { enquête }\end{array}$ & $\begin{array}{l}\text { schriftelijke } \\
\text { enquête }\end{array}$ & $\begin{array}{l}\text { schriftelijke } \\
\text { enquête }\end{array}$ \\
\hline Respondenten & diverse disciplines & fysiotherapeuten & anbekend & patiënten \\
\hline Respons & $100 \%$ & $85 \%$ & $94 \%$ & onbekend \\
\hline Revallidatiefase & 2 & 1 & 3 & 3 \\
\hline $\begin{array}{l}\text { Aantal } \\
\text { aangeschreven } \\
\text { instellingen }\end{array}$ & 22 & 189 & 157 & 10 \\
\hline $\begin{array}{l}\text { Onderzochte } \\
\text { programina- } \\
\text { onderdelen }\end{array}$ & groepsvoorlichting & fysiotherapie & fysiotherapia & fystotherapie \\
\hline Patiëntgegevens & nee & nee & ja & ja \\
\hline
\end{tabular}




\section{Onderzoek VII}

In hetzelfde onderzoek van Schăperclaus ea (1991) zijn ook de kenmerken van deelnemers aan sportgroepen voor hartpatiênten onderzocht (zie tabe: II). Deelnemers van 10 verenigingen (de reden van keuze is niet beschreven) werden na afloop wan het sportuurtje uitgenodigd om vragenlijsten in te vullen. De vragen betroffen enige persoonskenmerken, de gezondheidstoestand, de gezondheidsbeleving en risicolactoren. Hier zullen aleen de aspecten aan bod komen die relevant zijn voor dit literatuuronderzoek.

136 deelnemers, waarvan $18 \%$ vrouwen, verleenden hun medewerking. Onduidelijk blifft hoeveel en welke ex-patiënten niet hebben deelgenomen, waardoor de representativiteit van de data in het vage blift. $86 \%$ van de deeinemers was tussen de 50 en 70 jaar oud, $5 \%$ ouder dan 70 jaar. $72 \%$ had een hartinfarct achter de rug. $36 \%$ een bypassoperatie, $6 \%$ een kiepoperatie en $18 \%$ had een andere hartziekte. $68 \%$ was tijdens de opname al gerevalideerd.

\section{Commentaar}

De mondelinge enquête blijkt een goed instrument te zijn om de gevarieerdheid van de psychosociale groepsbegeleiding in de praktijk in kaart te brengen, terwijl de respons hoog is. Er is een adequaat beeld ontstaan van dit deel van de zorg voor hartpatienten. Het uitvoeren van een mondelinge rondgang is echter tijdsintensief en kan dus maar op beperkte schaal plaatswinden.

Een kanttekening bij het onderzoek van Maes ea (1986) is dat de groepen die deel uitmaken van een revalidatieprogramma na ontslag uit het ziekenhuis, en de groepen die georganiseerd worden in het kader van de nazorg, tezamen geanalyseerd zijn en dus impliciet aan elkaar gelijkgesteld zijn. Het is zaak juist hierin een tweedeling aan te brengen, omdat ze zich onderscheiden in doelstellingen en uitgangspunten.

Een kanttekening bij het onderzoek naar fysiotherapie voor hartpatienten is dat de verstrekte gegevens en getallen mogelijk overtrokken zijn, omdat ze verstrekt zijn door fysiotherapeuten zelf. De enquête per patiënt blifkt een goed middel om verhoudingsgetallem te bepalen die, voorzaver het de steekproef betreft, zeer precies zijn. Onduidelijk blifft in hoeverre de steekproef representatief is voor de deelnemers aan sportgroepen voor hartpatiënten.

\subsubsection{Beschouwing over de hartrevalidatie in Nederland}

Nagenoeg alle ziekenhuizen blijken tijdens de opname fysiotherapie te geven. Of er verder nog andere programma-onderdelen worden aangeboden, is onbekend. Met name voorlichting zou onderdeel kunnen zijn, maar valt waarschijnlijk in de meeste ziekenhuizen niet onder revalidatie.

Het aantal afdelingen dat hartpatiënten revalideert ma ontslag uit het ziekenhuis laat door de jaren heen een duidelijke toename zien: van 46 in 1979 tot ongeveer 120 eind jaren tachtig. Er zijn op basis van het financieringsmodel drie soorten afdelingen te onderkennen: afdelingen voor klinische revalidatie, afdelingen met revalidatiedagbehandeling en 
afdelingen die fysieke reconditionering geven. Van deze latste groep blikkt, volgens Van Dixhoorn (1988), de helft tot tweederde naast fysiotherapie ook psychosociale zorg te geven, gecombineerd met regelmatig teamoverleg, wat betekent dat een groot deel van deze groep de vergelijking met een erkende afdeling op dit punt goed kan doorstaen.

Fysieke training, in welke vorm dan ook, en medisch specialistische zorg wormen samen, vanaf de start van hartrevalidatie, het hoofdbestanddeel van het gehele zorgtraject dat een hartpatiènt kan afleggen. De rol die deze onderdelen spelen tijdens de mobilisatie, de revalidatie en in de patiëntengroepen is redelijk goed in kaart gebracht. In de praktijk van de revalidatie na ontslag bleek overigens wel een grote variatie te bestaan in opbouw, duur en frequentie van de fysiotherapie. De start van het fysieke programma na ontslag vindt door de jaren heen steeds eerder plaats, de duur wordt steeds korter. De zorg staat vaker onder leiding van een multidisciplinair team en omvat meer psychosociale begeleiding. De leeftijdsgrens voor de patiënten wordt geleidelijk losgelaten (Dixhoorn van ea, 1988).

Er is geen eenduidigheid te bespeuren in de opvattingen over de vraag hoe psychosociale zorg (zowel individueel als in groepswerband) gegeven dient te worden; over een systematische aanpak van secundaire preventie is nauwelijks iets bekend. Wel is de trend waarneembaar dat er steeds meer klinisch psychologen en diëtisten betrokken worden bij de revalidatie van hartpatiënten en steeds minder verpleegkundigen, hetgeen wil zeggen dat de revalidatie organisatorisch losser is komen te staan van de mobilisatie tijidens de opname.

Er is een ernstig gebrek aan exacte aantallen en kenmerken van patiënten die revalidatie krijgen tijdens opname of na ontslag uit hell ziekenhuis.

Concluderend kan gesteld worden dat in de praktijk de revalidatie van hartpatiënten primair gericht is op conditieverbetering, in een deel van de ziekenhuizen aangevuld met een of andere vorm wan psychosociale begeleiding. Een systematische aanpak gericht op secundaire preventie ontbreekt nagenoeg geheel.

\subsection{EUROPA}

\subsubsection{West-Duitsland}

In West. Duitsland worden de meeste patiënten na hun opmame, die overigens gemiddeld daar nog drie à vier weken duurt, doorverwezen naar speciale klinieken woor klinische revalidatie. Deze worm van revalidatie na ontslag duurt doorgaans vier weken. Er zijn ongeveer tachtig klinieken en "Kurorten" voor hartpatiënten, met verschillende niveaus van zorg. Er zijn vilif gespecialiseerde hartrevalidatieklinieken (Jetté ea. 1988). Deze centra werden in de zeventiger jaren opgezet, omdat hartpatiënten steeds vroeger gemobiliseerd werden. Daarnaast werd een start gemaakt met ambulante hartpatiënten. groepen (Gleichmann ea, 1983). Deze waren zowel bedoeld als altematief voor, maar 
ook als aanvulling op de klinische revalidatie (Stocksmeier, 1978). Er zijn drie publicaties bekend over de nazorgtase (sport/oetengroepen) van hartpatienten. De rest van het zorgtraject is niet in kaart gebracht.

\section{Onderzoek VIII}

In 1982 is een post-enquête gestuurd naar alle 420 geregistreerde ambulante trainingsgroepen voor hartpatiênten (Gleichmann ea, 1983) (zie tabel III). De respons bedroeg $67 \%$. De formulieren werden meestal gezamenlijk door artsen en fysiotherapeuten ingevuld.

Het land telde in 1982 ongeveer 280 "Träger" voor hartpatiëntengroepen (sportverenigingen, sportverenigingen voor gehandicapten, particuliere clubs, walkshogescholen). In totaal werden er zo'n 500 sportgroepen getraceerd, waarvan 390 trainings- en 110 oefengroepen. De eerste trainingsgroepen zijn begin zeventiger jaren gestart; vanat 1978 was een duidelijke toename te bespeuren: $45 \%$ van de groepen ontstond na dit jaar.

De meeste groepen bleven langer dan 2 jaar bij elkaar; $65 \%$ waren gesloten groepen, met steeds dezelfde deelnemers dus. $60 \%$ van de groepsleden werd deelnemer middels verwijzing door artsen en revalidatieklinieken, en $30 \%$ door eigen initiatief. Slechts een gering percentage deelnemers werd aangetrokken via reclame-activiteiten van de groepen zelf. De voornaamste reden om te stoppen met de groep (aantallen zijn niet bekend) was een gebrek aan motivatie (40\%); medische redenen kwamen op de tweede en priveredenen op de derde plaats.

Voor méér dan 90\% van de groepen moest een inspannings-ECG gedaan zijn alvorens patiënten werden toegelaten (75 Watt was vereist voor een trainingsgroep en 50 Watt voor een oefengroep). In 60\% werden standaard ook andere non-invasieve technieken toegepast (bijvoorbeeld een röntgen-thoraxfoto en laboratoriumonderzoekingen). In $50 \%$ werd een meting van de druk in de rechter harthelft gedaan. Bij $34 \%$ van de patienten werd ook een coronairangiografie verricht.

Het merendeel van de groepen hield eenmaal per week, gedurende gemiddeld anderhalf uur, een bijeenkomst. De inhoud van de programma's bestond uit gymnastische oefemingen, loopoefeningen en speltherapie zonder prestatiemotief; $65 \%$ hield regelmatig groepsgesprekken en $40 \%$ deed aan ontspanningstraining. In Duilsliand wordt deze vorm van nazorg door de ziektekostenverzekeraars vergoed; de "Krankenkasse" is dus de belangrijkste financier, maar ook bijdragen van verenigingen en van de deeinemers zelf vormen een bron van inkomsten.

Het toenmalige aantal deelnemers was 9.000. Tat dan waren 16.000 patiënten lid geweest of nog steeds lid. De leeftijd van de deelnemers varieerde van 23 tot 80 jaar en de geslachtsverhouding was 5 (mannen) : 1 (vrouwen). $68 \%$ van de deellnemers had een hartinfarct achter de rug, $10 \%$ had of een coronaire bypass- of een klepoperatie ondergaan, $11 \%$ leed aan een klinisch manifeste coronaire hartzlekte zonder infarct (meestal angina pectoris), $4 \%$ had alleen maar cardiale risicofactoren zonder een klinisch manifeste coromaire hartziekte, $1 \%$ had een andere hartziekte en $6 \%$ betrof gezonde 
partners van patiënten. $3 \%$ kreeg binnen twee jaar, gemeten vanaf de start met de patientengroep, een re infarct en bijna $1 \%$ was het slachtoffer van een plotselinge dood. $20 \%$ van de overlevenden na een hartinfarct zou in aanmerking komen voor deze groepen, in 1982 deed in concreto $10 \%$ mee (Gleichmann ea, 1983). De filosofie achter deelname is een levenslange betrokkenheid.

\section{Onderzoek IX}

In 1991 is door Schäperclaus ea (1991), middels een schriftelijke enquête, een onder. zoek gedaan naar sportgroepen voor hartpatiënten in West-Duitsland (zie tabel III). Er werd een steekproef genomen van 280 verenigingen uit een totaal van 2.500 . De respons was $63 \%$ (177), de achtergrond van de respondenten was onbekend. Doel was het inventariseren van organisatie, omvang, doelstellingen en programma's.

$\mathrm{Na} 1978$ is het aantal sportverenigingen sterk toegenomen. De helft is opgericht na 1980. In 1985 zijn er ongeveer 1.100 groepen met rond de 25.000 deelnemers, in 1990 meer dan 2.500 groepen met meer dan 55.000 deelnemers. $57 \%$ van de groepen is gearganiseerd binnen sportverenigingen, $20 \%$ binnen gehandicaptensportverenigingen en de rest binnen particuliere verenigingen, volkshogescholen of combinaties hiervan. Da 177 verenigingen telden 340 groepen, waarvan 261 trainingsgroepen en 79 oefengroepen. Het totale aantal deelnemers bedroeg 6.000, gemiddeld 18 per groep. De groepen kwamen gemiddeld eenmaal per week bij elkaar, gedurende ongeveer anderhalf uur.

\section{Tabell III}

Hartrevalidatie in (voormalig) West-Duitsland

\begin{tabular}{|c|c|c|c|}
\hline Onderzoek & VIII & IX & $x$ \\
\hline Onderzoekers & Gleichmann ea & Schäperclaus øa & Schäperctaus ea \\
\hline Jaar van onderzoek & 1982 & 1991 & 1991 \\
\hline Onderzoeksinstrument & schriltelijke enquête & schriftelinke enquêle & schrillelijke enquâte \\
\hline Respondenten & $\begin{array}{l}\text { artsen } \\
\text { fysiotherapeuten }\end{array}$ & onbekend & patienten \\
\hline Respons & $67 \%$ & $63 \%$ & onbakend \\
\hline Revalidatiefase & 3 & 3 & 3 \\
\hline $\begin{array}{l}\text { Aantal aangeschreven } \\
\text { instelingen }\end{array}$ & 420 & 280 & 5 \\
\hline $\begin{array}{l}\text { Onderzochte programma } \\
\text { onderdelen }\end{array}$ & alle & fysiotherapie & fysiotherapie \\
\hline Patientgegevens & ja & ja & ja \\
\hline
\end{tabular}




\section{Onderzoek $x$}

In het genoemde onderzoek van Schäperclaus ea (1991) is door 70 deelnemers van sportverenigingen een uitgebreide enquête ingevuld, met als doel een reeks patiëntgegevens te verzamelen (zie tabel III).

$76 \%$ van de deelnemers was man. De leeftijdsverdeling was: $15 \%$ jonger dan 50 jaar, $75 \%$ tussen 50 en 70 jaar en tenslotte $10 \%$ auder dan 70 jaar. $62 \%$ had een hartinfarct achter de rug, $36 \%$ een bypassoperatie, 3\% een klepoperatie, $29 \%$ een andere hartziekte. $84 \%$ had al deelgenomen aan een klinisch hartrevalidatieprogramma; blijkbaar stroomde $16 \%$ rechtstreeks door vanuit het opnameziekenhuis, of was helemaal niet opgenomen geweest.

\section{Commentaar}

In het eerste project is sprake van een respons van $67 \%$. De auteur concludeert in zijn artikel dat hierdoor een representatiel beeld is verkregen van de sportgroepen voor hartpatiënten. Het is echter onduideiijk op welke manier de niet-responderende groepen functioneerden. Het is mogelijk dat zij niet of nauwelijks van de grond zijn gekomen en daarom niet reageerden. De projecten VIII en IX zijn gebaseerd op steekproeven. Ook hier bliff de vraag open inhoeverre de gegevens representatief zijn voor de gehele populatie.

Gesteld dient te worden dat de drie beschreven onderzoeken een goed beeld verschaffen van de sportgroepen voor hartpatiënten in West-Duitsland. Ook zijn er goede patiëntgegevens bekend. Het aantal deelnemers blijkt vanaf 1982 enorm toegenomen: destijds waren er 9.000 , in 198525.000 en in 199055.000 . Deelname aan zo'n sportgroep is door de jaren heen een belangrijk onderdeel geworden van de nazorg voor hartpatiënten.

\subsubsection{Engeland}

\section{Onderzoek XI}

In 1985/86 is een schriftelijke enquête gehouden om de hartrevalidatie na ontslag uit het ziekenhuis in Groot-Brittannië te kunnen inventariseren (Green ea, 1988; Davidson ea, 1988). 132 "Health Districts" werden aangeschreven (zie tabel IV). Uit de respons van $70 \%$ kwam naar voren dat in 41 districten hartrevalidatie werd gegeven, in de overige 57 districten niet. Daarnaast werd nog van vijf andere instanties informatie verkregen. De enquêtes werden ingevuld door fysiotherapeuten.

Alle instellingen ( $N=46$ ) accepteerden post-infarctpatiënten, $63 \%$ ook patiënten met angina pectoris, en $65 \%$ patiënten die een coronaire bypassoperatie hadden ondergaan. Meer dan de helft hanteerde een leettijdsgrens, variërend van 55 tot 70 jaar. $17 \%$ gaf individuele behandeling, de rest behandelde groepgewijs. $17 \%$ gebruikte standaard een fietstest voor de start van het programma, $19 \%$ gebruikte de fietstest slechts op indicatie. $85 \%$ van de programma"s startte binnen acht weken na het infarct; meer dan de helft startte binnen vier weken. De duur bedroeg gemiddeld 6 tot 8 weken. De meeste 
programma's kenden twee sessies per week. Eén centrum gaf klinische revalidatie en dit programma duurde drie weken.

Alle instellingen hadden fysiotherapeuten ingeschakeld, $24 \%$ arisen en $15 \%$ verpleegkundigen. De helft had diëtisten bij de programma's betrokken. $26 \%$ klinisch psychologen en $24 \%$ maatschappelijk werkers. $61 \%$ van de instellingen werd tijdens de oeteningen zo nu en dan gecontronteerd met angina pectoris en $11 \%$ wei eens met een re-infarct. Slechts $25 \%$ had sporadisch te maken met een circulatiestilstand, die soms gevolgd werd door de dood. Slechts éen instelling had een follow-up georganiseerd.

\section{Commentaar}

Reeds in 1970 werd een korte enquête gestuurd naar de leden van de "British Cardiac Society" (Groden ea, 1971) om de hartrevalidatiefaciliteiten in Engeland te inventariseren. Slechts enkele ziekenhuizen bleken faciliteiten te hebben voor revalidatie na ontslag uit het ziekenhuis.

Omdat er toentertijd nog weinig belangstelling was voor hartrevallidatie, werd in 1975 een gezamenlijke werkgroep van de "Royal College of Physicians of London" en de "British Cardiac Society" opgericht, met als doel know-how betreffende hartrevalidatie te verzamelen en aanbevelingen te formuleren ontrent het wormgeven aan de hartrevalidatie in Engeland (Royal College of Physicians/British Cardiac Society, 1975). In 1986 volgde de in dit hoofdstuk beschreven enquete. De Coronary Prevention Group (1989) heeft in 1988 aanbevelingen geformuleerd hoe hartrevalidatie vorm te geven.

De hiervoor besproken enquête uit 1986 toont duidelijk aan dat ook in Engeland revalidatie nagenoeg synoniem is aan fysieke training, en dat zowel psychosociale zorg als secundaire preventie zeer beperkt aan bod komen. Verder dient gesteld te worden dat hartrevalidatie na ontslag anno 1986 in Engeland weinig verspreid was en slechts in minder dan de helft van het land werd toegepast.

\subsubsection{Italliè}

\section{Onderzoek XII}

In 1987 is in ttalï̈ een schriftelijke enquête gestuurd naar 222 bekende instellingen om inzicht te krijgen in de hartrevalidatie na ontslag uit het ziekenhuis (Giordano. 1989). Uit de respons van $72 \%$ bleek dat 59 instellingen na ontslag hartrevalidatie gaven (zie tabel IV). Maar lietst $70 \%$ bleek in het noorden van ltalië te liggen. De achtergrond van de invullers was onbekend.

In totaal werden ongeveer 11.000 patiënten per jaar gerevalideerd. $65 \%$ was hattintarctpatiënt. Alle instellingen gaven revalidatie direct na de ziekenhuisopname: 34 in poliklinische vorm, 9 in klinische vorm en 16 in beide vormen. De gebruikte diagnostische procedures waren: fietstest ( $100 \%$ van de instellingen), echo $(96 \%)$ en Holter monitoring $(80 \%)$

Medische en fysieke aspecten stonden steeds centraal in de programma's, terwijl veel minder gedaan werd aan psychologische begeleiding $(42 \%)$ en diëetadviezen (31\%). 


\section{Tabel IV}

Hartrevalidatie in Engeland en Italiè

\begin{tabular}{|c|c|c|}
\hline Onderzoek & $x \mid$ & $x \|$ \\
\hline Land & Engeland & Italiè \\
\hline Onderzoekers & Green ea & Giordano \\
\hline Jaar wan onderzoek & 1986 & 1987 \\
\hline Onderzoeksinstrument & schriftelike enquête & schriftelike enquête \\
\hline Respondenten & fysiotherapeuten & onbekend \\
\hline Pespons & $70 \%$ & $72 \%$ \\
\hline Revalidatiefase & 2 & 2 \\
\hline $\begin{array}{l}\text { Aantal aangeschreven } \\
\text { instellingen }\end{array}$ & 132 & 222 \\
\hline $\begin{array}{l}\text { Onderzochte programma } \\
\text { onderdelen }\end{array}$ & alle: & alle \\
\hline Palténtgegevens & nee & beperkt \\
\hline
\end{tabular}

Voorlichting over risicofactoren (75\%) kwam wel frequent voor. Alle fysieke programma's werden gesuperviseerd door cardiologen, fysiotherapeuten of verpleegkundigen. Bijna alle instellingen werden gesteund door de Servizio Sanitario Nazionale.

\section{Commentaar}

Dankzij deze enquête zijn er redelijk gedetailleerde gegevens beschikbaar. Slechts een klein deel van de ziekenhuizen heeft de mogelijkheid hartpatiënten te revalideren. Italië kent een gedifferentieerd aanbod van faciliteiten in een zeer beperkt aantal centra: klinische en poliklinische revalidatie en een combinatie van beide! Het is niet duidelijk op wat voor gronden patiënten klinische en/of poliklinische revalidatie krijgen. Gezien de vrij eenzijdige verdeling over het land, maeten andere dan revalidatiedoelstellingen een belangrijke rol spelen.

\subsubsection{Commentaar op studies uit Europa}

In Europa zijn nog maar weinig enquetes gehouden naar de stand van zaken op het gebied van de zorg voor hartpatiënten (in drie fasen): van de voormalige Sovjet-Unie en de voormalige Oostblok-landen is geen inventarisatie bekend, hetzelfde geldt voor Scandinavië, lerland en Schotland, Frankrijk, Spanje en Portugal, Oostenrijk en Zwitser- 
land. Van de drie landen die wel onderzoek gedaan hebben, heeft West-Duitsland een zeer uitgebreid netwerk van patiënten sportgroepen. In Engeland en Italie is revalidatie na ontslag uit het ziekenhuis in het grootste deel van het land niet beschikbaar. Overigens ligt in alle landen de nadruk op fysieke revalidatie cq conditieverbetering.

\subsection{NIET-EUROPESE LANDEN}

\subsubsection{Verenigde Staten}

\section{Onderzoek XIII}

In 1983 werd een schriftelijke enquête gehouden op initiatief van de Revalidatie Commissie van de Hartstichting van Virginia in de Verenigde Staten (Wolfe ea. 1987) (zie tabel $V$ ). De respons was $90 \%$ (44 van de 49 instellingen). De respondenten waren artsen, verpleegkundigen en fysiotherapeuten.

De opzet van de revalidatie variëerde in hoge mate: ongeveer eenderde van de instellingen bood alleen revalidatie tijdens de opname, een deel alleen poliklinische revalidatie of een of andere vorm van nazorg, bijna de helft een combinatie van twee of drie van de genoemde mogelijkheden.

Fysieke training werd gegeven door alle instellingen, dieetadvisering door $93 \%$; stoppen met roken $\mathrm{kwam}$ aan de orde in $65 \%$ van de instellingen en stressmanagement in $63 \%$. Er werden 4.300 patiënten per jaar gerevalideerd, driekwart was post-infarctpatiënt. De rest betrof post-operatieve patiënten, "coronary prone"-patiënten, soms patiënten met angina pectoris of met andere cardiovasculaire ziekten. Slechts 15 tot $20 \%$ van de patiënten uit Virginia die een infarct overleefden, kreeg revalidatie na ontslag. De meeste instellingen konden zichzelf financieel onvoldoende bedruipen.

\section{Onderzoek XIV}

Ten behoeve van de enquêtering van het hierna te beschrijven onderzoek werd een aselecte steekproef getrakken (Southard \& Broyden, 1990) van 202 uit 1195 bekende instellingen, met als doel psychosociale aspecten binnen de hartrevalidatie te inventariseren. $58 \%$ (107) leverde bruikbare informatie (zie tabel V). De achtergrond van de respondenten was onbekend.

De verdeling naar soort revaliderende instelling $(\mathrm{N}=107)$ was: $75 \%$ ziekenhuizen, $12 \%$ privé-klinieken, $9 \%$ "community clinics" en $4 \%$ universiteitsziekenhuizen. $71 \%$ van de instellingen gat zowel revalidatie tijdens opname as na ontslag, $25 \%$ alleen na ontslag en $4 \%$ alleen tijdens opname.

In de helft van de instellingen werden niet-gestandaardiseerde psychosociale methoden gebruikt; eenderde gebruikte gestandaardiseerde methoden. De resultaten van de psychosociale screening werden in ongeveer tweederde van de instellingen informeel besproken met andere teamleden, bij de rest gebeurde dit middels een formeel teamoverleg of door het schrijven van een rapport; in minder dan eenderde van de instellingen 
werden de psychosociale gegevens geintegreerd in een muttidisciplinair geschreven rapport.

Erwerden diverse psychosociale interventies toegepast: "patient support groups" in $71 \%$ van de instellingen, betrekking wan het gezin in $62 \%$, stress management programma's in $60 \%$ en een korte psychosociale consultatie in $62 \%$. Minder toegepast werden: bioteedback ( $39 \%$ ), uitgebreide individuele psychotherapie ( $32 \%$ ) en groepspsychotherapie (18\%).

Met name verpleegkundigen verzorgden de psychosociale screening, terwill maatschappelijk werkers en klinisch psychologen vooral kortdurende consulfaties en individuele psychotheraple gaven. Meer dan de helft van de instellingen vond dat ontoereikende financiele vergoeding het gebruik van psychosociale diensten negatief beinwloedde.

\subsubsection{Canada}

\section{Onderzoek XV}

In 1985 is een enquẻte gehouden in Ontario door de Queen's Universiteit in samenwerking met het ministerie van Toerisme en Recreatie (Atdeling Sport en Fitness) (Wolfe ea. 1990). Van de 43 aangeschreven hartrevalidatieafdelingen gaven er 37 (86\%) respons (zie tabel V). Respondenten waren artsen, verpleegkundigen en fysiotherapeuten.

25 afdelingen waren werbonden aan een "hospital" of "medical clinic", 10 aan "YMYWCA's", 5 waren "community based organizations" en 3 waren geliëerd aan "kinesiology/physical education"-afdelingen van universiteiten. 5 afdelingen gaven alleen rewalidatie tijdens de opname, 16 alleen nazorg. De rest van de afdelingen gaf program,ma's die samengesteld waren uit elementen afkomstig uit wee of drie fasen van het zorgtraject dat een hartpatiënt kan doorlopen.

Alle afdelingen gaven fysieke training. In aanvulling hierop boden 25 afdelingen diëetadvisering aan, 20 stressmanagement en 19 hielden zich bezig mel programma's gericht op het stoppen met roken. De patiënten kregen de programma-onderdelen individueel aangeboden of in gestructureerde groepen waaraan, naast een fysiotherapeut, ook andere disciplines meewerkten.

Extrapolatie van de enquêtegegevens leert dat in 1985, gerekend over alle 43 aangeschreven afdelingen tezamen, ongeveer 5.000 patienten deeinamen aam de diverse hartrevalidatieprogramma's; de hellt van de patiënten had een infarct gehad en eenderde een hartoperatie. Naar schatting werd 10 tot $15 \%$ van alle patiënten na een infarct gerevalideerd, helgeen inhoudt dat er in Canada jaarlijks tussen de 25.000 en 37.500 infarctpatienten ziln. Vooral artsen, verpleegkundigen en fysiotherapeuten, en slechts enkele diëtisten en klinisch psychologen waren bij de revalidatie betrokken.

\section{Commentaar op studies afkomstig uit Noord-Amerika}

Opmerkelijk in Noord-Amerika (Verenigde Staten plus Canada) is dat er na ontslag geen klinische revalidatie is. Verder valt op dat een deel van de instellingen slechts revalideert tijdens de opname, een deel alleen na ontslag en een deel alleen in de nazorgfase 
(sportgroepen). In de diverse onderzoeken worden al deze verschillende benaderingen niet uitgesplitst bij het berekenen wan het aantal gerevalideerde patienten, de beschikbare programmaonderdelen en de disciplines. Het resultaat is dat het onmogelik is een juisi beeld te krijgen van de hartrevalidatie, onderscheiden in haar drie fasen. Hierdoor is het ook moeilijk om wergelikingen te maken met andere landen. De veronderstelling van een samenhang met het feit dat de revalidatie van hartpatiënten nog onvoldoende ontwikkeld is in Noord-Amerika, wordt onderstreept door de auteurs.

In het onderzoek van Southard \& Broyden (1989) wordt een uiterst rume definitie gebrukt voor psychosociale zorg. Wanneer we ons, zoals reeds eerder is gesteld, beperken tot de professionele psychosociale zorg gegeven door maatschappelijk werker en/of klinisch psycholoog, blikt dat niet $75 \%$ maar slechts $10 \%$ van de instellingen deze professionele hulp biedt. Daar komt bij dat de respons van dit onderzoek op $58 \%$ uitkwam. Het is aannemelijk dat er bij de non-respondenten zeer veel instellingen zitten die helemaal geen psychosociale zorg geven. In deze twee landen wordt weh relatief veel aandacht besteed aan secundaire preventie activiteiten.

\subsubsection{Australië}

\section{Onderzoek XVI}

In 1984/85 is op verzoek van de Revalidatie Commissie van de Hartstichting van Australië een enquête gehouden (Worcester, 1986) (zie tabel V). Alle 153 aangeschreven ziekenhuizen reageerden. De inwullers waren artsen en verpleegkundigen.

$69 \%$ (106) kende een oefenprogramma tijdens de opname, in alle gevallen op individuele basis. Dit programma werd in $69 \%$ van deze zlekenhuizen gegeven door verpleegkundigen en in de rest door fysiotherapeuten. In 59\% (90) werd tijdens de opname een inspanningstest verricht; het merendeel testte echter slechts een klein deel van de patienten op hun belastbaarheid.

Groepseducatieprogramma's werden in 18\% van de 153 ziekenhuizen tijdens de opname gegeven. In $71 \%$ was de diëtiste beschikbaar voor individuele consulten. Individuele psychosociale hulp door maatschappelik werker of klinisch psycholoog was moge ijk in $84 \%$, terwijl $58 \%$ ergotherapie toepaste bij de revalidatie.

Slechts 26 (17\%) van de 153 ziekenhuizen hadden na ontslag een gestructureerd groepsoefenprogramma, $8 \%$ stuurde soms patiënten door naar een ander ziekenthuis. In ongeveer een kwart onderging de helft van de patiënten poliklinisch alsnog een inspanmingstest. Eveneens ongeveer een kwart had een groepseducatie-programma, waarbij overigens ook steeds de partner uitgenodigd werd. $68 \%$ bood de mogelijkheid voor een individueel consult door een diëtiste en $17 \%$ voor individuele psychosociale hulp door de maatschappelijk werker. In $56 \%$ konden patiënten doorverwezen worden voor ergotherapie. 


\section{Tabel $\mathrm{V}$}

Hartrevalidatie in Noord-Amerika en Australië

\begin{tabular}{|c|c|c|c|c|}
\hline Oniderzoek & $x$ & $X \| N$ & $X V$ & $x \vee !$ \\
\hline Land & $\begin{array}{l}\text { Wirginia/ } \\
\text { Werentigde } \\
\text { Staten }\end{array}$ & $\begin{array}{l}\text { Verenigde } \\
\text { Staten }\end{array}$ & $\begin{array}{l}\text { Ontario } \\
\text { Canada }\end{array}$ & Australie \\
\hline Onderzoekers & Wolle ea & $\begin{array}{l}\text { Southard } \\
\text { Broyden }\end{array}$ & Wolfe ea & Worcester \\
\hline Jaar van onderzosk & 1983 & 1989 & 1985 & $1984 / 85$ \\
\hline $\begin{array}{l}\text { Onderzoeks- } \\
\text { instrument }\end{array}$ & $\begin{array}{l}\text { schriftelijke } \\
\text { enquête }\end{array}$ & $\begin{array}{l}\text { schriftelike } \\
\text { enquete }\end{array}$ & $\begin{array}{l}\text { schriftelijke } \\
\text { enquete }\end{array}$ & $\begin{array}{l}\text { schriftelijke } \\
\text { enquête }\end{array}$ \\
\hline Respondenten & $\begin{array}{l}\text { artsen } \\
\text { verpleeglkundigen } \\
\text { Iysiotherapeulen }\end{array}$ & anbekend & $\begin{array}{l}\text { artsen } \\
\text { verpleegkundigen } \\
\text { fysiotherapeuten }\end{array}$ & $\begin{array}{l}\text { artsen } \\
\text { verpleegkundigen }\end{array}$ \\
\hline Respons & $90 \%$ & $58 \%$ & $86 \%$ & $100 \%$ \\
\hline Revallidatietase & 1.2 en 3 & $1 e n 2$ & 1,2 en 3 & 1 en 2 \\
\hline $\begin{array}{l}\text { Aantal } \\
\text { aangeschreven } \\
\text { instellingen }\end{array}$ & 49 & 202 & 43 & 153 \\
\hline $\begin{array}{l}\text { Onderzochte } \\
\text { programma- } \\
\text { onderdelen }\end{array}$ & alle & $\begin{array}{l}\text { psychosociale } \\
\text { aspecten }\end{array}$ & alle & alle \\
\hline Patientgegevens & beperkt & nee & beperkt & boperkt \\
\hline
\end{tabular}

\section{Commentaar}

Delenprogramma's tijdens de mobilisatie blijken in Australië redelijk algemeen te zijn, maar ze worden doorgaans door verpleegkundigen gedaan. Daarentegen is de revalidatie na ontslag nog maar nauwelijks ontwikkeld. Het is verder onduidelijk in welke mate wan de diverse faciliteiten gebruik gemaakt wordt. Concrete aantallen zijn namelijk niet beschikbaar. Niettemin is dit het meest uitgebreide en degelijke onderzoek naar fase 1 en 2 dat buiten Nederland gedaan is. En ook hier is de conclusie op haar plaats dat de revalidatie van hartpatiënten in Australiê nog van zeer beperkte omvang is. 


\subsection{DISCUSSIE}

\subsubsection{Algemeen}

Het ontbreekt aan een coherente en het hele zorgtraject voot hartpatienten onvattende visie wat de doelstellingen moeten zijn, hoe de zarg georganiseerd dient te worden. welke patiënten in aanmerking komen en hoe het programma eruit dient te zien. Zowel in binnen-als buitenland ligt in de praktijk de nadruk op fysieke training cq conditietraining. Het alledaags functioneren van de patiënt voor het incident word niel als uitgangspunt genomen voor de revalidatie. Ook secundaire preventie komt nauweliks aan bod. Internationaal is opmerkelik weinig gepubliceerd over inventariserend onderzoek van de hartrevalidatie. Opvallend is dat bij het zoeken via de index Medicus geen enkele studie is gevonden! Dit zegt waarschijnlijk iets over het geringe belang dat gehecht wordt aan revalidatie. Het blift overigens onduidelijk hoe het staat met de hartrevalidatie in de landen die niet gerapporteerd hebben.

In Nederland is naar verhouding veel inventariserend onderzoek gedaan, gemiddeld van behoorlijke kwaliteit. Gepubliceerd onderzoek in andere landen toont een sterk wisselende kwaliteit. In Europa is vooral door West-Duitsland bericht over sportgroepen voor ex-hartpatiënten. Van Frankrijk, Spanje, Portugal, Oostenrijk, Zwitserland, Griekenland, de voormalige Oostblok-landen en de voormalige Sowjet-Unie zijn geen inventarisatiestudies bekend, van Noord-Amerika (Verenigde Staten en Canada) slechts enkele fragmentarische onderzoeken, van Midden-en Zuid-Amerika is niets bekend, en ook niet van landen uit Azië en Afrika. In Australië is een goede en meer omvattende studie gepubliceerd.

In geen enkele studie komt het helle, in drie fasen te onderscheiden zorgtraject voor hartpatiënten in zijn onderlinge samenhang aan bod. Overigens is een aantal van de gehouden enquêtes al behoorlijk gedateerd, waardoor het mogelijk is dat de situatie in de betreffende landen inmiddels is weranderd.

\subsubsection{Inhoudelijke beschouwingen}

\section{Mobilisatie tijdens de ziekenhuisopname}

Revalidatie tijdens opname (=fysieke reactivering tot ADL-niveau) staat inhoudelijk niet ter discussie. Er is overigens geen onderzoek bekend naar het effect van revalidatie in deze fase. Het is relatief eenvoudig te organiseren binnen het ziekenhuis en de kosten zijn relatief laag. Het meest voorkomende programmaonderdeel is fysieke training. In Nederland wordt dit in nagenoeg alle ziekenhuizen gegeven, in het buitenland is dat lang niet altijd het geval. In situaties waar revalidatie nog in de kinderschoenen staat, worden de oefenprogramma's tijdens de mobilisatie vaak door de verpleging begeleid.

Overigens blijit, in zowel binnen- als buitenland, onduidelijk hoeveel en welke patiënten daadwerkelijk in deze fase gerevalideerd worden en bovendien of er nog andere programma onderdelen dan alleen Iysieke training aangeboden worden. Zo zou er een 
stant gemaakt dienen te worden met voorlichting en secundaire preventie. Ook zou er op afroep psychosociale hulp in te roepen moeten zijn.

\section{Revalidatie na ontslag uit het ziekenhuis}

Hartrevalidatie na ontslag is de meest onderzochte fase in het zorgtraject, zowel in Nederland als daarbuiten. Doel hiervan is enerzijds fysiek en psychosociaal herslel en anderzijos verandering van risicogedrag. In de praktijk bestaat revalidatie vooral uit conditietraining.

Ook in deze fase blikt de nadruk eenzijdig op de fysieke reconditionering, zoals uit het belang van de inspanningstest blikt, te liggen. Meestal is de enige doelstelling een verbetering van de fysieke belastbaarheid, soms wordt ook herstel van psychische en sociale facetten nagestreefd. De doelstelling dat de patiënt zijn normale leven weer kan gaan leiden wordt uit het oog verloren. Doorgaans is echter het enige beschikbare middel hiertoe fysieke training. In feite wordt hiermee conditieverbetering beoogd. Secundaire preventie, een tweede doelstelling, komt nauwelijks aan bod en zeker niet op een systematische manier.

Op het gebied van de organisatie blijken de volgende mogelijkheden aanwezig te zijn: klinische revalidatie, poliklinische revalidatie in een daartoe gespecialiseerde afdeling, en een beperkt poliklinisch programma in hetzelfde ziekenhuis als waar de opname heeft plaatsgevonden. In sommige landen, zoals West-Duitsland, wordt alleen klinische revalidatie in speciale klinieken gegeven. In andere landen, zoals Australië, Noord-Amerika en Engeland wordt uitsluitend een beperkt poliklinisch programma aangeboden in het opnameziekenhuis. Nederland kent het gehele scala aan mogelijkheden. Een adequate en systematische indicatiestelling voor de verschillende wormen van revalidatie ontbreekt echter, zodat het van toevallige factoren afhangt welke vorm wan revalidatie de patiënt krijgt.

Ook is niet bekend hoeveel en welke patiënten in de verschillende revalidatievormen terechtkomen, noch op grond waarvan. In enkele landen, waaronder Nederland; is globaal bekend, op basis van schattingen, hoeveel patiënten gerewalideerd worden. Dit geldt ook voor een aantal patiëntkenmerken, zoals leeftijd, geslacht en diagnose.

\section{Onderhoudsfase: patiẻnteninitiatieven}

Nazorgactiviteiten hebben tot doel het herstel en de ingezette verandering van risicogedrag voort te zetten cq vast le houden. In feite is hier ook het centrale onderdee fysieke training cq conditietraining. Het is zeer de vraag of dit voldoende is om de genoemde doelstellingen te realiseren.

In een aantal studies wordt geen onderscheid gemaakt tussen de verschillende fasen van hartrevalidatie: vaak lopen revalidatie na ontslag uit het ziekenhuis en de nazorg in elkaar over. In deze fase is de bemoeienis van de regullere gezondheidszorg minimaal. De patiënt onderneemt op eigen initiatief activiteiten die het effect van de revalidatie dienen te continueren. Hier zou wel enige sturing cq advisering van belang zijn. Cardioloog en huisarts kumnen hier een belangrijke rol spelen. 
Qua organisatie valt de nazorg, in ieder geval in Nederland, buiten de reguliere gezondheidszorg en is zij athankelijk van particulier initiatief. Er zijn overigens slechts twee landen die onderzoek naar nazorg hebben gedaan: het voonmalige West-Duitsland en Nederland. Beide landen hebben een uitgebreid netwerk van sportclubs. In West-Duitsland is, van het hele zorgtraject, alleen de nazorg in de vorm van de elname aan (speciale) sportgroepen uitgebreid geinventariseerd. Daar bestaat de opvatting dat sportclubs voor een deel van de hartpatienten direct na ontslag uit het ziekenhuis ook een goede revalidatie kunnen bieden. In Nederland hadden en hebben sportclubs soms dezelfde functie, met name in die regio's waar geen revalidatie na ontslag uit het ziekenhuis gegeven wordt.

Bij de nazorg vormen sportieve activiteiten blikbaar het belangrijkste element. Dit is in leder geval het enige onderdeel van de nazorg waarnaar onderzoek is uitgevoerd. Onduidelijk blifft of er ook andere programma-onderdelen bestaan en zo ja in welke mate en door wie er gebruik van gemaakt wordt. Uitgaande van de doelstelling van deze fase in het zorgtraject ligt het voor de hand dat ook andere behandelonderdelen hier een rol krijgen.

De aamtallen en kenmerken van patiënten die aan sportgroepen deelnemen, zijn zowel van West-Duitsland als van Nederland redelijk bekend en zijn voor beide landen wergelijkbaar. In Nederland komt 13\% van de hartpatienten die het ziekenhuis verlaten, terecht in zo"n sportgroep, voor West-Duitsland geldt thetzelfde (Schäperclaus ea, 1991).

\subsubsection{Methoden van onderzoek}

Voor vrijwel elke in dit hoofdstuk behandelde studie, is de schriftelike enquête gebruikt als onderzoeksmethode. Een vergelijking van de diverse schriftelijke enquêtes leert dat zij hun beperkingen hebben. De data zilin doorgaans afkomstig van de eigen afdeling; sociale wenselijkheid kan de verschafte data vertekenen. De dataverzameling is retrospectief, wat een minder nauwkeurig beeld oplevert; het zijn meestal schaltingen.

De enquêtes zinn wooral gericht op de organisatie van hartrevalidatie en op de progranmaonderdelen. Hoewel een globale indruk van het aantal patienten word verkregen. blijt onduidelijk welke patiënten gerevalideerd worden en welke programma-onderdelen ze aangeboden krijgen. De gegevens hangen af van degene die de enquête invult.

Sterke punten zijn: inzicht en cijfers zijn op een snelle manier (globaal) beschikbaar. Er kan gemakkelijk een groot gebied bestreken worden. Het is een gepast middel om organisatie, faciliteiten en beschikbare programma-onderdelen te inventariseren.

In één onderzock is de mondelinge enquête toegepast. Deze aanpak is met name geschikt om een gedetailleerd inzicht te krijgen in een of enkele onderdelen van de hartrevalidatie. Nadelig is dat deze methode relatief veel tijd kost, en daardoor moeilik grootschalig kan worden toegepast. De respons is doorgaans hoog.

Overigens zijn het doorgaans artsen, verpleegkundigen en fysiotherapeuten die de gegevens aangeleverd hebben, hetgeen hel werschafte beeld van het zorgtraject woor hartpatiënten vertekend kan hebben. 


\subsubsection{Consequenties voor het eigen onderzoek}

Er dient ook onderzoek gedaan te worden naar de samenhang en overgang tussen de drie fasen van het zorgtraject. Vandaar dat in deze dissertatie al de drie fasen onderzocht worden. De diversiteit van revalidatievormen in de periode na ontslag uit het ziekenhuis vraagt eveneens am een verklaring. Quantitatieve gegevens ontbreken of zijn niet meer actueel te noemen. Het betreft type zorg, de organisatie, programma-onderdelen en patiëntaantallen en kenmerken.

Om de nauwkeurigheid en betrouwbaarheid van de gegevens te verhogen, zullen in dit registratie onderzoek, naast retrospectieve, ook prospectieve gegevens verzameld worden. De respondenten zullen de bij de revalidatie betrokken disciplines zijn. Zoals in het vooratgaande reeds gesteld zal dit waarschilnlijk een vertekening opleveren: zij zullen geneigd zijn de zaken mooier voor te stellen dan ze in werkelijkheid zijn. De verwachting is dat middels prospectieve gegevensverzameling dit effect verkleind kan worden en tot een aanvaardbaar niveau gereduceerd wordt.

\subsection{CONCLUSIES}

Van Nederland is bekend dat het (in vergelijking met dat deel van het buitenland dat geënquêteerd heeft) een uitgebreid netwerk van faciliteiten beschikbaar heeft voor de revalidatie van de hartpatiënt. Er is, eveneens in vergelijking met het buitenland, veel enquête-onderzoek verricht van redelijke tot goede kwaliteit. Zowel in binnen-als buitenland is fysieke training het centrale onderdeel van revalidatie. 


\section{HOOFDSTUK 3}

\section{Mobilisatie tijdens opname in het ziekenhuis}

\subsection{INLEIDING}

In dit hoofdstuk wordt verslag gedaan van inventariserend onderzoek naar de mobilisatie van hartpatiënten tijdens de ziekenhuisopname. De twee gebruikte onderzoeksmethoden waren: de schriftelijke enquête en de individuele patiëntenregistratielijsit.

\subsection{VRAAGSTELLING}

Met de schriftelijke enquête werd onderzocht: (a) hoeveel en welke ziekenthuizen coronaire hartpatiënten revalideerden tijdens de opnamefase, (b) welke disciplines bij de revalidatie betrokken waren en welke behandelonderdelen toegepast werden. (c) hoeveel en welke patiënten (aantal, leeftij, geslacht, indicatie, uitvallers) gerevalideerd werden.

Met behulp van de individuele patiëntenregistratielijsten werd getracht de volgende vragen te beantwoorden: (a) hoeveel en welke patienten maken lijdens ophame en na ontslag gebruik van welke behandelonderdelen? (b) zijn de patientgegevens verkregen via de schrifteligke (retrospectieve) enquête betrouwbaar?

\subsection{METHODEN}

De schriftelijke enquête over het jaar 1988 (zie bijlage ly werd in het voorjaar van 1989 opgestuurd naar 151 ziekenhuizen, waarvan bij de Nederlandse Hartstichting bekend was dat ze hartpatiënten opnamen. De contactpersonen voor de enquête waren doorgaans fysiotherapeuten.

Benaderd werden 138 algemene ziekenhuizen met een cardiologische/interne afdeling. 4 algemene ziekenhuizen met zowel een afdeling cardiologie als een afdeling cardiochi. rurgie, 1 categoraal ziekenhuis met een afdeling cardiochirurgie, 7 academische ziekenhuizen mel zowel een afdeling cardiologie als een afdeling cardiochirurgie, en 1 
academisch ziekenhuis met alleen een afdeling cardiologie. In totaal ging het om 150 atdelingen cardiologie/interne geneeskunde en 12 afdelingen cardiochirurgie. Indien er nazes weken nog geen respors was, volgde een schriftelike herinnering.

In 1988 werd aan de hiervoor genoemde 151 ziekenhuizen de mogelijkheid geboden om, met behulp van speciale registratielijsten (zie bijlage 11), individuele gegevens van hartpatiënten te verzamelen omtrent hun revalidatie tijdens en na de opname. De lijsten dienden niet alleen als registratiemiddel var prospectieve gegevens ten behoeve van het onderhavige onderzok, maar konden ook als zodanig gebruikt worden woor de betrokken afdelingen zelf.

Er zijn voor dit onderzoek 13 computers ter beschikking gesteld door de Nederlandse Hartstichting. Zij dienden naar evenredigheid verdeeld te worden over het land, en tussen erkende en niet-erkende afdelingen. Tenminste één ziekenthuis met cardiopulmonale chirurgie moest ook bedeeld worden. De uitverkoren afdelingen moesten een voldoende aantal patiënten behandelen, en gemotiveerd zijn om te registreren.

De ziekenhuizen die een computer kregen, verplichtten zich data te verzamelen en de gegevens geanonimiseerd ter beschikking te stellen. Daarnaast konden ziekenhuizen, die niet in aanmerking kwamen voor een computer, de registratielijsten plus het bijbehorende computer-software-programma gratis bestellen. De lijsten, de programmatuur en de computers werden begin 1988 verzonden, met het verzoek alle patienten te registreren die in dat jaar met revalidatie startten. De gegevens waren medio 1989 binner.

\subsection{RESULTATEN}

\subsubsection{Respons}

De respons van de schriftelijke enquête was matig: slechts 56 van de 151 ziekenhuizen $(37 \%)$ reageerden, ook na herhaald verzoek tot medewerking. Behalve het categorale ziekenhuis (met alleen een aldeling cardiochirurgie), hadden alle 55 andere ziekenhui. zen (52 algemene en drie academische) een afdeling cardiologie. Twee van de drie academische ziekenhuizen en één algemeen ziekenhuis hadden daarnaast tevens een afdeling cardiochirurgie.

De registratielijsten, gebruikt door 14 algemene ziekenhuizen en éen academisch ziekenhuis (met afdeling cardiochirurgie), leverden bruikbare gegevens op wan in totaal 4375 patiènten.

\section{4 .2 Onderzoeksgegevens}

In het navolgende zuilen de resultaten van de schriftelijke enquête en van de registratielijsten gezamenlijk gepresenteerd worden. In die gevallen dat van een variabele zowel 
enquête- als registratiegegevens beschikbaar waren, is gekozen voor de laatste, omdat deze gegevens gebaseerd zijn op het registreren van de concrete gang van zaken in de revalidatie, en daardoor naar verwachting betrouwbaarder zijn.

\section{Ziekenhuizen}

54 van de 56 ziekenhuizen die reageerden op de schriftelijke enquête, gaven hun hartinfarct- en hartoperatiepatiënten inderdaad fysiotherapie tijdens de opname. De vraag wanneer gestart werd met het geven van deze therapie, werd door 39 ziekenhuizen beantwoord: $36 \%$ startte reeds voor $1975,38 \%$ tussen 1976 en 1980 en $26 \%$ na 1980.

\section{Disciplines en programma-onderdelen}

\section{Disciplines}

Gemiddeld waren op een of andere manier per ziekenhuis zes disciplines bij de revalidatie betrokken, waaronder meestal de cardioloog en de verpleegkundige, alsook de fysiotherapeut (tabel I). Van de psychosociale sector was de maatschappelijk werker het meest vertegenwoordigd.

\section{Tabell}

Disciplines betrokken bij de revalidatie tijdens opname*

\begin{tabular}{ll}
\hline Disciplines & Ziekenhuizen $(\mathrm{N}=55)$ \\
\hline Cardioloog & $86 \%$ \\
Revalidatiearts & $39 \%$ \\
Arts/internist & $27 \%$ \\
& \\
Fysiotherapeut & $80 \%$ \\
Verpleegkundige & $71 \%$ \\
Diëtiste & $66 \%$ \\
Maatschappelik werker & $86 \%$ \\
Klinisch psycholoog & $56 \%$ \\
\hline
\end{tabular}

"Op basis van enquêtegegevens.

In tweederde van de ziekenhuizen vond eenmaal per week teamoverleg plaats; in een kwart (alle aigemene ziekenhuizen met alleen een cardiologische/interne afdeling) gebeurde dat niet of slechts incidenteel. Het team bestond meestal uit een cardioloog, een verpleegkundige en een fysiotherapeut; in ongeveer de helft van de ziekenhuizen was ook een maatschappelijk werker aanwezig bij het overleg (NVFH, 1988). De besprekingen gingen vooral over de individuele patientenvoortgang en in mindere mate over beleidsaspecten. 


\section{Tabel II}

Start fysiotherapie na opname*

\begin{tabular}{|c|c|c|c|}
\hline \multirow[t]{2}{*}{ Indicatie } & \multirow{2}{*}{$\begin{array}{l}\text { Zugeranzen } \\
\text { (amital) }\end{array}$} & \multicolumn{2}{|c|}{ Start na opname (in dagen) } \\
\hline & & (gemiddeld) & (spreiding) \\
\hline Iniarct & $(N=39)$ & 2,4 & $1-5$ \\
\hline Bypass & $(N=21)$ & 1,8 & $0-7$ \\
\hline PTCA & $(N=1 B$ & 1,3 & $0 \cdot 3$ \\
\hline
\end{tabular}

* Op basis van enquêtegegevens.

\section{Tabel III}

Inhoud fysiotherapie tijdens opname (na individuele mobilisatie)"

\begin{tabular}{ll}
\hline Programma-onderded & Ziekenhuzen $(\mathbb{N}=44)$ \\
Fietsergometer & $64 \%$ \\
Oefenzaal & $55 \%$ \\
Ontspanningsoeferingein & $32 \%$ \\
Sport en spel & $30 \%$ \\
Curcultiraining & $12 \%$ \\
Loopband & $9 \%$ \\
\hline
\end{tabular}

* Op basis van enquėtegegevens.

\section{Mobilisatie}

De tijdsduur tussen incident en start van de fysiotherapie bedroeg bil de helft van de patiënten minder dan drie dagen, bij $40 \%$ vier tot negen dagen en bij $10 \%$ tien dagen of langer (zie tabel II). Vroege start van de revalidatie vond mel name plaats bij de infarctpatiênten (gemiddeld vier dagen) en de patiënten uit de restcategorie (gemiddeld drie dagen); bij de meeste operatiepatiënten startte de fysiotherapie vanaf de vierde dag (gemiddeld zes dagen) na de opnamedag. Dit gold zowel voor de algemene ziekentuizen als voor het academisch ziekenhuis met de cardiochirurgie-afdeling.

Gemiddeld werden per patiënt negen fysiotherapiebehandelingen gegeven, één behan. deling per dag. Opvallend is dat de operatiepatiênten gemiddeld slechts vijf behandelingen kregen, in het operatieziekenhuis was dit gemiddeld slechts 3,5. De veelal vroege overolaatsting naar het verwijzende ziekenhuis zal hiervoor de verklaring zijn. De meeste ziekenhuizen hanteerden geen expliciete leeftijdsgrens voor fysiotherapie tijdens de opname. Drie deden dat wel: genoemd werden 65 en 80 jaar.

Patiénten werden de eerste dagen individueel gemobiliseerd op de CCU/IC of de observatieatdeling. Begonnen werd met oeteningen op bed, gevolgd door ADL-en loopoefeningen. Indien de patient weer redelik ter been was, werd de behandeling meestal in groepsverband voortgezet in de oefenzaal (tabel III). Het programma bestond 


\section{Tabel IV}

Redenen voortijdig stoppen met revalidatie

\begin{tabular}{lc}
\hline Redenen & Patiènten (Ne429) \\
\hline Overlijden & $22 \%$ \\
Andere cardiale klachten & $18 \%$ \\
Hantoperatie & $8 \%$ \\
PTCA & $7 \%$ \\
Andere lichamelije klachten & $11 \%$ \\
Weigering/desinteresse & $5 \%$ \\
Overige & $29 \%$ \\
Totaal & $100 \%$ \\
\hline
\end{tabular}

* Op basis van patiëntenregistratielijsten: 10\% van het totaal aantal gerevalideerde patienten stopte voortijdig ( $N=3956)$.

\section{Tabel V}

Aantal patiënten dat een inspanningstest krijgt rond ontslag naar diagnosegroep*

\begin{tabular}{lll}
\hline Indicatie & Patienten met test $(\mathrm{N}=1151)$ & Spreiding per ziekenhuis \\
\hline Infarct & $668(28 \%)$ & $3-75 \%$ \\
Operatie & $331(27 \%)$ & $0-77 \%$ \\
Rest & $152(14 \%)$ & $0-50 \%$ \\
\hline
\end{tabular}

* Op basis van patièntenregistratielijsten; $25 \%$ van alle patiënten kreeg een inspanningstest $(N=4771)$.

vrijwel steeds uit fietsen, ontspanningsoefeningen en sport \& spel. Daarnaast werd individueel vaak traplopen geoefend. Van alle gerevalideerde patiënten kreeg $79 \%$ het standaard mobilisatie-programma van het behandelende ziekenhuis, $19 \%$ een individueel toegespitst programma.

Aantal patienten voartijdig gestopt met fysiotherapie

$10 \%$ van alle patiënten moest voortijdig athaken, relatief weinig operatiepatiênten ( $7 \%$ ) en relatief veel patiënten uit de categorie "overige coronaire hartpatiënten" (12\%). Bij de meesten gebeurde dit al in the begin van de therapie. De belangrijkste redenen waarom gestopt werd, waren: overlijden (22\%), cardiale klachten, of andere lichamelijke klachten (tabel $\| \mathrm{V})$.

\section{Inspanningstest}

lets meer dan de helft van alle ziekenhuizen gaf aan bij infarctpatienten in principe oen imspanningstest te doen tijdens de opname of in de periode direct na ontslag.

In totaal bleek slechts een kwart van alle onderzochte patiënten van ziekenhuizen die zo'n test in het programma hadden rond het ontslag, daadwerkelijk getest te zijn: $28 \%$ van de infarctpatiënten, $27 \%$ van de operatiepatiénten en $14 \%$ van de patienten uit de 
restcategorie. Hetaantal gerevalideerde patiënten dat een inspanningsonderzoek kreeg. varieerde sterk per ziekenhuis: wan 0 to $67 \%$ (tabel $V$ ).

\section{Voorlichting}

In een aantal ziekenhuzen werd het videoprogramma van de Nederlandse Hartstichting "Een nieuw begin" gedraaid voor de patiênten en hun eventuele partners. In $12 \%$ van de ziekenhuizen kregen de patiënten een speciaal gepland voorlichtingsgesprek. Sporadisch vond dit onderhoud groepsgewijs plaats, meestal was hel een individueel gesprek met de patient en zijn/haar eventuele partner. Bij de overige $88 \%$ werd voorlichting minder gestructureerd gegeven tijdens gesprekken met hulpverleners, onder andere bij visites, tijdens de oefeningen en de verzorging, en bij het antslag. De disciplines die het meest aan voorlichting deden, waren: cardioloog, verpleegkundige. fysiotherapeut en diëtiste. Onduidelijk is of hier ook leettijdsgrenzen gehanteerd worden

\section{Individuele consulten}

In de meeste ziekenthuizen bestond de mogelijkheid individuele psychosociale consulten aan te vragen. Uit tabel I blijkt dat er doorgaans een maatschappeiijk werker (86\%) en/of klinisch psycholoog (56\%) beschikbaar waren voor voorlichting, crisisinterventie of counseling en advisering. Een diëtiste kon in tweederde van de ziekenhuizen ook geconsulteerd worden.

\section{Patiëntgegevens}

Aantal

Per afdeling cardiologie werden gemiddeld 183 patiënten per jaar gerevalideerd, waarvan $79 \%(=145)$ na hartintarct, $5 \%$ na CABG en $1 \%$ na klepoperatie, en $15 \%$ overige diagnosen (zie tabel VI). In de hantchirurgische centra werden nagenoeg alle patienten na $C A B G$ en klepoperatie aldaar gerevalideerd, behoudens patiënten met ernstige complicaties.

\section{Indicatie, geslacht en leeftijd}

$54 \%$ van de gerevalideerde patiënten had een infarct, $23 \%$ onderging een operatie en $23 \%$ behoorde tot de restcategorie (angina pectoris. PTCA of dreigend infarct) (tabel VII). $70 \%$ van de gerevalideerde patiënten was man (tabel VII). De meeste patiënten ( $56 \%$ ) waren tussen de 50 en 70 jaar oud, $15 \%$ was jonger dan 50 jaar en $29 \%$ ouder dan 70 jaar (tabel VII). Naarmate de leeftijd vorderde, was het percentage vrouwen hoger: bij de leeftijdscategorie tot 50 jaar was dat $19 \%$, tussen de 50 en 70 jaar $26 \%$ en boven de 70 jaar zelfs $43 \%$.

\subsection{DISCUSSIE}

Ondanks de lage respons op de enquête is deze studie om meerdere redenen uniek: in Nederland is nog nooit zo'n omvangrijk onderzoek gedaan naar revalidatie activiteiten 


\section{Tabel VI}

Aantal gerevalideerde patiënten tijdens opname per diagnosegroep en type afdeling*

\begin{tabular}{lccccc}
\hline Afdeling & Infarct & CABG & Klep & Rest & Totaal \\
\hline $\begin{array}{c}\text { Cardiologie } \\
(N=40)^{*}\end{array}$ & 5.837 & 368 & 56 & 1.058 & 7.319 \\
$(79 \%)$ & $(5 \%)$ & $(1 \%)$ & $(15 \%)$ & $(100 \%)$ \\
Hantchirurgie & - & 1.600 & 400 & - & 2.000 \\
$(\mathbb{N}=2)^{*}$ & & $(80 \%)$ & $(20 \%)$ & & $(100 \%)$ \\
Totaal & 5.837 & 1.968 & 456 & 1.058 & 9.319 \\
$(\mathbb{N}=42)^{*}$ & $(63 \%)$ & $(21 \%)$ & $(5 \%)$ & $(11 \%)$ & $(100 \%)$ \\
\hline
\end{tabular}

* Op basis van enquëtegegevens.

\section{Tabel VII}

Indicatie, leeftijd en geslacht van tijdens de opname gerevalideerde patiënten ( $N=4375)^{*}$

\begin{tabular}{|c|c|c|c|c|c|c|c|c|c|}
\hline & & \multicolumn{2}{|c|}{$\begin{array}{l}<50 \text { jaar } \\
(15 \%)\end{array}$} & \multicolumn{2}{|c|}{$\begin{array}{l}50-69 \text { jazr } \\
(56 \%)\end{array}$} & \multicolumn{2}{|c|}{$\begin{array}{l}\geq 70 \text { jaar } \\
(29 \%)\end{array}$} & \multicolumn{2}{|c|}{$\begin{array}{l}\text { Totaal } \\
(100 \%)\end{array}$} \\
\hline & & $M$ & V & $M$ & V & $M$ & V & $M$ & V \\
\hline Inlanct & 2.362 & $97 \%$ & $13 \%$ & $78 \%$ & $22 \%$ & $61 \%$ & $39 \%$ & $74 \%$ & $26 \%$ \\
\hline Operatie & 1.047 & $72 \%$ & $28 \%$ & $73 \%$ & $27 \%$ & $56 \%$ & $44 \%$ & $70 \%$ & $30 \%$ \\
\hline Rest & 966 & $76 \%$ & $24 \%$ & $66 \%$ & $34 \%$ & $49 \%$ & $51 \%$ & $61 \%$ & $39 \%$ \\
\hline Totaal & 4.375 & $81 \%$ & $19 \%$ & $74 \%$ & $26 \%$ & $57 \%$ & $43 \%$ & $70 \%$ & $30 \%$ \\
\hline
\end{tabular}

" Op basis van patientenregistratielijsten.

voor hartpatiënten tijdens de opname in het ziekenhuis. Van het buitenland is alleen een, overigens minder uitgebreide, studie bekend uit Australië. Ook het aantal met behulp van de individuele registratielijsten onderzochte patiënten is uniek.

\subsubsection{Dataverzameling en beperkingen}

De lage respons van de schriftelijke enquête kan mogelijk verklaard worden door het feit dat de enquête voornamelijk gericht was aan fysiotherapeuten, die soms een compleet overzicht van de revalidatie tijdens opname ontbeerden, en waarschijnlijk daarom niet reageerden. Oak het ontbreken van exacte gegevens binnen een afdeling, door een aantal respondenten aangegeven, kan een rol gespeeld hebben. Daarnaast kan er sprake zijn geweest van "enquête-moeheid": van 1984 tot en met 1988 zijn de ziekenhuizen de nodige malen over hartrevalidatie geënquêteerd (Maes ea, 1986; NVFH, 1988; Gutker de Geus, 1988; Dixhoorn van ea, 1988; Soons \& Bär, 1990a). De respons van $85 \%$ op de schriftelijke enquête in 1988 door Gutker de Geus (NVFH, 1988; Gutker de 
Geus, 1988) betreffende fysiotherapie tijdens de opnamefase, is zeer goed te noemen en onder andere te verklaren door het feit dat de vragen over het fysiotherapieprogramma gesteld werden door een fysiotherapeut aan vakgenoten, terwij bovendien geen patiëntenaantallen aan de orde kwamen.

De hoge non-respons betekent dat de nodige voorzichtigheid betracht dient te worden bij het doen van uitspraken over alle ziekenhuizen in Nederland, alleen op basis van onderhavige onderzoeksgegevens. Een beperking van hel onderzoek mef de registratielijsten is het ontbreken van vragen aangaande individuele consulten tijdens de opnamefase door diëtiste, maatschappelijk werker en klinisch psycholoog.

\subsubsection{Onderzoekspopulaties}

Van de 151 aangeschreven ziekenhuizen respondeerden er 56 op de schriftelije enquête: 51 ziekenhuizen met alleen een afdeling cardiologie en 5 operatieziekenhuizen. respectievelijk $37 \%$ (van de 139) en $42 \%$ (van de 12). Dit betekent dat beide typen ziekenhuizen zeer matig, maar wel redelik evenredig vertegenwoordigd waren in de respons. Dit kan een gunstige invloed hebben gehad op de juistheid van de gegevens.

De individuele patiëntenregistratielijsten leverden gegevens op over 2388 infarctpatiënten, 10\% van de totaalpopulatie (LMF/SIG, 1989) en over 1017 operatiepatiënten, 11\% van de totaalpopulatie (Begeleidingscommissie Hartchirurgie, 1989). Dit betekent dat de onderzoeksgroep een adequate steekproef lijkt te zijn van de Nederlandse populatie voor deze twee diagnosegroepen. 14 algemene ziekenhuizen met alleen een afdeling cardiologie en ến operatieziekenhuis stuurden de lijsten op, respectievelijk 10\% (van de 139) en $8 \%$ (wan de 12). Ook hier blijken beide typen ziekenhuizen redelijk evenredig vertegenwoordigd te zijn.

\subsubsection{Vergelijking van de resultaten van de twee onderzoeksmethoden}

De data van de schriftelijke enquête bleken vooral geschikt om een landelijk overzicht te krijgen van de revalidatie tijdens de opname. Dit bleek met name te gelden voor "instellingsgegevens" en "programma-onderdelen". Anders ligt dat voor de "patientgege. vens" uit de schriftelijke enquête. Slechts een deel van het toch al beperkt aantal responderende zlekenhuizen produceerde gegevens en deze werden in de meeste gevallen retrospectief (door middel van schattingen) genoteerd. wat maakt dat de betrouwbaarheid van de verstrekte data ongetwijfeld beperkt is. Om dit euvel te ondervangen, werd in 1988 gestart met prospectieve gegevensverzameling door middel van individuele patiëntenregistratielijsten. Een dergelijke benadering biedt tevens de mogelijkheid om enquête - en lijstgegevens van sommige variabelen met elkaar te vergeliken, bij die afdelingen die op beide manieren data aangeleverd hebben.

De woigende zes variabelen kwamen in aanmerking: "start fyslotherapie na opname", "aantal patienten dat voortijig gestopt is met fysiotherapie" "indicatie", "geslacht", "leeftijd" en "aantal gerevalideerde patiènten" (zie tabel VIII). Het moment van start volgens de patiëntenregistratielijstgegevens, in vergelijking met de gegevens van de enquête, lag beduidend later: bij infarctpatiënten gemiddeld respectievelijk 4 en 2,4 


\section{Tabel VIII}

Vergelijking van data uit de ziekenhuisfase verkregen met behulp van enquête en individuele patiëntenregistratielijst (IP)

\begin{tabular}{|c|c|c|c|}
\hline \multicolumn{2}{|l|}{ Variabelen } & \multirow{2}{*}{$\frac{\text { Enquête }}{342}$} & \multirow{2}{*}{$\frac{I P}{317}$} \\
\hline Aantal gerevalideerde patiënten per afdeling & & & \\
\hline Aantal dagen dat fysiotherapie start na opname & $\begin{array}{l}\text { intarct } \\
\text { operatie }\end{array}$ & $\begin{array}{l}2,4 \\
1,8\end{array}$ & $\begin{array}{l}4,0 \\
6,0\end{array}$ \\
\hline \multicolumn{2}{|c|}{ Percentage patiënten voortijig gestopt met fysiotherapie } & 7.5 & 7.5 \\
\hline Indicatie gerevalideerde patiënten & $\begin{array}{l}\text { intarct } \\
\text { operatie } \\
\text { rest }\end{array}$ & $\begin{array}{r}77 \% \\
7 \% \\
16 \%\end{array}$ & $\begin{array}{r}77 \% \\
9 \% \\
14 \%\end{array}$ \\
\hline Leeftijd gerevallideerde patiënten in jaren & $\begin{array}{l}0-50 \\
50 \\
70\end{array}$ & $\begin{array}{l}11 \% \\
54 \% \\
35 \%\end{array}$ & $\begin{array}{l}12 \% \\
54 \% \\
34 \%\end{array}$ \\
\hline Geslacht gerevallideerde patiënten & $\begin{array}{l}\text { Man } \\
\text { Vrouw }\end{array}$ & $\begin{array}{l}74 \% \\
26 \%\end{array}$ & $\begin{array}{l}75 \% \\
25 \%\end{array}$ \\
\hline
\end{tabular}

dagen na opname, en bij operatiepatiënten idem 6 en 1,8 dagen. Ten aanzien van de variabelen "aantal patiënten voortijdig gestopt met fysiotherapie", "indicatie", "aantal gerevalideerde patiënten", "geslacht" en "leeftijd" zijn er kleinere of geen verschillen. Concluderend kan gesteld worden dat er behoudens het startmoment van revalidatie geen grote verschillen te zien zijn tussen de data uit beide onderzoeksmethoden.

\subsubsection{Beschouwingen}

In het navolgende worden de onderzoeksresultaten vergeleken met reeds bekende cijfers uit binnen- en buitenland. Australië is het enige land buiten Nederland dat ook een gedegen studie heeft verricht naar de opnamefase.

Het aantal van 151 ziekenhuizen dat hartpatiënten opneemt, uitgangspunt van deze studie, is correct (Spaan \& van der Speld, 1990; NZI, 1989; NZI, 1990; Lorsheyd, 1990; LMR/SIG, 1989). Sinds 1979 , toen er 140 van dergelijke ziekenhuizen waren, is dit totaal dus nauwelijks meer gestegen (Weeda \& Visser, 1981). Het aantal cardiologische afdelingen bedraagt 134 (Klein Nulens ea, 1991), wat impliceert dat 16, waarschijnlijk kleine, ziekenhuizen de hartpatiënten op de aideling interne geneeskunde onderbrengen.

Conform de bevindingen uit deze studie constateerde ook de NVFH(1988) dat nagenoeg elk ziekenhuis een door fysiotherapeuten verzorgd mobilisatie-programma voor hartpatiënten kende: slechts drie van de 136 aan de NVFH-enquête deelnemende ziekenhuizen 
gaven geen fysiotherapie fijdens de opname. Op basis hiervan kan gesteld worden dal aan de belangrijkste doelstelling van de zorg voor hartpatienten tijdens de ziekenhuisopname, namelik reactivering, in Nedertand ruimschoots voldaan wordt.

In 1979 werd in Nederland in de meeste ziekerhuizen al aandach besteed aan actieve mobilisatie, reactivering en ADL-training (Weeda 8 Visser, 1981). Viel toen de begeleiding van de activiteiten, in de helft wan de ziekenhuizen, nog onder de zorg van verpleegkundigen, in 1988 was deze taak, in nagenoeg alle ziekenhuizen, inmiddels toebedeeld aan fysiotherapeuten, een ontwikkeling die erop wijst dat steeds vaker gespecialiseerde/professionele krachten worden ingeschakeld.

in 1984 had 69\% van de Australische ziekenhuizen die hartpatiënten opnamen een mobilsatie programma, grotendeels verzorgd door verpleegkundigen, helgeen betekent dat de professionalisering van de mobilisatie daar nog niet zo ver doorgevoerd is als in Nederland.

In veel ziekenhuizen kan een inspanningstest afgelegd worden, slechts een kwart van de patiënten krijgt echter zo'r test, bovendien variëert het aantal geteste patiënten per ziekenhuis enorm: van 0 tot $77 \%$. In Australië bestaat deze mogelikheid in ruim de helft van de ziekenhuizen, meestal worden ook daar slechts weinig patiënten daadwerkelijk getest. Exacte ciffers ontbreken echter. Onduidelijk is of de variatie veroorzaakt wordt door inhoudelijke dan wel financiële redenen. Het is wenselijk dat er onder medisch specialisten consensus bereikt wordt over op welk moment, welke patiënten, gelet op diagnose en eventuele complicaties, zon test dienen te krijgen.

Secundaire preventie staat vrijwel nergens op het programma, en van een systematische aanpak is helemaal geen sprake. Hierdoor wordt niet voldaan aan de doelstelling om reeds tijdens de opname een start te maken met voorlichting en verandering van risicogedrag (Wenger, 1979; Superko, 1985; Maeland \& Havik, 1987; Bär \& Vonken, 1990; Elderen van, 1991). In Australië bleek de situatie wat dat betreft beter te zijn: $18 \%$ van de ziekenhuizen verzorgde een groepsvoorlichtingsprogramma tijdens de opname.

De beschikbaarheid van psychosociale disciplines is fors toegenomen in vergelijking met 1979: toen was in ongeveer de helft van de ziekenhuizen een maatschappelijk werker beschikbaar en slechts in enkele een klinisch psycholoog (Weeda \& Visser, 1981). Dit wijst op een groelende aandacht voor en acceptatie van de psychosociale aspecten van revalidatie lijdens de opname.

Waarschijnlijk is het aantal diëtisten dat bil de zorg woor hartpatiënten is betrokken sterk toegenomen, omdat in het onderzoek van Weeda \& Visser, dat de situatie in 1979 beschreef. geen melding werd gemaakt wan de beschikbaarheid van een diëtiste tijdens de opname. Blijkbaar wordt het belang van gezonde voedingsgewoonten steeds sterker onderkend.

In Australië bleek in $84 \%$ van de ziekenhuizen een maatschappelijk werker beschikbaar, helgeen overeenkomt met de Nederlandse situatie; een klinisch psycholoog was slechts sporadisch le consulteren. In $71 \%$ was daarentegen een diëtiste beschikbaar. Onduidelijk was in hoeverre daadwerkelijk en systematisch van deze disciplines gebruik werd 
gemaakt. De indruk bestaat dat deze disciplines op ad hoc basis en weinig frequent ingeschakeld werden, ook al omdat ze meestal niel deemamen aan het teamoverleg. Het ontbreekt in Nederland aan consensus over de inbreng van deze disciplines, en ook aan een expliciete financiële structuur.

Per afdeling werden gemiddeld 196 patienten opgenomen na een intarct (LMR/SIG. 1989). waarvan er $33(=17 \%$ ) overleden in het ziekenhuis. Gezien de bevinding uit onderhavig onderzoek dat er 145 infarctpatiënten per afdeling gerevalideend werden, kan gekonkludeerd worden dat $74 \%$ van alle opgenomen intarctpatienten en $90 \%$ van alle infarctpatiënten die het ziekenhuis levend verlieten, gerevalideerd werden.

Het totaal aantal patiënten na CABG van hartchirurgische centra in Nederland bedroeg 8.283 en het totaal aantal klepoperaties 1.350 (Begeleidingscommissie Hartchirurgie. 1989). Gesteld kan dan ook worden dat $17 \%$ van alle patienten na CABG na terugplaatsing op de afdeling cardiologie van herkomst verder gerevalideerd werd, en $21 \%$ van de patienten na klepoperatie.

Uit cijfers van het LMR/SIG (1989) blijkt dat $40 \%$ van de opgenomen inlarctpatiënten ouder was dan 70 jaar, terwijl $29 \%$ van de gerevalideerde patiënten ouder is dan 70 jaar. De patiënten die niet gerewalideerd werden zijn waarschinlijk de ouderen en degenen met zeer ernstige klachten en complicaties. Verder blijkt uit dezelfde cijfers dat $69 \%$ van de opgenomen hartinfarctpatiënten man was en $31 \%$ vrouw. De man-vrouw verdeling in de gerevalideerde populatie wa $74 \%$ respectievelijk $26 \%$. Dit verschil komt to uting in met name de groep patienten boven de 70 jaar: de geslachtsverdeling bij de opgenomen infarctpatienten was hier $54 \%$ respectievelijk $46 \%$ en die wan de gerevalideerde infarctpatienten $61 \%$ respectievelijk $39 \%$. Voor de opnamefase kan dan ook gesteld worden dat in verhouding ongeveer evenveel mannen als vrouwen in aanmerking kwamen voor revalidatie.

Uit bovenstaande cijfers kan geconcludeerd worden dat een zeer groot deel van de hartpatiënten tijdens opname gereactiveerd wordt.

\subsection{CONCLUSIES}

Het gaat hier om een eerste studie die een redelik betrouwbaar totaalbeeld geeft van de revalidatie van harfpatiënten tijdens de ziekenhuisopname. Bijna alle responderende ziekenhuizen gaven fysiotherapie tijdens de opname aan een zeer groot deel van hun patiënten, waardoor voldaan wordt aan de belangrijkste doelstelling van de zorg voor hartpatiënten tijdens de ziekenhuisopname. Een kwart van de patiënten kreeg een inspanmingstest op het einde van de opname of direct na ontslag. Inzet van diëtist, maatschappelijk werk en klinisch psycholoog gebeurde waarschijnlijk weimig en bovendien meestal op ad hoc basis. Systematische voorlichting ontbrak nagenoeg, waardoor niet voldaan wordt aan de doelstelling reeds tijdens de opname een start te maken met voorlichting en verandering van risicogedrag. 



\section{HOOFDSTUK 4}

\section{Revalidatie na ontslag uit het ziekenhuis}

\subsection{INLEIDING}

Hoe het staat met de revalidatie van hartpatiënten na ontslag uit het ziekenhuis, wordt in dit hoofdstuk beschreven. Bij het onderzoek werd gebruik gemaakt van mondelinge en schriftelijke enquêtes en van individuele patientenregistratielijsten.

Dit onderzoek kan gezien worden als een vervolg op de enquêtering van Van Dixhoorn ea $(1988)$.

\subsection{VRAAGSTELLING}

Ten aanzien van de revalidatie na ontslag uit het ziekenhuis werd getracht de volgende vragen te beantwoorden: (a) hoeveel en welke instellingen revalideren hartpatiënten, (b) welke disciplines zijn erbij betrokken en welke behandelonderdelen worden gegeven, (c) hoeveel en welke patiënten (aantal, leeftijd, geslacht, indicatie, uitvallers, verwijzingen) worden getevalideerd, (d) veranderingen in de tijd van bovengenoemde variabelen.

\subsection{METHODEN}

Op de eerste plaats zijn in de periode 1986-1989 in Nederland schriftelijke enquêtes gehouden (ekk jaar één). De enquêteformulieren werden steeds na afloop van het te enquêteren jaar opgestuurd naar de contactpersonen van de instellingen. De enquêtes uit 1988 en 1989 (zie bilage III) werden vereenvoudigd: instellingskenmerken en behandelonderdelen hoefden alleen genoteerd te worden indien er, in vergelijking met het jaar daarvoor, veranderingen waren opgetreden. Als de formulieren na ongeveer zes weken niet teruggestuurd waren, volgde een schriftelijke herinnering, indien nodig ook nog een telefonische. Alle gegevens waren medio 1989 binnen. Het betrof 115 afdelingen.

Op de tweede plaats heeft een mondelinge enquête plaatsgevonden in 1987/88 en betrof de toentertijd bij de anderzoekers bekende afdelingen ( $N=88$ ). Doel wan de mondelinge 
enquête was de middels de schriftelike enquête gevonden gegevens aan le wullen en te controleren. Verder werden detals gevraagd van het behandelprogramma, met name psychosociale zorg, voorlichting en klinische revalidatie dienden verduidelijk te worden. Ook diende hel interview ertoe atdelingen te motiveren om mee te werken aan het onderzoek. In principe kon het hele team bij het interview aanwezig zijn. Hel gesprek duurde gemiddeld éen uur.

Op de derde plaats werd in 1988 aan de toen bekende atdelingen de magelijkheid geboden via registratielijsten (zie bijlage II) prospectief individuele gegevens van patiënten te werzamelen, met als doel een antwoord te krijgen op de volgende vragen: (a) hoevee en wekk patiënten maken gebruik van welke behandelfaciliteiten? en (b) zijn de patientgegevens, verkregen via de enquêtes, betrouwbaar? Medio 1989 waren de gegevens binnen. Voor verdere intormatie over de patiëntenlijsten zie paragraal 3.3.

\subsection{RESULTATEN}

\subsubsection{Respons}

Van de 115 instellingen waarvan in 1989 bekend was dat daar hartrevalidatie na ontslag werd gegeven, hebben $111(97 \%)$ tenminste eemmaal op de schriftelijke enquêtes in de periode 1986-1989 gereageerd. $75 \%$ heeft minimaal tweemaal gerespondeerd. De contactpersonen, die ook de enquêtes invulden, waren doorgaans fysiotherapeuten $(75 \%)$ en artsen (16\%). Uit de gegevens van instellingen die meer dan éen keer gerespondeerd hebben, bleek dat de instellingskenmerken en programma-onderdelen over het tijdsbestek van vier jaar in vrijwel alle centra ongewizigd waren. Indien er verschillen waren, zijn de meest recente gegevens van de instellingen verwerkt in de resultaten. Patiëntkenmerken zijn per jaar berekend.

$92 \%$ van de 88 in 1987 bekende en benaderde instellingen was bereid mee te werken aan de mondelinge enquête, 7 instellingen weigerden. In 54 (67\%) afdelingen was één discipline, in de overige $27(33 \%)$ afdelingen waren twee of meer disciplines bij het interview aanwezig. Fysiotherapeut en arts waren hell meest vertegenwoordigd. Met behulp van de interviews werden de via de schriftelijke enquêtes verzamelde gegevens gecontroleerd en aangevuld. Daarnaast werd aanvullende intormatie verkregen in de vorm van protocollen, jaarverslagen en patiënteninformatiefolders. Ook werd zo het aantal bekende afdelingen vergroot.

15 afdelingen methartrevalidatie na ontslag hebben via de registratielijsten data geleverd betreffende 2.043 patienten. Het gaat am tien afdelingen met een fysiek reconditioneringsprogramma verbonder aan algemene ziekenhuizen, twee atdelingen met erkenning voor revalidatiedagbehandeling verbonden aan algemene ziekenhuizen en alledrie de afdelingen met erkenning voor klinische revalidatie na ontslag. 


\subsubsection{Onderzoeksgegevens}

In deze paragraaf worden de gegevens gepresenteerd van de schriflelike en mondelinge enquêtes, plus de resultaten van de individuele patientenregistratielijsten. Wamneer wan een variabele gegevens beschikbaar waren wia zowel de enquêtes als de individuele patiententijsten, is gekozen voor de data van de laatstgenoemde onderzaeksmethode, daar deze gegevens gebaseerd zijn op een registratie van de concrete gang van zaken en daardoor, naar verwachting, betrouwbaarder zijn dan de gegevens van de enquetes die gebaseerd zijn op schattingen. In de discussie zal hierop worden teruggekomen.

\section{Instellingen}

\section{Soorten instellingen}

Er bestaan in Nederland drie vormen van hartrevalidatie na ontslag:

(a) Kinische revalidatie: de patiënt wordt opgenomen en krijgt een multidisciplinair en geindividualiseerd revalidatieprogramma aangeboden. Deze worm van zorg werd verstrekt in twee revalidatiecentra (Haren en Hoensbroek) en in én algemeen ziekenhuis (Hilversum). Hierbij dient opgemerkt te worden dat met de klinische revalidatie in het Revalidatie Instituut Muiderpoort in 1988 is gestopt en dat anno 1992 de klinische revalidatieafdeling in Hilversum (Zonnestraal) is opgeheven. Daar staat tegenover dat er een nieuwe mogelijkheid gecreëerd is in Katwijk (Zeehospitium). Patiënten krijgen doorgaans een multidisciplinair, dagvullend programma. Naast fysieke training wordt expliciet aandacht besteed aan secundaire preventie. Verder bestaat de mogelijkheid voor individuele consulten van maatschappelijk werker, klinisch psycholoog en diëtiste. Overigens kunnen patiënten in deze instellingen tegelijkertijd poliklinisch revalideren.

(b) Revalidatiedagbehandeling: de patiënt krijgt een poliklinisch multidisciplinair programma aangeboden (Ziekenfondsraad, 1981). Naast een meestal groepsgewijs fysiek programma wordt ook aan secundaire preventie gedaan. Verder bestaat hier eveneens de mogelijkheid wan individuele consulten van maatschappelijk werker, klinisch psycholoog en diëtiste. Deze vorm van revalldatie vond toepassing in 25 instellingen: 7 revalidatiecentra en 18 algemene ziekenhuizen.

(c) Fysieke reconditionering, door afdelingen zonder erkenning voor revalidatiedagbe. handeling: de patiënt krijgt in principe alleen een poliklinisch fysiek programma aangeboden. meestal in groepsverband. Behandeling aldus gebeurde in 87 instellingen: 3 academische en 84 algemene ziekenhuizen.

Incidenteel werden hartpatiënten in perifere fysiotherapie praktijken behandeld (KNGF. 1990). Dit kan echter niet gezien worden als een vorm van revallidatie naast de genoemde drie.

$23 \%$ van de algemene en academische ziekenhuizen gal geen revalidatie na ontslag. De meeste van deze ziekenhuizen verwezen echter door naar een hiervoor erkend centrum. $77 \%$ van de instellingen had wel revalidatie na ontslag in huis, $70 \%$ in de vorm van fysieke reconditionering, $7 \%$ in de vorm van revalidatiedagbehandeling. 


\section{Tabell}

Jaar van start hartrevalidatie na ontslag naar soort afdeling

\begin{tabular}{llccc}
\hline $\begin{array}{l}\text { Stan } \\
\text { jatar }\end{array}$ & $\begin{array}{l}\text { Kin } \\
(N=3)\end{array}$ & $\begin{array}{c}\text { RDB* } \\
(N=25)\end{array}$ & $\begin{array}{c}F R^{* * *} \\
(N=80)\end{array}$ & $\begin{array}{c}\text { Totaal } \\
(N=108)\end{array}$ \\
\hline $1965-69$ & 1 & $1(4 \%)$ & 0 & $2(2 \%)$ \\
$1970-74$ & 1 & $11(44 \%)$ & $12(15 \%)$ & $24(22 \%)$ \\
$1975-79$ & 0 & $8(32 \%)$ & $30(38 \%)$ & $38(35 \%)$ \\
$1980-84$ & 1 & $5(20 \%)$ & $29(36 \%)$ & $35(33 \%)$ \\
$1985-88$ & 0 & $0(0 \%)$ & $9(11 \%)$ & $9(8 \%)$ \\
& $(100 \%)$ & $(100 \%)$ & $(100 \%)$ & $(100 \%)$ \\
\hline
\end{tabular}

"Kinische revalidatie; "* Fevalidatiedagbehandeling; "*." Fysieke reconditionering; \# op basis van enquëtegegevens.

\section{Startjaar hartrevalidatie}

Uit tabel I blijkt dat twee instellingen reeds voor de officiële start in 1970 hartrevalidatie toepasten. Drie instellingen voor klinische revalidatie waren er vanaf de start bij: Amsterdam, Haren en Hilversum.

De meeste afdelingen met erkenning voor revalidatiedagbehandeling zijn gestart tussen 1970 en 1976: zij kregen de financiële armslag om patienten multidisciplinair te behandelen. Na 1984 is er geen erkende afdeling meer bijgekomen omdat het erkenningenbeleid van de overheid stagneerde. Fysieke reconditionering van hartpatiënten wordt vergoed als fysiotherapieverrichting. Vanaf het begin van de jaren 70 tot medio 80 -er jaren is er een forse groei geweest van het aantal niet-erkende afdelingen. Het aantal groeit nog steeds, hoewel de laatste jaren mondjesmaat. Anno 1989 waren er 87 niet-erkende afdelingen voor hartrevalidatie.

\section{Spreiding over Nedertand}

De hartrevalidatie is in Nederland verdeeld over drie regio's (Dixhoorn van ea, 1988): Noord/Oost (provincies Groningen. Friesland, Overijssel en deel van Gelderland met als westgrens de Veluwe en als zuidgrens de Rijn). West (Noord-en Zuid-Holland, Utrecht en deel Gelderland) en Zuid (Limburg, Noord-Brabant, Zeeland en deel Gelderland) (tabel II).

Uit de inventarisatie blijkt dat etke regio een mogelijkheid had voor klinische revalidatie. In de praktijk blijkt dat met name naburige ziekenhuizen verwijzen voor klinische revalidatie, hetgeen inhoudt dat landelijk niet evenredig gebruik gemaakt wordt van deze mogelijkheid tot revalidatie. Gerelateerd aan het aantall inwoners kende regio Zuid de meeste hartrevalidatie-afdelingen, namelijk ongeveer tweemaal zoveel als de rest.

Daamaast is Nederland opgedeeld in 27 gezondheidsregio's ten behoeve van de intramurale gezondheidszorg (Spaan \& Speld van der, 1990). Wanneer het aantal instellingen per aantal inwoners van een gezondheidsregio als uitgangspunt wordt 


\section{Tabel II}

Spreiding van soorten afdelingen voor hartrevalidatie na ontslag uit het ziekenhuis over Nederland in 1988\#

\begin{tabular}{llllll}
\hline Regio & $\begin{array}{l}\text { Inwonersaantal } \\
\text { (miljoen) }\end{array}$ & $\begin{array}{l}\mathrm{Klin}^{*} \\
(\mathrm{~N}=3)\end{array}$ & $\begin{array}{l}\text { RDB** } \\
(\mathrm{N}=25)\end{array}$ & $\begin{array}{l}\text { FF** } \\
(\mathrm{N}=87)\end{array}$ & $\begin{array}{l}\text { Toraal } \\
(\mathbb{N}=115)\end{array}$ \\
\hline Noord & $4,1(28 \%)$ & 1 & $5(20 \%)$ & $21(24 \%)$ & $27(24 \%)$ \\
West & $6,5(44 \%)$ & 1 & $11(44 \%)$ & $31(36 \%)$ & $43(37 \%)$ \\
Zuid & $4,1(28 \%)$ & 1 & $9(36 \%)$ & $35(40 \%)$ & $45(39 \%)$ \\
Totaal & $14,7(100 \%)$ & $3(100 \%)$ & $25(100 \%)$ & $87(100 \%)$ & $115(100 \%)$ \\
\hline
\end{tabular}

"Klinische revalidatie; "Rewalidatiedagbehandeling: "*** Fysieke reconditionering; \# op basis van enquêtegegevens.

genomen, bleken met name de regio's Leiden en Den Haag relatief sterk ondervertegenwoordigd (tabel III). Regio 't Gooi had de meeste instellingen ter beschikking.

\section{Dïsciplines en programma-onderdelen}

\section{Disciplines}

Aan ledere afdeling waren een of meerdere artsen verbonden, die ofwel vast lid van het team of op afroep beschikbaar waren (tabel IV). Van de paramedische sector was de fysiotherapeut altijd aanwezig, niet verwonderlijk omdat fysieke training vrijwel steeds onderdeel van het programma was. Van belang hierbij is dat er een expliciete financieringsregeling voor fysiotherapie-verichtingen bestaat. In de psychosociale sector waren de maatschappelijk werker en de klinisch psycholoog de meest voorkomende disciplines. In 93\% van alle erkende afdelingen ( $\mathrm{klinisch}$ en revalidatiedagbehandeling) en $35 \%$ van alle niet-erkende vond wekelijks teamoverleg plaats. Bijna de helft van de niet-erkende afdelingen had echter geen regelmatig, gestructureerd overleg.

\section{Het fysieke programma}

14 van de 87 afdelingen gericht op fysieke reconditionering, een minderheid, hanteerden een, miet absolute, leeftijosgrens van 65,70 of 75 jaar.

De meeste instellingen gaven een standaard fysiek groepsprogramma dat door het merendeel van de patiënten ( $85 \%$ ) gevolgd werd. De rest kreeg, vanwege complexe fysieke cq medische problematiek, een individueel toegespitst programma. Met name in klinische afdelingen kregen veel patiënten een dergelijk programma aangeboden (39\%); voor afdelingen met fysleke reconditionering lag dat lager (13\%). Opvallend was het geringe percentage (3\%) patiènten dat in een erkende afdeling voor revalidatiedagbehandeling een individueel programma kreeg.

Het fysieke programma startte, voor zowel infarct- als operatiepatienten, gemiddeld ongeveer twee weken na ontslag, voor $11 \%$ var de patiënten gebeurde dat pas na zes of meer weken. 


\section{Tabel III}

Spreiding van soorten afdelingen voor hartrevalidatie na ontslag uit het ziekenhuis per gezondheidsregio in 1988

\begin{tabular}{|c|c|c|c|c|c|c|}
\hline \multirow[t]{2}{*}{ Regio } & \multirow[t]{2}{*}{$\begin{array}{l}\text { Aantal } \\
\text { inwonars }\end{array}$} & \multirow[t]{2}{*}{$\begin{array}{l}\text { Aantal } \\
\text { ziekenhuizen }\end{array}$} & \multicolumn{4}{|c|}{$\begin{array}{l}\text { Aantal instellingen met } \\
\text { revalidatie na ontslag }\end{array}$} \\
\hline & & & $\begin{array}{l}\mathrm{Klin} * \\
\mathbb{N}=3\end{array}$ & $\begin{array}{l}\mathrm{ROB}^{* *} \\
\mathrm{~N}=25\end{array}$ & $\begin{array}{l}\mathrm{FP}^{+\infty *} \\
\mathrm{~N}=87\end{array}$ & $\begin{array}{l}\text { Totaal } \\
N=115\end{array}$ \\
\hline 1. Groningen & 556.757 & 6 & 9 & & 3 & 4 \\
\hline 2. Friesiand & 599.104 & 6 & - & 1 & 3 & 4 \\
\hline 3. Drenthe & 436.586 & 5 & - & - & 4 & 4 \\
\hline 4. Zwolle & 472.014 & 5 & . & 1 & 4 & 5 \\
\hline 5. Twente & 569.704 & 5 & - & 2 & 2 & 4 \\
\hline 6. Stedendrienoak & 448.820 & 4 & - & 2 & 2 & 4 \\
\hline 7. Arrhem & 838.115 & 10 & . & 1 & 5 & 6 \\
\hline 8. Nimmegen & 432.086 & 3 & - & 1 & 3 & 4 \\
\hline 9. Unechi & 1.009 .929 & 13 & - & 3 & 7 & 10 \\
\hline 10. Flevoland & 193.739 & 2 & - & - & 2 & 2 \\
\hline 1. TGool & 252.643 & 4 & 1 & - & 3 & 4 \\
\hline 12. Alkmaar & 545.436 & 4 & - & $\|$ & 1 & 2 \\
\hline 13. Kennemerland & 375.562 & 7 & - & 1 & 2 & 3 \\
\hline 14. Amslerdam & 1.194 .754 & 12 & - & 1 & 5 & 6 \\
\hline 15. Leiden & 470.913 & 4 & . & 1 & . & 1 \\
\hline 16. Den haag & 680.391 & 4 & . & - & 1 & 1 \\
\hline 17. Delft & 247.657 & 1 & - & 1 & - & 1 \\
\hline 18. Midden-Holland & 219.921 & 2 & - & . & 2 & 2 \\
\hline 19. Rijnmond & 1.191 .080 & 12 & . & 1 & 5 & 6 \\
\hline 20. Dordrecht & 351.940 & 5 & - & 1 & 3 & 4 \\
\hline 21. Zeeland & 355.501 & $\epsilon$ & - & 1 & 4 & 5 \\
\hline 22. Breda & 601.836 & 8 & - & 2 & 4 & 6 \\
\hline 23. Tillburg & 376.468 & 3 & - & - & 3 & 3 \\
\hline 24. Den Bosch & 578.154 & 7 & - & 1 & 6 & 7 \\
\hline 25. Eindhoven & 642.345 & 6 & . & $i$ & 6 & 7 \\
\hline 26. Noord-Limburg & 440.610 & 3 & - & 1 & 2 & 3 \\
\hline 27. Zurd-Limburg & 631,464 & 6 & 1 & 1 & 5 & $6 @$ \\
\hline Totaal & 14.714 .948 & 154 & 3 & 25 & 87 & 115 \\
\hline
\end{tabular}

"Klinische revalidatie: "* Revalidatiedagbehandeling: ***Fysieke reconditionering: @1 instelling heeft zowel een ADB. als een firfor.ateling.

Het fysiotherapieprogramma duurde gemiddeld drie maanden, met een variatie tussen vijf en zestien weken. De klinische programma's namen een tijdspanne van ongeveer vier tot zes weken in beslag, de patiënten kregen dan doorgaans een dagvuliend programma: $29 \%$ van de patiënten kreeg hierna een poliklinische vervolgbehandeling. Het gemiddeld aantal fysiotherapiesessies lag op 26. Klinische afdelingen kwamen vanwege hun intensieve programma hoger uit, namelijk op 44 sessies. 


\section{Tabell IV}

Beschikbaarheid van disciplines per soort revalidatie afdeling na ontslagt

\begin{tabular}{|c|c|c|c|c|}
\hline & $\begin{array}{l}K \operatorname{Kin}^{*} \\
(\mathrm{~N}=3)\end{array}$ & $\begin{array}{l}\mathrm{RDE}^{*} \\
(N=25)\end{array}$ & $\begin{array}{l}F R^{* 2 *} \\
(\mathrm{~N}=83)\end{array}$ & $\begin{array}{l}\text { Totas } \\
(N=11)\end{array}$ \\
\hline \multicolumn{5}{|l|}{ Disciplines aamwezig } \\
\hline Cardioloog & 0 & $16(64 \%)$ & $35(42 \%)$ & $51(46 \%)$ \\
\hline Revalidatiearts & 1 & $12(48 \%)$ & $5(6 \%)$ & $18(16 \%)$ \\
\hline Internist/arts & 3 & $3(12 \%)$ & $11(13 \%)$ & $17(15 \%)$ \\
\hline Verpleegkundige & 2 & $9(27 \%)$ & $15(18 \%)$ & $26(23 \%)$ \\
\hline Fysiotherapeul & 3 & $25(100 \%)$ & $83(100 \%)$ & $111(100 \%)$ \\
\hline Dietiste & 2 & $8(32 \%)$ & $13(16 \%)$ & $23(21 \%)$ \\
\hline Maatschappellijk werker & 2 & $24(96 \%)$ & $26(31 \%)$ & $52(47 \%)$ \\
\hline Klinisch psycholoog & 2 & $11(44 \%)$ & $6(7 \%)$ & $19(17 \%)$ \\
\hline Secretaresse & 3 & $18(72 \%)$ & $18(22 \%)$ & $39(35 \%)$ \\
\hline Overige & \# & $8(32 \%)$ & $6(7 \%)$ & $15(14 \%)$ \\
\hline Gemiddeid & 6,3 & 5.4 & 2,6 & 3,3 \\
\hline \multicolumn{5}{|l|}{ Disciplines op atroep } \\
\hline Cardioloog & 3 & $9(36 \%)$ & $37(44 \%)$ & $49(44 \%)$ \\
\hline Revalidatiearts & 0 & $2(8 \%)$ & $10(12 \%)$ & $12(11 \%)$ \\
\hline Internist/arts & 0 & $3(12 \%)$ & $25(30 \%)$ & $28(24 \%)$ \\
\hline Verpleegkundige & 1 & $3(12 \%)$ & $20(24 \%)$ & $24(22 \%)$ \\
\hline Fysiatherapeut & 0 & 0 & 0 & 0 \\
\hline Dietiste & 1 & $10(40 \%)$ & $45(54 \%)$ & $56(50 \%)$ \\
\hline Maatschappelijk werker & 1 & $1(4 \%)$ & $40(48 \%)$ & $42(38 \%)$ \\
\hline Klinisch psycholoog & 1 & $10(40 \%)$ & $45(54 \%)$ & $56(50 \%)$ \\
\hline Secretaresse & 0 & $\|(4 \%)$ & $7(8 \%)$ & $8(7 \%)$ \\
\hline Overige & 0 & $3(12 \%)$ & $4(5 \%)$ & $7(6 \%)$ \\
\hline Gemiddeld & 2,3 & 1,7 & 2,8 & 2,5 \\
\hline
\end{tabular}

" Kinische revalidatie; "Revalidatiedagbehandaling; "*n Fysieke reconditionering; "op basis van enquêtegegevens.

Gemiddeld duurde een fysiotherapiesessie in alle drie de typen instellingen één uur (in $63 \%$ van alle afdelingen). Het betrof fysiotherapietraining in groepen. Sommige niet-erkende afdelingen (met weinig patiënten) gaven alleen individuele fysiotherapie van doorgaans een half uur (11\% van alle afdelingen). $17 \%$ van de afdelingen had sessies van langer dan één uur. De meest genoemde programmaonderdelen van de fysieke training waren: sport \& spel (92\% van alle afdelingen), fietsen $(89 \%)$, oefenzaal (74\%), ontspanningsoefeningen (62\%), circuittraining (50\%), loopband (21\%), zwemmen ( $15 \%)$ en wandelen (13\%). Dit geldt voor alle drie typen instellingen.

$68 \%$ van de patiënten rondde het volledige lysieke programma af, $19 \%$ volgde slechts een beperkt programma, terwijl 13\% voortijdig stopte. De belangrijkste redenen voor het voortijdig termineren wan het fysieke programma waren: cardiale klachten (19\%), andere fysieke klachten (16\%), overlijden (5\%) en weigering ( $4 \%$ ). 


\section{Testorocedures}

Zoals te verwachten was, werden testprocedures vaker uitgevoerd in erkende dan in niet-erkende afdelingen. In $17 \%$ van de afdelingen werd standaard geen inspanningstest gedaan woor de start van het oefenprogramma (tabel V). Van de afdelingen die dat wel deden, bood de helft een submaximale lest aan en de andere helft een maximale. Deeis vonden deze insparningstesten aan het einde van de opname plaats of vlak erna, ter screening van de highurisk patienten (zie voor frequentie testen hoofdstuk 3 ).

Een psychosociaal interview door een maatschappelijk werker werd vaker afgenomen in een erkende dan in een niet erkende afdeling. Psychologische vragenlijsten werden weinig gebruikt. Beide psychosociale instrumenten werden nog het meest toegepast in erkende afdelingen verbonden aan een revalidatiecentrum (tabel V).

\section{Tabel V}

Soorten testprocedures die standaard per type afdeling bij aanwang en/of afsluiting van rovalidatie na ontslag uitgevoerd worden

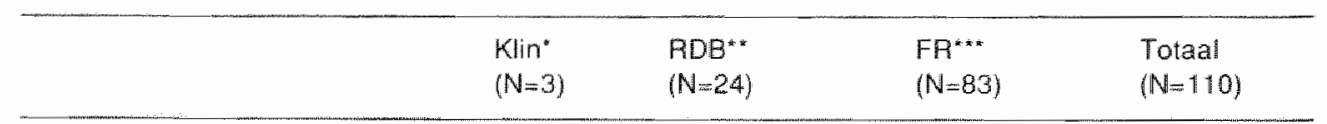

Testorocedures bij aanvang

\section{Cardiaal onderzoek}

Submaximale inspanningstest

Maximale inspanningstest

Psychosociaal interview

Psychologische vragentijst

(2)

$\begin{array}{ll}2 & 20(83 \%) \\ - & 11(46 \%) \\ 1 & 12(50 \%) \\ 2 & 14(58 \%) \\ 1 & 5(21 \%)\end{array}$

\section{Bij afsluting}

Cardiaal onderzoek

Submaximale inspanningstest

Maximale inspanningstest

Psychosocial interview

Psychologische vragenlijst

$\begin{array}{rcc}20(83 \%) & 49(59 \%) & 71(64 \%) \\ 11(46 \%) & 35(42 \%) & 46(41 \%) \\ 12(50 \%) & 34(41 \%) & 47(42 \%) \\ 14(58 \%) & 6(7 \%) & 22(20 \%) \\ 5(21 \%) & 3(4 \%) & 9(8 \%)\end{array}$

"Klinische revalidatio; " Revalidatiedagbehandeling: "Fysieke recondilionering; op basis van enquetegegevens.

\section{Groepsvoorlichting}

Systematische voorlichting vond meestal groepsgewijs plaats. Uiteraard werd ook voorlichting op ad hoc basis gegeven tijdens individuele gesprekken met artsen gedurende de opname en op de polikliniek of met de maatschappelijk werker of andere disciplines. Deze individuele voorlichting wardt hier niet besproken.

De groepsprogramma's variëerden in hoge mate betreffende doelstellingen, aantal sessies, organisatievorm en betrokken disciplines. Het aantal voorlichtingssessies variëerde van één tot tien. Soms was er een groepsprogramma specitiek gericht op 


\section{Tabel VI}

Psychosociale zorg en dietetiek tijdens revalidatie na ontslag per soort afdeling $(N=1499)$

\begin{tabular}{lrrr}
\hline Programma onderdeel & Klin & RDB** & FR*** \\
\hline Psychosociaal groepsprogramma & $52 \%$ & $7 \%$ & $9 \%$ \\
Consult maatschappelijk werk & $33 \%$ & $15 \%$ & $13 \%$ \\
Consult klinisch psycholong & $9 \%$ & $3 \%$ & $13 \%$ \\
Consult diëtist & $32 \%$ & $7 \%$ & $9 \%$ \\
Groepswoorlichting diëtist & $57 \%$ & $62 \%$ & $24 \%$ \\
\hline
\end{tabular}

"Klinische revalidatie; "* Revalidatiedagbehandeling: "** Fysieke reconditionering: \# op basis van patiëntenregistratiegegewens)

partners. De meest betrokken disciplines bij de groepsvoorlichting waren: maatschappelijk werker, diëtiste, fysiatherapeut, klinisch psycholoog en cardialoog.

49 instellingen ( $42 \%$ ) boden een of andere vorm van groepswoorlichting aan: 2 van de 3 centra voor klinische revalidatie, 6 van de 7 revalidatiecentra met revalidatiedagbehandeling, 9 van de 18 algemene ziekenhuizen mel revalidatiedagbehandeling en 32 van de 87 niet-erkende afdelingen. Ook in dit opzicht kan ruim eenderde van de niel-erkende afdellingen zich meten met de erkende! Over de kwaliteit van dengelijke bijeenkomsten kan via dit onderzoek geen uitspraak gedaan worden.

$52 \%$ van de patiënten die klinische revalidatie hadden, kreeg een groepsprogramma. Bij de andere instellingen gold dit slechts voor $8 \%$ van de patiënten (tabel VI), waarbij opviel dat in afdelingen voor revalidatiedagbehandeling verbonden aan algemene ziekenhuizen een dergelijk programma aan weinig patiënten ( $9 \%$ ) werd aangeboden.

\section{Individuele psychosociale zorg}

Onder individuele psychosociale zorg wordt hier de hulpverlening verstaan die gegeven wordt door maatschappelijk werker en klinisch psycholoog (ot soms psychiater). Een maatschappelijk werker was bij $52 \%$ van de aidelingen aanwezig en in $42 \%$ van de gevallen op afroep beschikbaar. Een klinisch psycholoog was slechts bij $19 \%$ van de afdelingen aanwezig en bij $56 \%$ op consultbasis te raadplegen (tabell IV).

$10 \%$ van alle patiënten kreeg individuele behandeling door de klinisch psycholoog en $17 \%$ door de maalschappelijk werker (tabel VI). Ook hier bestond weer een grote spreiding per afdeling: betreffende de klinisch psycholoog was er een variatie van 1 tot $75 \%$ en de maatschappelijk werker van 1 tot $100 \%$

\section{Dietetiek}

Bij 21\% van de instellingen maakte een diëtiste deel uit van hel team. Ze deed aan groepsvoorlichting betreffende gezonde woeding en gat individuele consulten. Hoewel bij de helft van de instellingen, met name de niet-erkende, de diëtiste slechts op atroep 
ler beschikking stond, was zij bij 16\% wan de niel-erkende instellingen in het team aanwezig (tabel IV).

Bij instellingen die een diëtiste ter beschikking hadden, kwam $43 \%$ van alle patiënten daadwerkelijk in contact met haar middels een groepswoorlichtingsgesprek (variatie $0 \%$ - $100 \%$ per afdeling). Daamaast kreeg $15 \%$ individuele diẽetadviezen en begeleiding (variatie $0 \%-46 \%$ ) (tabel VI). Opvallend is thet lage aantal individuele consulten bij de afdelingen voor revalidatiedagbehandeling $(7 \%)$, dat in dezelide orde van grootte blijkt te liggen als voor niet-erkende atdelingen.

\section{Deelname partner}

Slechts bij ongeveer eenderde van alle afdelingen kon ook de partner actief deelnemen aan het hele fysieke programma of een deel ervan. Bij erkende afdelingen was daar meer mogelijkheid toe dan bij niet-erkende. Deelname aan het psychosociale programma was wel vanzelfsprekend: doorgaans werden de partners bij alle voorlichtings- en gespreksgroepen uitgenodigd. Enkele instellingen gaven gespreksgroepen apart voor partners! 11\% van de partners (variërend van 1 tot $65 \%$ per afdeling) deed mee met een deel van of het hele fysieke programma. $69 \%$ van de deelnemers aan een psychosociaal groepsprogramma werd vergezeld door hun partner.

\section{Beleid na afloop van de revalidatie}

De patiënten kregen aan het einde van de rewalidatie bijna allemaal het advies om fysieke activiteiten te ontplooien, met name door deel te nemen aan een sportgroep of door te gaan fietsien, wandelen of zwemmen.

Uiteraard kregen alle patiënten poliklinische cardiologische zorg na afloop van de revalidatie en bijna alle patiënten werden terugverwezen naar de huisarts ter verdere begeleiding, 3\% werd doorverwezen voor verdere psychosociale zorg (algemeen maatschappelijk werk, RIAGG, klinisch psycholoog, psychiater).

\section{Patiëntgegevens}

\section{Aantal gerevalideerde patiènten}

De drie klinische afdelingen tezamen behandelden per jaar naar schatting ongeveer 750 patiënten. De dagbehandelingsafdelingen van revalidatiecentra behandelden eveneens gemiddeld 250 patiënten per jaar, die van algemene ziekenhuizen ongeveer 160 , de niet-erkende afdelingen ongeveer 95 patienten. Op grond van deze cilfers worden per jaar in Nederland naar schatting in totaal ongeveer $\$ 3.500$ patiënten gerevalideerd na ontslag uit het ziekenhuis, waarvan ca. 8.250 patiënten in niet-erkende afdelingen en 4.500 patienten in erkende afdelingen.

\section{Geslacht}

De deelname van vrouwen aan hartrevalidatie nam van slechts $13 \%$ in 1985 toe thot $26 \%$ in 1988 (tabel VII). Met name de klinische revalidatieafdelingen revalideerden het hoogste percentage vrouwen (tabel VIII). Dit hangt samen met de gemiddelde leeftijd van de patiënten. 


\section{Leeftijd}

Door de jaren heen werden steeds meer oudere patienten (boven de 70 jaar) gerevallideerd: in 1985 nog $5 \%$, in 1988 al $17 \%$ (tabel Vil). Met name de kimische afdelingen revalideren juist veel meer patiënten boven de 70 jaar.

\section{Tabel VII}

Indicatie-, geslacht- en leettijdsverdeling van patiënten met revalidatie na ontslag per soort afdeling\#

\begin{tabular}{llllll}
\hline NN=1898) & & Klin $^{*}$ & RDB $^{* *}$ & FR** & Totaal \\
\hline Indicatie: & Infarct & $36 \%$ & $50 \%$ & $64 \%$ & $51 \%$ \\
& Operatie & $45 \%$ & $39 \%$ & $27 \%$ & $36 \%$ \\
& Rest & $19 \%$ & $11 \%$ & $9 \%$ & $13 \%$ \\
Geslacht: & Man & $61 \%$ & $83 \%$ & $81 \%$ & $74 \%$ \\
& Vrouw & $39 \%$ & $17 \%$ & $19 \%$ & $26 \%$ \\
& & & & & $19 \%$ \\
Leeftijd: & 50 jaar & $16 \%$ & $20 \%$ & $22 \%$ & $64 \%$ \\
& $50-70$ jaar & $54 \%$ & $71 \%$ & $68 \%$ & $17 \%$ \\
& $\geq 70$ jaar & $30 \%$ & $9 \%$ & $10 \%$ & \\
\hline
\end{tabular}

* Klinische revalidatie; ** Revalidatiedagbehandeling; ${ }^{* * *}$ Fysieke reconditionering; \# op basis van patiëntenregistratiegegevens.

\section{Indicaties}

$51 \%$ van de patiënten werd gerevalideerd na een hartinfarct, $36 \%$ na een hartoperatie en $13 \%$ ma een andere indicatie (angina pectoris, percutane transluminale coronairangioplastie, hartfalen) (tabel Vlli). Deze verhoudingen bleven in de loop van het onderzoek vrij constant. De klinische afdelingen revalideerden in vergelijking met de andere afdelingen veel meer operatiepatiënten en ook meer patiënten uit de categorie "rest",

Door alle afdelingen werden palienten gerevalideerd uit de categorie "rest": dreigend infarct, AP, pompfunctiestoormis of PTCA (ca. 13\% van het totaal). In welke verhouding dit slaat tot het totaal aantal opnames met deze diagnosen is onbekend. Over de aanpak van deze groepen is ook onvoldoende bekend.

\section{Verwijzingen}

Twee zlekenhuizen die deelnamen aan de gegevensverzameling door middel van de individuele patiëntenlijst gaven geen revalidatie na onislag. Van hun patiènten werd $39 \%$ naar een revalidatiecentrum verwezen, bij $61 \%$ was er geen vervolgbehandeling. Ruim de helft van alle patiënten die tijdens de opname gerevalideerd waren in een ziekenhuis met een eigen mogelijkheid voor revalidatie na ontslag, kregen deze nazorg niet, $31 \%$ kreeg na ontslag revalidatie in het eigen ziekenhuis, terwijl $13 \%$ in een andere instelling nabehandeld werd. Opwallend was dat met name bij veel infarctpatiènten ( $56 \%$ ) en patiënten uit de restcategorie $(87 \%)$ de revalidatie tijdens opname geen vervolg kreeg (tabel Vill). 


\section{Tabell Vill}

Aantal patienten per diagnose dat tijdens opname gerevalideerd is en een vorm van revalidatie na ontslag kreeg ${ }^{3 t}$

\begin{tabular}{|c|c|c|c|c|c|c|c|c|}
\hline \multirow[b]{2}{*}{ Eigen ziekenhuis } & \multicolumn{2}{|c|}{ infarctpatientien } & \multicolumn{2}{|c|}{ Operatiepatientien } & \multicolumn{2}{|c|}{ Restcategorie } & \multicolumn{2}{|l|}{ Totaal } \\
\hline & 648 & $(36 \%)$ & 319 & $(42 \%)$ & 100 & $(12 \%)$ & 1.067 & $(31 \%)$ \\
\hline Ander ziekenhuis & 14 & $(1 \%)$ & 288 & $(38 \%)$ & 3 & $(0 \%)$ & 305 & $19 \%)$ \\
\hline Revalidatiecentrum & 78 & $(4 \%)$ & 88 & $(12 \%)$ & 2 & $(2 \%)$ & 168 & $(5 \%)$ \\
\hline Fysiotherapie in periferie & 29 & $(2 \%)$ & 5 & $(1 \%)$ & 1 & $(0 \%)$ & 35 & $(1 \%)$ \\
\hline Geen woortzetting & $1.021^{*}$ & $(56 \%)$ & $54^{2 * *}$ & $(7 \%)$ & $744^{* * *}$ & $(87 \%)$ & 1.819 & $(53 \%)$ \\
\hline Anders & 15 & $(1 \%)$ & 2 & $(0 \%)$ & 4 & $(1 \%)$ & 21 & $(1 \%)$ \\
\hline Totaal & 1.805 & $(100 \%)$ & 756 & $(100 \%)$ & 854 & $(100 \%)$ & 3.415 & $(100 \%)$ \\
\hline
\end{tabular}

"spreiding 6\%-79\%," spreiding $0 \%-69 \%$; "*" spreiding $0 \%-97 \%$; \# op basis van paliêntenregistratiegegevens.

Er was een enorme variatie per ziekenhuis (mel eigen mogelijkheid voor revalidatie na ontslag) in het percentage infarctpatiënten dat geen revalidatie na ontslag kreeg: van $6 \%$ tot $79 \%$ ! Daarentegen kreeg de revalidatie van slechts $7 \%$ van alle operatiepatienten geen vervolg (tabel VIII). Operatiepatiënten werden overigens veelvuldig in andere instellingen gerevalideerd ( $51 \%$ ), wat ondermeer verklaard kan worden door het feit dat de start van de revalidatie in het operatieziekenhuis plaatsvond. Na de operatie werden veel patiënten weer teruggestuurd naar het ziekenhuis waar ze oorspronkelijk opgenomen waren, alwaar ze verder gerevalideerd werden. Patiënten met complexe problematiek werden echter doorgestuurd naar een klinisch revalidatiecentrum.

Patiënten van revalidatiedagbehandelingsafdelingen (verbonden aan algemene ziekenhuizen) en van de niet-erkende afdelingen waren bijna allemaal afkomstig uit het eigen ziekenhuis; sporadisch werd iemand via de huisarts of via een ander ziekentuis doorverwezen. Er bestond dus nauwelijks een supraregionale functie zoals verwacht zou mogen worden voor de afdelingen met erkenning. De patiënten die in een revalidatiecentrum gerevalideerd werden, kwamen viteraard uit andere instellingen. De drie afdelingen voor kinische rewalidatie hadden wel een supraregionale functie, zij het dat ze samen niet het hele land bestreken en dat een groot deel van hun patienten wit de eigen verzorgingsregio afkomstig was.

Uit onze steekproef door middel van de individuele patiëntenlijsten in 15 ziekenhuizen bleek dat $46 \%$ van alle tijdens de opname gerevalideerde patiënten doorgestuurd werd voor een of andere vorm van revalidatie na ontslag: $43 \%$ van de infarctpatiënten, $93 \%$ van de operatiepatienten en $12 \%$ van de restcategorie. 


\subsection{DISCUSSIE}

Deze studie biedi een vrijwel compleet en daardoor betrouwbaar beeld van de stand van zaken van de hartrevalidatie na ontslag uit het ziekenhuis. Het is tevens een unieke studie: nergens ter wereld is een zo omvangrijk onderzoek gedaan. Op deze schaal zijn patiëntkenmerken elders evenmin beschikbaar.

\subsubsection{Onderzoekspopulaties}

In de patiëntenpopulatie van de individuele patiëntenregistratielijsten zit een bias, omdat relatief veel klinische revalidatiepatiënten er deel van uitmaakten. Deze patiënten waren ouder, een groter deel was vrouw, bovendien zaten in deze onderzoeksgroep meer operatiepatiènten en meer patiënten uit de restgroep dan in de tolale revalidatiepopulatie. De populatie omvatte $13 \%$ van alle revalidatiepatiënten ( $11 \%$ van alle infarct-en $15 \%$ van alle operatiepatiënten). Alle klinische revalidatieafdelingen, $8 \%$ van de erkende en $12 \%$ van de niet-erkende afdelingen waren vertegenwoordigd. Erkende afdelingen verbonden aan een revalidatiecentrum deden niet mee. De onderzoeksgroep kan daarom niet geheel representatief geacht worden als het gaat om diagnosegroepen en typen instellingen.

Met behulp van de enquêtes werden nagenoeg alle instellingen bereikt, waardoor een redelijk compleet beeld van de instellingen en hun programma-onderdelen geschetst kon worden.

\subsubsection{Dataverzameling en beperkingen}

De patiëntenaantallen verkregen via deze enquêtes zijn minder compleet: vaak ontbraken bij de gegevens van de responderende afdelingen cijfers hieromtrent. Vrijwel altijd waren de ciffers retrospectief.

De data die met behulp van de enquêtes verzameld zijn, betreffen in feite alleen die patiënten die een fysiek programma doorlopen hebben. Onduidelijk is dan ook hoeveel patiënten gebruik hebben gemaakt van andere revalidatieonderdelen, zoals een psychosociaal groepsprogramma of consulten van diëtiste, maatschappelijk werker of klinisch psycholoog. Daarnaast is onduidelijk of er ook patiënten zijn geweest die van andere faciliteiten gebruik maken zonder deel te nemen aan het fysieke programma.

Mogelijk zijn de medische en fysieke kanten van de hartrevalidatie better belicht dan de psychosociale, omdat de data aangeleverd zijn door fysiotherapeuten.

\subsubsection{Vergelijking van de onderzoeksmethoden}

Doordat met beide onderzoeksinstrumenten, enquête en patiëntenregistratielijst, ten aanzien van een aantal dezelfde variabelen bij dezelfde afdelingen gegevens verzameld 
zijn, biedt dil de mogelikheid de gevonden data met elkaar te vergelijken. De variabelen die hiervoor in aanmerking komen zin: "start fysiotherapie na ontslag uit het ziekenthuis", "duur van hel fysieke programma", "aantal sessies fysiotherapie", "aantal patienten voortijdig gestopt", "aantal gerevalideerde patienten", "geslachtsverdeling", "leeftijosverdeling", "indicatie".

De scores op de variabelen "aantal gerevalideerde patiënten", "aantal weken dat fysiotherapie start na ontslag", "percentage patienten dat voortijdig stopt mel fysiotherapie", "leeftijdsverdeling van de gerevalideerde patienten", "aantal sessies fysiotherapie" laten enige atwikking zien tussen de beide onderzoeksmethoden. Hierbij geven de data van de enquête een gunstiger beeld (zie tabel $1 \mathrm{X}$ ). De scores op de variabelen "duur van het fysiotherapie programma", "indicatie van gerevalideerde patienten", "geslachtswerdeling van gerevalideerde patienten" komen in hoge mate met elkaar overeen.

Concluderend kan gesteld worden dat de data varn beide onderzoeksinstrumenten redelik met elkaar overeenstemmen.

\section{TabelIX}

Vergelijking van data omtrent de fase na ontslag uit het ziekenthuis verkregen met behulp van enquêtes en individuele patiëntenregistratielijst (IP)

\begin{tabular}{|c|c|c|c|}
\hline Variabelen & & Enquetes & $\mathbb{P}$ \\
\hline Aantal gerevalideerde patiennten per afdeling & & 124 & 114 \\
\hline \multirow[t]{2}{*}{ Aantal weken dal fysiotherapie stant na ontslag uit ziekenhuis } & infarct & 2,5 & 3,0 \\
\hline & operatie & 2,5 & 3,5 \\
\hline Percentage patienten vooriijdig gestopt met fysiotherapie & & $10,5 \%$ & $16 \%$ \\
\hline Duur fysiotherapie programma in weken & & 11 & 11 \\
\hline \multirow[t]{3}{*}{ Indicatie gerevalideorde patienten } & inferet & $69 \%$ & $68 \%$ \\
\hline & operalie & $22 \%$ & $23 \%$ \\
\hline & rest & $9 \%$ & $9 \%$ \\
\hline \multirow[t]{2}{*}{ Geslacht gerevaliclearde patienten } & Man & $82 \%$ & $80 \%$ \\
\hline & Vrouw & $18 \%$ & $20 \%$ \\
\hline \multirow[t]{3}{*}{ Leefifid gerevalideerde patiënten in jaren } & $0-50$ & $31 \%$ & $21 \%$ \\
\hline & $50-70$ & $56 \%$ & $63 \%$ \\
\hline & $70-$ & $13 \%$ & $16 \%$ \\
\hline Aantal sessies fysiotherapie & & 28 & 23 \\
\hline
\end{tabular}




\subsubsection{Beschouwingen}

In het navolgende worden de in dit onderzoek gevonden gegevens vergeleken met ciffers uit andere bronnen uit binnen- en buitenland. Buiten Nederland zijn data beschikbaar uit de volgende landen: Engeland, Italië, Australië, Verenigde Staten en Canada. Verder zullen de gevonden resultaten getoetst worden aan de doelstellingen van revalidatie.

Vanaf 1970 heeft er een enorme groei van het aantal revalidatie-afdelingen plaatsgevonden: van 5 in 1970, 46 in 1979 tot 115 in 1989 (Weeda \& Visser, 1981: Meegdes. 1988 ). $23 \%$ van de algemene en academische ziekenhuizen had in 1988 geen eigen afdeling voor revalidatie na ontslag. Dit komt overeen met de bevindingen van de NVFH (NVFH, 1988) dat een percentage van $20 \%$ vond. Overigens verwijst het merendeel van deze ziekenhuizen wel door naar een erkend centrum.

In hel buitenland is revalidatie veel minder mogelijk: in Engeland in $42 \%$ van de ziekenhuizen (Green ea, 1988) en in Australië in 17\% (Worcester, 1986). Gesteld kan worden dat Nederland in vergelijking met het buitenland ruim voorzien is van revallidatiemogelijkheden.

Bij de afdelingen met een erkenning woor revalidatiedagbehandeling is een duidelijke tweedeling zichtbaar. Aan de ene kant bevinden zich de afdelingen die verbonden zijn aan revalidatiecentra: deze hebben conform de tinancieringsregeling (Ziekenfondsraad, 1981) een uitgebreide multidisciplinaire staf en een breed pakket aan behandelmogelijkheden; bovendien vervullen ze in redelijke mate hun regionale functie. Deze instellingen voldoen in hoge mate aan de eisen voor regionale, gespecialiseerde afdelingen voor hartrevalidatie zoals die in 1966 opgesteld zijn door de Revalidatie Commissie (NHS , 1966). Aan de andere kant zijn er de afdelingen voor revalidatiedagbehandeling die verbonden zijn aan algemene ziekenhuizen: deze hebben een minder uitgebreide staf en een beperkter behandelingspakket, terwijl ze niet of nauwelijks een regionale functie vervullen; ze voldoen dan ook niet of slechts in beperkte mate aan het besluit revalidatie dagbehandeling (Ziekenfondsraad, 1981 en 1989). Het rapport van de Revalidatie Commissie uit 1977 (NHS, 1977) geeft aan dat er geen unanimiteit bestond betreffende de organisatie van de hartrevalidatie in Nederland: een deel van de commissie hield vast aan de bovengenoemde specialistische en regionaal opererende revalidatieafdelingen. terwijl een ander deel de voorkeur eraan gaf dat mel name de grote ziekenhuizen zelf hun hartrevalidatie organiseerden. Dit verschil in opvatting heeft zich vertaald naar de praktijk, waarin momenteel deze twee typen afdelingen naast elkaar bestaan!

De amvang van de klinische revalidatie is vanat de start in 1970 door de jaren heen ongeveer hetzelíde gebleven. Hoewel de instellingen die klinische revalidatie geven niet alleen patiënten opnemen uit de eigen verzorgingsregio, is het gebruik van hun facillteiten toch niet evenredig over Nederland verspreid, maar beperkt tot die gebieden waar ze gevestigd zijn. Vooral naburige ziekenhuizen verwijzen patiënten naar deze centra door.

Deze klinische centra revalideren een andere populatie dan de overige instellingen: meer operatiepatiënten, meer probleemgevallen, meer ouderen en ook meer vrouwen. Bowendien is er ruim magelijkheid het behandelprogramma toe te spitsen op de individuele 
patient. In een onderzoek van Bär ea (1988) gericht op de situatie van het Revalidatie Centrum Hoensbroek word bevestigd dat de behandelde populatie patienten fors afwilkt wan die van polikimische atdelingen.

Overigens verlopen de verwijzingen naar de verschillende lypen afdelingen lang niet altiid adequal. Er is lanclijk gezien geen adequate selectie en indicatiestelling voor revalidatie na ontslag

Internationdal gezien bestaat er een grole variatie in de verhouding poliklinische en kinische revalidatie. Zoals al eerder gesteld, is er hierover echter slechts weinig literaluur bekend. Duitsland (Jetle ea, 1988, pelijaar 1988) kent vijwel alleen maar klinische revalidatie in speciale klinieken, waarvam er 196 zijn. De gemiddelde behandelduur aldaar is ongeveer vier weken. In CanadaJ Ontario en in de VSNirginia (Wolfe ea, 1990; Wolte ea, 1987; pelljaar 1983 en 1985), alsmede in Australiè (Worcester, 1986; peiljaar 1985 ) wordt uitsluitend poliklinische revalidatie gegeven. Italie (Giondano, 1989; peiljaar 1987) neemt een tussenpositie in: 9 van de 59 instellingen bieden kinische revalidatie aan, 16 kinische en poliklinische revalidatie en de rest alleen poliklinische revalidatie. Samenvattend kan gesteld wonden dat Nederland, in vergelijking met het builenland, een gedifferentieerd aanbod van instellingen voor hartrevalidatie na ontslag uit het ziekenhuis heeft.

Het percentage verpleegkundigen nam door de jaren heen af $168 \%$ in 1979 , tegen $45 \%$ in 1988) (Weeda \& Visser, 1981; Dixhoorn van ea, 1988). Dit betekent dat revalidatie na ontslag uit het ziekenhuis organisatorisch losser is komen te staan van de verpleegafdeling. Gezien de thancieringsiegeling zouden bij niet-erkende aldelingen alleen een arts (op airoep) en een fysiotherapeut (aanwezig) te verwachten zijn. De cijfers laten echter zien dat ongeveer een derde van deze afdelingen werkte met een team dat vergelijkbaar was met dat van een erkende afdeling.

In het buttenland zijn de fysiotherapeuten, evenals in Nederland, vrijwel altijd bij de revalidatie betrokken (Wolfe ea, 1990; Worcester, 1986; Giordano, 1989; Soons \& Bär, 1990a; Green ea, 1988). De overige disciplines zijn in het butenland juist veel minder vertegenwoordigd: diëtiste (Nederland 71\%; Engeland 50\%; Italie 31\%; Canada/Ontario $25 \%$, Australie $68 \%$ ), maatschappelik werker (Nederland $94 \%$, Engeland 24\%; Australie $17 \%$, VS 16\%), kimisch psycholoog (Nederland $75 \%$; Engeland $26 \%$; Italie $42 \%$; CanadaVntario $7 \%$; Australië zelden; VS 22\%). Gesteld kan worden dat in Nederland veel vaker multidisciplinair gewerkt wordt dan in het buitenland.

In 1979 werd door tweederde van de instellingen een leeftijdsgrens in verband met mogelijke werkherwatting als insluiting voor revalidatie gehanteerd (Weeda \& Visser: 1981), anno 1989 door nog slechts enkele ziekenhuizen, hetgeen betekent dat de doelstelling van werkhervatting als algemeen doell is losgelaten. Dit neemt natuurlik niet weg dat werkhervatting nog steeds een individuele doelstelling kan zijn.

Uit de onderzoeksgegewens blijkt dat polikinisch vrijwel alleen standaard groepsfysiotherapieprogramma's gegeven worden. Op deze wijze wordt onvoldoende tegemoel gekomen aan de individuele noden van de patient (Soons \& Bär, 1990). De mogelijkheid 
tol individuele aanpassing van het programma dient aanwezig te zijn. Dit geld niet aleen voor de niet-erkende, maar ook voor alle afdelingen met revalidatiedagbehandeling, die oorspronkelijk opgezet waren om complexere patienten ook op individuele basis te revalideren. In de klinische centra is er wel uigebreid de mogelijkheid voor individuele fysiotherapie.

Na ontslag uit het ziekenhuis wordt steeds sneller met fysieke training gestart: in 1979 begon slechts $26 \%$ wan de instellingen binnen wee weken, in 1984 reeds $64 \%$ en in $198871 \%$ (Dixhoorn van ea, 1988; Weeda \& Visser, 1981; Aquarius \& Smit, 1980). Deze trend ligt in hel werlengde van de opvatting dat patienten na een hartinfarct of hartoperatie weer zo snel mogelijk gemobiliseerd en geactiveerd moeten worden, en dat dit veilig kan gebeuren (Mallory e.a., 1939; Harrison, 1944; Editorial, 1974; Wenger, 1977; West \& Henderson, 1979; Messen \& Demaret, 1982; Wenger ea, 1982; Wenger, 1982; Collins ea, 1984; Wenger, 1984; Bär ea, 1988). De kans op terugkeer in het arbeidsproces wordt overigens niet groter (Diederiks, 1982; Wiklund e.a., 1985). Van twee landen buiten Nederland is het moment van starten bekend: in Engeland start de meerderheid van de instellingen binnen vier weken (Green ea, 1988), in Australië, evenals in Nederland, binnen twee weken (Worcester, 1986).

Er bestaal een redelijke consensus betreffende duur en intensiteit van fysieke revalidatie in Nederland: de gemiddelde duur is 12 weken met een gemiddelde van 26 sessies. Het blikt dat steeds meer afdelingen naar deze gemiddelden opschuiven. In 1979 lag de gemiddelde revalidatieduur nog op 16 weken en hel aantal sessies gemiddeld op 33; er was ook een grotere variatie (Weeda \& Visser, 1981; Aquarius \& Smit, 1980). Mogelijk wordt het belang van langdurige intensieve training de laatste jaren lager ingeschat en realiseert men zich dat conditieverbetering slechts als hulpmiddel moet worden gezien bij het herstel van de patiënt. Ook kunnen de bezuinigingen meespelen. Gemiddeld twee keer per week oefenen is overigens onvoldoende om een maximaal tysiek trainingseffect te bereiken (Dixhoorn van ea, 1988). Verder zijn mogelijk de programma s in het ziekenhuis korter geworden omdat in veel regio's de fysieke training vervolgd kan worden door deelname aan sportgroepen voor hartpatienten (onderhoudstase)

Buiten Nederland is van twee landen de gemiddelde duur van het fysieke programma bekend: Engeland 6-8 weken (Green ea, 1988) en Australië eveneens 6-8 weken (Worcester, 1988). Betreffende het aantal fysiotherapiesessies ziln uit het buitenland geen cijfers bekend.

Duidelijk is dat fysiotherapie een in elk revalidatie programma aanwezig onderdeel is. Een belangrike reden hiervoor is dat el een expliciete financieringsregeling is gekomen voor dit onderdeel. Bovendien vormen fysiotherapeuten een beroepsgroep die met grote inzet en voortwarendheid hum aanpak van hartpatienten hebben geprofessionaliseerd. Zo bestaat er al jarenlang een eigen revalidatiecursus, mede onder auspicien van de Nederlandse Hartstichting. Verder appelleert fysieke training sterk aan de patient: er moet hard gewerkt worden om beter te worden. Niel vergeten dient te worden dat het beginnen met fysiotherapie ingegeven werd door de deconditionering vanwege een te lange bedrust. Aangezien het deconditioneringseffect aanzienlijk verminderd is door 
verkorting van de opnameperiode valt deze reden voor het uitvoeren van fysieke training deels weg. Overigens kan angst voor inspanning een belangrijke beperkende factor zijn in het herstel en kan tysieke training een goede methode zijn om dit te doorbreken. Het is echter niet de enige methode en ook niet altijd de beste. Belastbaarheid verhogen en conditie verbeteren is echter hooguit een intermediair doel. Van belang is het dan ook zich bijelke patient af te vragen of conditieverlies is opgetreden en of fysieke verbetering bijdraagl aan herstel in ruimere zin.

De inspanningstest is bedoeld om "high-risk"-patiènten op te sporen (WHO, 1972; Waters, $1986 a$ en b; Waters ea, 1985) en om de belastbaarheid te meten. Onderzoek heeft aangetoond dat een inspanningstest kort na een infarct veilig kan worden uitgevoerd (Blomqvist, 1971; Froelicher ea, 1979; Lindvall ea, 1979; Theroux ea, 1979; Davidson \& DeBusk, 1980; Vermeulen, 1983; Pryor ea, 1983; Weiner, 1986a en b). Een maximale inspanningstest brengt nauwelijks meer risico's met zich mee dan een submaximale, terwijl de diagnostische waarde van een maximale test aanzienlijk hoger is (Miller \& Borer, 1982).

In Australië (Worcester, 1986) kon in $198527 \%$ van de ziekenhuizen een poliklinische inspanningstest uitwoeren. In Engeland (Green ea, 1988) had $37 \%$ van de instellingen die een poliklinisch fysiek programma boden, in 1985 de mogelijkheid voor een inspanningstest. Uit onderhavig onderzoek blijkt dat hoewel in Nederland de meeste afdelingen een inspanningstest kunnen afnemen, er een grote variatie is in het percentage patienten dat zo'n test daardwerkelijk krijgt. In de praktijk bestaat er kennelijk geen duidelijkheid over de vraag welke patiënten, wanneer en op welke gronden zo'n test behoeven. In hoeverre de gegevens van de test in de praktijk verder nog gebruikt worden is ter discussie. Immers de patiënten krijgen een standaard groepsprogramma, waarbij de test hooguit als ingangscriterium van veiligheid wordt gebruikt. Harde bewijzen dat dit zinvol is zijn er overigens niet.

Psychologische vragenlijsten worden erg weinig gebruikt. Deze kunnen een belangrijke signalerende, evaluerende en selecterende functie hebben, die een aanvulling geeft op de "klinische blik". In Nederland is de meest gebruikte de Medisch Psychologische Vragenlijst voor Hartpatiënten (Erdman, 1982), die het welbevinden wan de patiënt meet. Daamaast bestaan er diverse andere vragenliisten die gebruikt kunnen worden om onder andere angst, depressie en type-A gedrag te meten (Soons, 1989; Soons \& Erdman, 1990). Echter er is geen overeenstemming over welk instrument het best gebruikt kan worden. Gesteld kan dan ook worden dat er zowel op fysiek als op psychosociaal vlak niet consequent geèvalueerd wordt.

Ongeveer een kwart van de afdelingen had een groepsvoorlichtingsprogramma, hetgeen overeenkomt met de resultaten van Maes ea (1986). Het nut hiervan is aangegeven door Maes en van Elderen (Maes ea, 1987; Elderen van \& Maes, 1988; Maes \& Elderen van, 1988). mits ze volgens een bepaald stramien zijn opgezet. Buiten Nederland zijn hierover alleen van Australië cijfers bekend: $24 \%$ van de ziekenhuizen die hartpatiënten opnamen. had een poliklinisch voorlichtingsgroepsprogramma (Worcester, 1986). 
In Nederland vertoont het beschikbaar zijn van de psychosociale disciplines een duidelijke toename. Door de Jaren heen is het percentage instellingen dat aan psychosociale zorg doet, toegenomen: het beschikbaar zijn van een maatschappeijk werker steeg van $67 \%$ in 1979 tot $85 \%$ in 1988 en van een kinisch psycholoog van $46 \%$ in 1979 tot $67 \%$ in 1988 (Weeda \& Visser, 1981; Dixhoorn van ea, 1988). Dit wijst op meer aandacht voor en acceptatie van psychosociale aspecten bij de revalidatie. Tegelikentijd bestaat er een grote variatie in het percentage patiënten per afdeling dat deze individuele consulten daadwerkelijk krijgt, wat overeenkomt met de situatie in de Zuid-Limburgse ziekenhuizen (Gosselink, 1989).

Buiten Nederland is de beschikbaarheid van de genoemde disciplines veel geringer Worcester, 1986; Wolte ea, 1987; Green ea, 1988; Giordano, 1989; Southard \& Broyden, 1990; Wolfe ea, 1990).

In dit onderzoek is uitgegaan van een onderscheid tussen psychosociale zorg in engere zin en die in ruime zin. Psychosociale zorg in engere zin beperkt zich tot de zorg door kinisch psycholoog en maatschappelijk werker. Dat neemt niet weg dat de imbreng van andere disciplines ook psychosociaal gericht kan zijn, of dat deze een belangrijke rol kunnen spelen in de psychosociale zorg, zoals bijvoorbeeld het geruststellen van patienten of het fungeren als gespreksleider van een voorlichtingsbijeenkomst.

Het percentage instellingen met een te consulteren diëtiste is gegroeid van $24 \%$ in 1979 tot $71 \%$ in 1988 , hetgeen wijst op een toegenomen interesse voor gezonde eetgewoonten. Ook hier bestaat een grote variëteit in het percentage patiënten per afdeling dat groepsvoorlichting of een individueel consult krijgt.

Hoewel de partners veelal hun eigen problematiek hebben, zijn zij toch zeer belangrijk bij de revalidatie van hartpatiënten (Segev \& Schlesinger, 1981). Partners spelen een grote rol bij het verwerken van angst, onzekerheid en depressieve gevoelens door de patiënt. Ze bieden sociale ondersteuning. De partners zijn evenwel zelf vaak onzeker. Vandaar dat het nuttig is hen bij de revalidatie te betrekken. Weinig instellingen geven aan dat ze dit consequent doen. In principe kumnen de partners in de meeste centra meedoen met de voorlichtingsprogramma"s.

Samenvattend kan gesteld worden dat in de revaldatie programma's uitgebreid plaats is voor fysieke training. Onderdelen gericht op psychosocialle zorg zijn in ongeveer de helft van de instelingen beschikbaar. Expliciete en systematische aanpak van risicotactoren is in weinig instellingen aanwezig.

Uitgaande van 25.000 patiënten (LMP/SIG, 1989) die na een infarct het ziekenhuis levend verlaten, en van 9.000 patiënten (Begeleidingscommissie Hartchirurgie, 1989) na een hartoperatie, kan gesteld worden dat er 34.000 potentiële kandiclaten voor revalidatie na ontslag zijn. Wanneer aangenomen wordt dat ongeveer 4.000 paliénten zullen weigeren, impliceert dit dat er ongeveer 30.000 kandidaten overblijen. Onze schatting houdt in dat slechts $45 \%$ hiervan een of andere vorm van revalidatie na onts ag uit het ziekenhuis krijgt. Overigens is een dergelike schating in hef buitenland alleen 
bekend wan Canada/Ontario en van de WSNirginia, alwaar in 1983 slechts $15 \%$ van de patienten werd gerevalideerd (Wolfe ea, 1987; Wolfe ea, 1990).

Van de hartinfarctpatienten die het ziekenhuis levend vertaten, is $28 \%$ vrouw (7.007 van de 24.629 patienten) (LMR/SIG, 1989). Aangezien vrouwen met revalidatie beter herstellen dan zonder, (Bär ea, 1992) is de stijging van het aantal vrouwelijke revalidanten toe te juichen. Overigens komt het percentage vrouwen ten opzichte van mannen met een hartinfarct dat het ziekenhuis levend verlaat ongeveer overeen met het percentage vrouwen dat daadwerkelijk gerevalideerd word na ontslag ( $28 \%$ en $26 \%$ ).

In 1970 waren de programma's gericht op "jongere" patiënten beneden de $50-55$ jaar die een ongecompliceerd hartinfarct met een lange immobilisatie fase overleefd hadden: de "low-risk"-patienten (Bär \& Vonken, 1990). Het hoofddoel van de revalidatie toen was werkhervatting door middel van fysleke reconditionering. Dit idee is inmiddels door de steeds vroegere start van de revalidatie en het beperkte nut van revalidatie ten aanzien van de werkherwatting grotendeels verlaten.

Nu worden ook andere doelen nagestreefd, genoemd is reeds herstel van functioneren. verder psychoscciale verbetering en secundaire preventie (Bär \& Vonken, 1990), Dit is echter nawwelijks te merken aan de programma's. Patiënten mel complicaties of een groot infarct werden in het verleden uitgesloten. Dit beleid is geleidelijk gekenterd. Ook een aantal van deze patiënten krijgt nu een vorm van revalidatie.

Slechts naar schatting $17 \%$ van de gerevalideerden is ouder dan 70 jaar, terwill het percentage van de hartinfarctpatiënten, dat levend hel ziekenhuis verlaat en ouder is dan 70 jaar, $34 \%$ is ( 8.450 vain de 24.629 intarctpatiënten) (LMR/SIG, 1989). Overigens is het percentage oudere revalidanten na ontslag pas de laatste jaren gestegen: van $5 \%$ in 1985 tot $17 \%$ in 1988. In de praktijk wordt er blikbaar nog vaak vanuit gegaan dat het revalideren van oudere patiënten niet zinvol is. Hillebrand en Vermeulen (1981) en Bär ea (1992) geven aan dat deze gedachte onjuist is. Anderzijds zijn thet juist de ouderen die weinig gemotiveerd zijn om mee te doen. Zeker is dat vooral door de vergrijzing van de bevolking de behoefte aan revalidatie zal toenemen.

De patiëntenpopulatie van de dagbehandelingsafdelingen onderscheidt zich, in tegen. stelling tot de klinische afdelingen, niet van de patiëntenpopulatie wan de niet-erkende afdelingen betreffende indicatie, leeftijd en geslacht!

\subsection{CONCLUSIES}

Dit onderzoek biedt een uitgebreid en betrouwbaar beeld van de instellingen in Nederland die hartrevalidatie geven na ontslag uit het zlekentuis, en van de daarbij betrokken programma onderdelen. Hoewel in het buitenland deze revalidatiefase ook onderzocht is, zijn de daar verkregen gegevens beperkt in omvang en slechts bekend van een paar landen; bovendien waren deze onderzoeken gemiddeld veel minder diepgaand.

Nederland kent een grote diversiteit aan instellingen (afdelingen voor klinische revalida. tie, revalidatiedagbehandelingsafdelingen, afdelingen met fysieke reconditionering en 
een beperkt psychosociaal programma, afdelingen met alleen een fysiek programma) en aan programma-onderdelen (medische begeleiding, fysieke groepstraining, psychosociaal groepsprogramma, individuele psychosociale begeleiding, individuele consulten door diëtiste).

In principe zijn in Nederland alle typen instelingen en behandelonderdelen aanwezig voor een adequate aanpak van hartrevalidatie na ontslag. De verdeling en de beschikbaarheid over het hele land is echter onevenredig. Daar komt nog bij dat een gerichte indicatiestelling ontbreekt. Herordening en systematische indicatiestelling is noodzakelijk, omdat verwijzing nu teveel op basis van toeval plaatsvindt.

Tevens bestaat er in de praktijk een grote variatie in het percentage patiènten dat gerevalideerd wordt. Krijgen patiënten revalidatie dan houdt dat standaard medische controle plus fysieke training in. Het percentage deelnemers aan de andere behandelonderdelen varieert in hoge mate. Debet hieraan is dat het doel van revalidatie onvoldoende duidelijk geformuleerd is. Deze grote variatie in deelname aan de revalidatie en de verschillende behandelonderdelen daarbinnen is onwenselijk. Richtlijnen zijn nodig betreffende het selecteren van patiënten voor de verschillende onderdelen. 


\section{HOOFDSTUK 5}

\section{Nazorg}

\subsection{INLEIDING}

Dit deel wan het onderzoek had als doel inzicht te verkrijgen in de organisatie en de omvang van de nazorg voor hartpatiënten. Hierbij zijn de "wilde", niet geïnstitutionaliseerde en niet georganiseerde sportclubs buiten beschouwing gelaten, omdat gegevens over deze clubs nauwelijks te achterhalen zijn.

\subsection{VRAAGSTELLING}

Het onderzoek geschiedde middels een schriftelijke enquête (zie bijlage IV), die gericht was op de volgende vragen: (a) Welke instellingen/verenigingen/organisaties geven nazorg? Hoe zijn ze georganiseerd? Welk werkgebied bestrijken zij? Zijn ze aangesloten bij een landelijke koepel? Wat zijn de financiële bronnen? Welke patiënten kunnen lid worden? (b) Welke programma's worden aangeboden? Op welk tijdstip na het incident kan gestart worden met de activiteiten? (c) Hoeveel leden hebben de organisaties? (d) Hoeveel patiënten met welke kenmerken nemen deel aan nazorgactiviteiten?

\subsection{METHODE}

In de eerste helft van 1990 werd de enquête gestuurd naar de organisaties waarvan bekend was dat ze nazorg gaven die specifiek bedoeld was voor hartpatienten. De vragen betroffen het jaar 1989 . Indien het antwoord niet binnen acht weken retour was, werd een schriftelijke herinnering gestuurd. De volgende verenigingen en organisaties werden benaderd:

(a) Patiëntenverenigingen, aangesloten bij de Federatie van Nederlandse Verenigingen van Voor-en Nazorg bij Hartpatienten (FNVVNH, in het vervolg Federatie genoemd).

(b) Patiëntenverenigingen die niet bij de Federatie zijn aangesloten (Overige).

(c) Landelijke Vereniging voor Thuiszorg (LVT). De enquête-formulieren werden gestuurd naar de coördinator van de door de LVVT landelijk gegeven cursussen. 
(d) De Hartenark.

(e) Trimclubs, aangesloten bij Hart In Beweging (HB).

(1) Hef Prowinciaal Steunpunt Bewegingsactiviteiten Gezondheidszorg Limburg (PSBG) te Siltard. Gegevens zijn verkregen via uitgebreide jaarverslagen van de instelling zelf (PSBG, 1988 en 1991).

\subsection{RESULTATEN}

\subsubsection{Respons}

De totale respons was $91 \%$.

(a) De Federatie: hierbij zijn 13 verenigingen aangesloten (FNVVNH, 1990). Zij is in 1985 opgericht en ondersteunt de aangesloten organisaties; daarnaast helpt ze actief bij de oprichting van nieuwe verenigingen. $12(92 \%)$ van de 13 verenigingen respondeerden.

(b) Overige: deze verenigingen zijn vergelijkbaar met die welke aangesloten zijn bij de Federatie. Alle 11 verenigingen respondeerden.

(c) De LVT: een professionele organisatie die bestaat sinds 1990. Ze is ontstaan uit een fusie tussen de Nationale Kruisvereniging en de Centrale Raad voor de Gezinsverzorging. De LVT geeft in verschillende regio's voorlichtingscursussen voor hartpatiënten (Leeuwen van ea, 1986). Alle 9 afdelingen reageerden.

(d) De Hartenark: opgericht in 1977. Geeft bijscholing aan beroepskrachten die werkzaam ziln ten behoeve van hartpatiënten; zet verder patiëntenprojecten op, waaronder voorlichtingscursussen (Kromme de-van der Klis, 1982). Ook de Hartenark vulde de enquête in.

(e) Het HIB: hierbij zijn 99 clubs aangesloten. Het HIB, in 1977 opgericht, is een samenwerkingsverband van plaatselijke recreatiesportverenigingen van ex-hartpatiënten (HIB, 1989a). 82 (83\%) wan de 99 sportclubs respondeerden.

(1) Het PSBG: alleen de provincie Limburg kent een dergelike organisatie, die bewe. gingsactiviteiten voor onder andere hartpatiënten ondersteunt. Er zijn 70 sportclubs bij aangesloten, waarvan 45 tevens deel uitmaken van een patiëntenvereniging. Het gaat daarbij om sport, trim-en zwemclubs. De organisatie is ondergebracht bij het Limburgse Groene Kruis. Van alle 70 aangesloten sportclubs zijn gegevens verkregen.

\subsubsection{Onderzoeksgegevens}

\section{Organisaties}

\section{Startiaar}

De eerste activiteiten zijn al in 1970 door het HIB ontwikkeld (tabel I). De patiëntenverenigingen van de FEDERATIE en OVERIGE zijn midden zeventiger jaren opgericht. De LVT is in de tachtiger jaren gestart met haar activiteiten, evenals de PSBG sportgroepen. 


\section{Tabel I}

Startjaar nazorgactiviteiten per type organisatie

\begin{tabular}{lllll}
\hline Startaar & $\begin{array}{l}\text { Federatie } \\
(N=9)\end{array}$ & $\begin{array}{l}\text { Overige* } \\
(N=9)\end{array}$ & $\begin{array}{l}\text { HIB } \\
(N=73)\end{array}$ & $\begin{array}{l}\text { LVT } \\
(N=10)\end{array}$ \\
\hline $1966-1970$ & 0 & 0 & 2 & 0 \\
$1971-1975$ & 1 & 0 & 1 & 0 \\
$1976-1980$ & 3 & 1 & 13 & 0 \\
$1981-1985$ & 3 & 8 & 24 & 3 \\
$1986-1990$ & 2 & 0 & 34 & 7 \\
\hline
\end{tabular}

"Federatie van Nederlandse Verenigingen Voor- en Nazorg bij Hartpatienten; "* niet bilj de Federatie aangesloten verenigingen: \#art in Beweging; \# Landelike Vereniging Thuiszorg.

\section{Werkgebied}

Er zijn vier patiëntenverenigingen uit de categorie OVERIGE die een landelijke functie hebben: de Vereniging van Vaatpatienten, de Belangenvereniging voor Nederlandse Hartgetransplanteerden "Harten Twee", de Stichting Nederlandse Hartpatiënten en de Stichting " "Cardiogram", die zich alleen bezighoudt met het op landelijk niveau uitgeven van een periodiek dat gericht is op voorlichting voor hartpatiënten.

De Hartenark geeft zijn patiëntenvoorlichtingsgroepen ten behoeve van patienten uit het hele land. De sport- cq trimclubs aangesloten bij het HIB of PSBG (alleen provincie Limburg) werken alle plaatselik, evenals de provinciale c.q. districtsafdelingen van de LVT, die voorlichtingsgroepen geven. Lang nlet alle gezondheidsregio"s (Meegdes, 1988) worden evenredig bediend. Zuid-Limburg heeft in vergelijking met de rest van het land veel meer patiëntenverenigingen en sportgroepen.

Een deel van de sportactiviteiten van de patiëntenverenigingen (Federatie en Overige) valt onder de auspiciën van het HIB of het PSBG: drie patientenverenigingen organiseren hun sportactiviteiten met behulp van het HIB. In Limburg worden 45 van de 70 (64\%) bi] het PSBG aangesloten sportgroepen georganiseerd onder de paraplu van patiëntenverenigingen, alkomstig uit de categorie Overige.

\section{Financiering}

De meest voorkomende vorm van financiering is het contributieheffen van de leden/deelnemers. Voor de meeste sportclubs vormt dit urijwel de enige inkomstenbron. Daamaast levert de overheid (meestal de gemeente) in veel gevallen een bijdrage. Maar ook via andere, vaak creatieve, oplossingen blijken veel patiëntenverenigingen hun financieën aan te vullen: via sponsors, callectes, reclame en advertenties in hun periodiek.

De meerderheid zegt voldoende financiën te hebben om hun doelstellingen te kunnen realiseren: niettemin gewen velen aan dat zij hun activiteitenpakket zouden uitbreiden, indien er meer financiële armslag zou zijn.

Het bestuur van zowel de Federatie als het HIB bestaat uit vrijwilligers. Beide krijgen subsidie wan de Nederlandse Hartstichting, het HIB ook van het Ministerie van WVC. 


\section{Tabell}

Spreiding over Nederland per gezondheidsregio van de verschillende typen organisaties die nazorg geven

\begin{tabular}{|c|c|c|c|c|c|c|}
\hline Gezondheidsregio & Aantal inwoners & $\begin{array}{l}\text { Fed } \\
(N=12)\end{array}$ & $\begin{array}{l}O W^{* *} \\
(N=11)\end{array}$ & $\begin{array}{l}H B^{\#} \\
(N=99)\end{array}$ & $\begin{array}{l}\text { PSBG" } \\
(N=70)\end{array}$ & $\begin{array}{l}L V T^{4} \\
(N=9)\end{array}$ \\
\hline 1. Groningen & 556.757 & 7 & & 5 & & \\
\hline 2. Friesland & 599.104 & $\mid-1$ & & 6 & & \\
\hline 3. Drene & 436.586 & J & & 1 & & 6 \\
\hline 4. Zwalle & 472.014 & 1 & & 2 & & 1 \\
\hline 5. Twente & 569.704 & & & 2 & & \\
\hline 6. Stedendriehoek & 448.820 & & & 6 & & \\
\hline 7. Arntiem & 838.115 & 7. & & 6 & & 5 \\
\hline B. Nimegen & 432.086 & ]$^{-1}$ & & 3 & & \\
\hline 9. Whecht & 1.009 .929 & 1 & & 11 & & \\
\hline 10. Flevoland & 193.739 & & & 2 & & \\
\hline 11 . & 252.643 & & & 1 & & \\
\hline 12. Akmaar & 545.436 & 1 & & 3 & & 1 \\
\hline 13. Kennemerland & 375.562 & 7.1 & & 3 & & \\
\hline 14. Arnsterdam & 1.194 .754 & ]$^{-1}$ & & 4 & & 1 \\
\hline 15. Leiden & 470.913 & & & 4 & & 1 \\
\hline 16. Den haag & 680.391 & & 1 & 2 & & $1+1$ \\
\hline 17. Dellt & 247.657 & & & & & \\
\hline 18. Midden-Holland & 219.921 & & & 2 & & \\
\hline 19. Rijnmond & 1.191 .080 & 7. & & 6 & & \\
\hline 20. Dordrecht & 351.940 & ]$^{-2}$ & & 3 & & \\
\hline 21. Zeeland & 355.501 & & & 5 & & \\
\hline 22. Breda & 601.836 & 1 & & 2 & & \\
\hline 23. Tilburg & 376.468 & & & & & \\
\hline 24. Den Biosch & 578.154 & & & 8 & & \\
\hline 25. Eindhoven & 642.345 & 2 & & 5 & & 3 \\
\hline 26. N-Limburg & 440.610 & 1 & $11 / 2$ & 4 & 29 & \\
\hline 27. Z-Limburg & 631.464 & & $41 / 2$ & 4 & 41 & \\
\hline Totad & 14.714 .948 & & & & & \\
\hline Landelijk workend & & 4 & & & & \\
\hline
\end{tabular}

'Provinciaal Steunpunt Bewegingsactiviteiten Gezondheidszorg; "Federatie van Nederlandse Verenigingen Voor- en Nazorg bij Harpatienten; *A- niet bul de Federatie aangesloten verenigingen; \#art in Beweging; \# Landelike Vereniging Thuiszorg.

Voor het PSBG werken enkele betaalde medewerkers. De Hartenark heeft acht mede. werkers in dienst, die allen door de NHS betaald worden; dit geldt ook voor de accommodatie in Bilthoven. Echter hun activiteiten richten zich niet alleen op hel gebied van hantrevalidatie. De LVT wordt gefinancierd via de AWBZ. 


\section{Tabel III}

Soorten financiering van de verschillende organisaties die nazorgactiviteiten geven

\begin{tabular}{|c|c|c|c|c|}
\hline Financiering & $\begin{array}{l}\text { Federatie: } \\
(\mathrm{N}=12)\end{array}$ & $\begin{array}{l}\text { Overige" } \\
(N=11)\end{array}$ & $\begin{array}{l}M B^{4} \\
(N=79)\end{array}$ & $\begin{array}{l}\mathrm{LVT} T \\
(N \mathrm{~N}=9)\end{array}$ \\
\hline Donatiesicontributies & 12 & 10 & 73 & 9 \\
\hline Subsidie overhevi & 4 & 3 & 24 & 0 \\
\hline Activitelten & 1 & 3 & 8 & 2 \\
\hline Subsidie stichtingen & 0 & 2 & 10 & 0 \\
\hline Industriesponsoring & 1 & 3 & 7 & 0 \\
\hline Collecterinzamelacties & 0 & 1 & $\mathrm{~B}$ & 0 \\
\hline
\end{tabular}

"Federatie van Nederiandse Verenigingen Voor-en Nazorg bij Haltpatienten; "* niet bij de Federatie aangestoten verenigingen; Hart In Beweging; Landelijke Vereniging Thuiszorg.

\section{Tabel IV}

Soorten leden van patiëntenverenigingen

\begin{tabular}{|c|c|c|}
\hline Leden & $\begin{array}{l}\text { Federatie } \\
(N=12)\end{array}$ & $\begin{array}{l}\text { Overige } \\
(N=11)\end{array}$ \\
\hline Alle hartpatienten & 12 & 5 \\
\hline Pathänen na harttransplantatie & 0 & 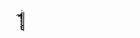 \\
\hline Vaalpatiënten & 0 & 1 \\
\hline Partners & $\theta$ & 5 \\
\hline Professionals & 7 & 2 \\
\hline Geen leden & 0 & 4 \\
\hline
\end{tabular}

"Federatie van Nederiandse Verenigingen Voor- en Nazorg bij Hartpatienten; "* niet bij de Federatie aangesloten verenigingen.

\section{Leden}

Het HIB, het PSBG en de Hartenark hebben geen leden. Het LVT wel, maar dat zijn niet alleen hartpatiènten. Verder kunnen hartpatiënten lid worden van alle patiëntenverenigingen die horen bij de Federatie en van vijf van de elt patiëntenverenigingen wit de categorie Overige. Meestal mogen ook partners lid worden. De andere zes verenigingen uit de categorie Overige hebben alle een stichtingsvorm en telien dus geen leden.

\section{Stant na ontslag}

De meeste patiëntenverenigingen en sponclubs geven aan clat patiënten in principe direct na afloop van de ziekenhuisopname zouden mogen starten met sportactiviteiten; bij sommige andere kan dit pas na de revalidatieperiode. Voor deelname aan de meeste sportactiviteiten is wel (schriftelijke) toestemming van de cardioloog nodig. De kruisverenigingen starten drie tot zes maanden na ontslag uit het ziekenhuis met hun voorlichtingscursussen, de Hartenark houdi ongeveer 4 maanden na opname aan. 


\section{Tabel $\mathrm{V}$}

Soorten doelgroepen van de verschillende typen organisaties die nazorg geven

\begin{tabular}{|c|c|c|c|c|c|c|}
\hline Doeigroepen & $\begin{array}{l}\text { Fed }^{*} \\
(N=12)\end{array}$ & $\begin{array}{l}O N^{* m} \\
(N=11)\end{array}$ & $\begin{array}{l}\mathrm{HIB}^{\mathrm{H}} \\
(\mathrm{N}=75)\end{array}$ & $\begin{array}{l}\left(V^{+1 \# *}\right. \\
(N=9)\end{array}$ & $\begin{array}{l}\text { PSBG } \\
(N=25)\end{array}$ & $\begin{array}{l}\text { HART:" } \\
(N=1)\end{array}$ \\
\hline Alle hartpatiénten & 12 & 9 & 75 & 9 & 25 & 1 \\
\hline Palienten ra hartiransplantatie & 0 & 1 & 0 & 0 & 0 & a \\
\hline Vaatpatienten & 0 & 1 & 0 & 0 & 0 & $a$ \\
\hline Partiners & $\$ 1$ & 8 & 27 & 12 & 0 & 1 \\
\hline Professionals & 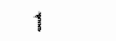 & 1 & 11 & 0 & 0 & 1 \\
\hline
\end{tabular}

'Provinciaal Steunpun! Bewegingsactiviteiten Gezondheidszorg: "Hartenark; "Federatie van Nederlandse Verenigingen Voor- en Nazorg bỉ Hartpatienten; *" niet bij de Federatie aangesloten verenigingen: Hart In Beweging; \#andelike Vereniging Thuiszorg.

\section{Doeigroepen}

Eên patientenvereniging richt zich specifiek op vaatpatiënten en éen uitsluitend op hartgetransplanteerden. De activiteiten van de meeste andere patiëntenverenigingen/groepen zijn voornamelijk gericht op patiënten na infarct of operatie, een enkele keer ook op andere patiënten (harttransplantatie, PTCA en vaatpatiënten).

Bij de voorlichtingsactiviteiten van de LVT worden de partners uitdrukkelijk uitgenodigd. Dal geldt ook voor de meeste activiteiten van de Federatie, de patiëntenverenigingen die valien in de categorie Overige en de Hartenark. Slechts eenderde van de sportgroepen van het HIB laten partners toe. Bij de PSBG-bewegingsgroepen is $23 \%$ van de deelnemers partner.

\section{Activiteiten voor patiënten}

Het HIB en het PSBG houden zich in principe alleen bezig met sportgroepen. Het LVT en de Hartenark, beide professionele organisaties, geven uitsluitend cursussen gericht op secundaire preventie. De patientenverenigingen geven het hele scala aan activiteiten (Tabel Vl), zoals:

(a) Sport- en trimgroepen: de meest voorkomende activiteit. In verschillende vormen mogelik: sport en spel, gymnastiek of zwemmen. Doel is meestal niet de prestatie, maar het (weer) plezier krijgen en houden in bewegen.

(b) Voollichtingsgroepen: hierin wordt, ook door professionals, voorlichting gegeven over de hartziekte en over risicofactoren aan patienten en hun partners. Tevens wordt aandacht besteed aan gedragsverandering en het uitwisselen van ervaringen.

(c) Emotionele ondersteuning door lotgenoten: vrijwilligers, die zelf hartklachten (gehad) hebben en daar emotioneel enige afstand van konden nemen, worden opgeleid om patienten individueet te ondersteunen bij hun verwerkingsproces.

(d) Ontspannings., wrijetijdsactiviteiten: het betreft hier zowel incidenteel als regelmatig terugkerende activiteiten. Incidenteel: bijvoorbeeld sportdag, gezellige avond, nieuwjaarsteest. Regelmatig: bijvoorbeeld een soos middag/awond, biljartclub. 


\section{Tabel VI}

Aard van nazorgactiviteiten verzorgd door de verschillende typen nazorgorganisaties

\begin{tabular}{|c|c|c|c|c|}
\hline Soort activiteit & $\begin{array}{l}\text { Federatie } \\
\text { en overige" } \\
(N=22)\end{array}$ & $\begin{array}{l}H B^{4} \\
\text { en PSBG } \\
(N=99)\end{array}$ & $\begin{array}{l}\text { LVT } \\
(N=12)\end{array}$ & $\begin{array}{l}\text { HART" } \\
(N=1)\end{array}$ \\
\hline Sport & $17(77 \%)$ & $99(100 \%)$ & 0 & 0 \\
\hline Voorlichtingsgroepen & $11(50 \%)$ & 0 & $12(100 \%)$ & 1 \\
\hline Individuele psychosociale zarg & $6(27 \%)$ & 0 & 0 & 0 \\
\hline Vrije tijd activiteiten & $7(32 \%)$ & $17(17 \%)$ & 0 & 0 \\
\hline Individuele belangenbehartiging & $11(50 \%)$ & 0 & 0 & 0 \\
\hline Collectieve belangenbehartiging & $6(27 \%)$ & 0 & 0 & 0 \\
\hline
\end{tabular}

"Prowinciaal Steunpunt Bewegingsactiviteiten Gezondheidszorg: " Hartenark; "Federatie van Nederland. se Verenigingen Voor- en Nazorg bij Hartpatiëntem; "* niet bij de Federatie aangeslaten verenigingen; Hart In Beweging: \#andelike Vereniging Thuiszorg.

(e) Individuele belangenbehartiging: patiënten (en partners) die in financiële nood komen doordat ze hartpatiënt zijn geworden, kumnen bij sommige verenigingen een beroep doen op een speciaal fonds. Daarnaast wordt juridische hulp geboden bij WAO. en zlektewetprocedures. Verder wordt geholpen bil klachten over medische zorg.

(f) Collectieve belangenbehartiging: denk bijwoorbeeld aan de luchibrug voor hartpatiënten bij lange wachtlijsten.

\section{Wie verzorgen de activiteiten?}

Bil patiëntenverenigingen van de Federatie en uit de categorie Overige worden alle bestuurswerkzaamheden door wrijwilligers, meestal ex-patiënten, verricht. Sportactiviteiten gegeven door sportgraepen aangesloten bij het HIB of het PSBG, worden meestal begeleid door gediplomeerde begeleiders. Dit kumnen zowel betaalde als niet-betaalde krachten zijn. Onduidelijk is of dat ook geldt voor de sportgroepen die vallen onder de patiëntenverenigingen. Ten behoeve van de voorlichtingscursussen worden doorgaans professionals ingehuurd om onderdelen hiervan te verzorgen, zoals cardiologen, psy. chologen, diëtisten etc.

\section{Patiëntenaantallen}

Voorafgaande aan de presentatie van de gegevens dient opgemerkt te worden dat de verstrekte gegevens kwantitatief zeer beperkt zijn. Bovendien zijn het vaak schattingen geweest.

\section{Aantal leden}

De patiëntenverenigingen aangesloten bij de Federatie hebben samen 5.337 leden $(\mathrm{N}=12)$. De patiëntenverenigingen uit de categorie Overige tellen 1.212 leden $(N=7)$. De verhouding man-wrouw bij de Federatie is $60 \%-40 \%(\mathrm{~N}=9)$, bij de Owerige $70 \%-30 \%$ $(N=7)$. 


\section{Tabel VII}

Aantal deelnemers per nazorgactiviteit per type nazorgorganisatie

\begin{tabular}{|c|c|c|c|c|c|}
\hline Soort actimeit & $\begin{array}{l}\text { Federafle" } \\
\text { wn ovenge } \\
(N=23)\end{array}$ & $\begin{array}{l}H \mathrm{HB}^{\text {f }} \text { en } \\
\mathrm{PSBG}^{\circ} \\
(\mathrm{M}=169)\end{array}$ & $\begin{array}{l}L W T^{i f+t} \\
(N=9)\end{array}$ & $\begin{array}{l}\text { HART: } \\
(\mathbb{N} \mid=1)\end{array}$ & $\begin{array}{l}\text { Tolaal } \\
\text { (N-202) }\end{array}$ \\
\hline Sport & $\begin{array}{l}2.500 \\
(N=12)\end{array}$ & $\begin{array}{l}5.416 \\
(N=143)\end{array}$ & 0 & 0 & 7.916 \\
\hline Voorlichtingsgroepen & $\begin{array}{r}246 \\
(N=6)\end{array}$ & 0 & $\begin{array}{l}214 \\
(N=8)\end{array}$ & $\begin{array}{l}250 \\
(N=1)\end{array}$ & 710 \\
\hline Lotgenoten ondersteuning & $\begin{array}{r}365 \\
(N=3)\end{array}$ & 0 & 0 & 0 & 365 \\
\hline Vrije fijd activiteiten & $\begin{array}{r}755 \\
(\mathbb{N}=6)\end{array}$ & $\begin{array}{c}542 \\
(N=12)\end{array}$ & 0 & 0 & 1.297 \\
\hline Indwiduele belangenbehartiging & $\begin{array}{r}73 \\
(N=5)\end{array}$ & 0 & 0 & 0 & 73 \\
\hline
\end{tabular}

"Provinciaal Steunpunt Bewegingsactiviteiten Gezondheidszorg:" Hartenark; "Federatie van Nederlandse Verenigingen Voor- en Nazorg bij Hartpatie̊nten: " niet bij de Federatie aangesloten verenigingen;

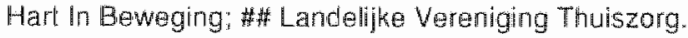

\section{Aantal deelnemers}

(a) Sportactiviteiten: in totaal namen bijna 8.000 deelnemers regelmatig deel, meestal wekelijks. Dit aantal is gebaseerd op een respons van 12 van de 17 patiëntenverenigingen die sportactiviteiten geven, en op een respons van 73 van de 99 clubs die bij het HIB zijn aangesloten en de 70 clubs die bij het PSBG zijn aangesloten. Een schatting van de totale populatie kamt uit op 10.000 deelnemers.

Bij het HIB was de verhouding man-vrouw: $85 \%-15 \%$; bij het PSBG $64 \%-36 \%$.

(b) Voorlichtingsgroepen: in totaal hadden ongeveer 710 patiënten voorlichting in groepsverband genoten.

(c) Zes verenigingen gaven aan dat ze emotionele ondersteuning door lotgenoten verzorgen: 365 mensen ( $N=3$ ) kregen een dergelijke begeleiding.

(d) Ontspanmingsactiviteiten: bijna 1.300 patiënten namen hieraan deel.

(e) Individuele belangenbehartiging: elf hartpatiëntenverenigingen gaven aan deze vorm van service te bieden. Slechts vijt konden cijfers leveren waarbij in totaal 73 mensen zouden zijn geholpen. 


\subsection{DISCUSSIE}

\subsubsection{Dataverzameling en beperkingen}

Gezien de grote respons $(91 \%)$ kan gesteld worden dat een wrijwel compleet beeld geschetst is van de bekende organisaties en hun activiteiten in Nederland. In mindere mate geldt dit voor de patiëntenaantallen: de respons hierop lag een stuk lager (zie tabel VII), waarbij de cilfers gebaseerd werden op retrospectieve schattingen.

Een nadeel van dit onderzoek is dat de data zijn geleverd door de verenigingen en sportgroepen zelf. Het is zeer wel mogelijk dat sociale wenselijkheid een rol gespeeld heeft bij het invullen van de enquêtelijsten: men kan de neiging hebben de situatie rooskleuriger voor te stellen dan ze in werkelijkheid is. Er dient echter in acht genomen te worden dat dit een van de eerste Nederlandse onderzoeken is naar de nazorgfase. Schäperclaus ea (1991) hebben de nazorgfase in Nederland ook geinventariseerd, waarbij ze zich beperkt hebben tot sportactiviteiten. Hun respons was $94 \%$.

In het buitenland is alleen in West-Duitsland zo'n onderzoek naar sportgroepen gedaan. in 1982 (Gleichmann, 1983). De respons bedroeg 67\%. Schäperclaus e.a. (1991) hebben in 1990 een inventariserend onderzoek gedaan naar de sportgroepen voor hartpatiënten in Duitsland. Ze deden dat op basis van een steekproef van 280 verenigingen (totaal 2.500 ) en kregen een respons van $63 \%$. Mogelijk dat dit de data minder betrouwbaar heeft gemaakt.

\subsubsection{Beschouwingen}

De activiteiten en de organisaties zijn niet evenredig verdeeld over het lland. Zo zijn er in bepaalde regio's blinde vlekken, terwijl in Zuid-Limburg een keur aan organisaties actief is, die elkaar mogelijk zells voor de voeten lopen. Sportgroepen zijn in verhouding het meest frequent aanwezig en nagenoeg alle regio's van het land zijn voorzien. In dit opzicht wordt voldaan aan de doelstelling dat de effecten van revalidatie gestabiliseerd dienen te worden. Er ziln nauwelijks activiteiten die het psychosociaal herstei kunnen bestendigen; op sporadische plekken wordt emotionele ondersteuning door lotgenoten geboden. Ook voor het vervolgen van het veranderen van risicogedrag worden weinig activiteiten gegeven: in enkele regio's worden voorlichtingsgroepen gegeven.

Sturing en afstemming op organisatorisch niveau lijkt nuttig om meer (ex)patiënten te bereiken en hen naar de juiste instantie te kunnen verwijzen. Hiertoe dient ook op inhoude lijk niveau selectie, indicatiestelling en zo nodig doorverwijzing van (ex)patiënten plaats te vinden. Dit zou bijvoorbeeld door de huisarts of cardioloog kunnen geschieden. De Federatie (Rooy de \& Comet, 1988) is landelijk actief in hel organisalorisch afstemmen van de patiëntenverenigingen, terwijl het HIB dat doet voor de sportgroepen. Echter nielt voor alle initiatieven bestaat een landelijke afstemming. Het is van belang dat aan alle activiteiten voor hartpatiënten die buiten de reguliere gezondheidszorg vallen, landelijk enige sturing gegeven wordt.

Op provinciaal niveau tracht in Limburg het PSBG sturing te geven aan bewegingsactiviteiten voor hartpatiënten, en probeert het Steunpunt Zelfzorg Initiatieven (Rooy de \& 
Cornet. 1988) de patiéntenverenigingen te stroomlijnen. Ideaal zou zijn dat per ziekenhuis of gezondheidsregio bekend was welke nazorgactiviteiten ter beschikking staan, wat ook een gerichte advisering aan patiënten mogelijk zou maken.

Duitsland is het enige land, naast Nederland, waar inventariserend onderzoek is gedaan naar de nazorgfase. Daar is de organisatie van de hartrevalidatie anders dan in Nederland (Gleichmann ea, 1983). Na de revalidatie tijdens opname in het ziekenhuis, worden de patiënten doorgestuurd voor klinische revalidatie in een revalidatiekliniek gedurende een periode van vier weken (Jette ea, 1988). De ambulante sportgroepen worden gezien als een logische voortzetting op deze twee fasen. Vergeleken met Nederland duurt de revalidatiefase veel korter: vier weken tegen drie maanden in Nederland voor poliklinische revalidatie. In feite hebben de sportgroepen in Duitsland ook een revalidatiefunctie: ze starten vier weken na ontslag uit het opnameziekenhuis. In Duitsland wordt vrijwel alleen fysieke training aangeboden, terwijl in Nederland een breder dienstenpakket mogelijk is.

Uit de cijfers van het PSBG betreffende het aantal sportgroepen in Limburg blijkt dat eenderde hiervan niet aangesloten is bij een hartpatiëntenvereniging of het $\mathrm{HIB}$, en dus "wilde" groepen genoemd kunnen worden. Ook het HIB (1989b) raamt dat er naast de ongeveer 100 bij hen aangesloten clubs nog ruim 40 niet- aangesloten clubs zijn. Uitgaande vam onze schatting van 10.000 deelnemers bij de ons bekende clubs, betekent dit dat er naar alle waarschijnlijkheid in totaal tenminste 14.000 deelnemers waren in 1989 in geheel Nederland. Schäperclaus ea (1991) komen uit op een schatting van 12.000 .

In voormalig West-Duitsland waren in 1982 ongeveer 500 sportclubs voor hartpatiënten en ongeveer 9.000 deelnemers (Gleichmann ea, 1983). In 1991 was dit uitgegroeid tol ongeveer 2.500 sportclubs en ongeveer 55.000 deelnemers (Schäperclaus ea, 1991). Gerelateerd aan het aantal inwoners (Nederland: 14 miljoen, West-Duitsland 60 miljoen) en uitgaande van een gelijke incidentie van hartziekten mag aangenomen worden dat in beide landen eenzelfde percentage hartpatiënten aan sportgroepen deelneemt.

\subsection{CONCLUSIES}

Er bestaat een redelijk beeld van de nazorgfaciliteiten en de organisatie ervan in Nederland. In het buitenland is alleen in het voormalige West-Duitsland onderzoek gedaan naar de nazorg. De nazorgactiviteiten bevinden zich nog in een opbouwfase. De ongelijke landelijke vercleling, de sterk wisselende organisatiegraad en het sterk variërende type hulp dat geboden wordt zijn hier tekenen van. Sportactiviteiten zijn breed beschikbaar. Psychosociale zorg en secundaire preventie zijn uiterst beperkt beschikbaar, waardoor in de praktijk (nog) niet voldaan kan worden aan de doelstellingen van zelfhulpactiviteiten, namelijk het continueren van fysiek en psychosociaal herstel en verandering van risicogedrag. 


\section{Hoofdstuk 6}

\section{Algemene Discussie}

\subsection{INLEIDING}

In dit laatste hoofdstuk worden allereerst de gebruikte onderzoeksmethoden geëvalueerd en volgen er aanbevelingen voor toekomstig onderzoek. Op de tweede plaats worden de in hoofdstuk 3,4 en 5 beschreven onderzoeksresultaten geëvalueerd in het licht van de vigerende definities van hartrevalidatie en het door de jaren heen gevoerde beleid; tevens wordt in het kort ingegaan op de stand van zaken van het effectonderzoek. waarna er aanbevelingen voor de praktijk volgen. Tol slot wordt aangegeven hoe deze aanbevelingen gerealiseerd zouden kunnen worden.

Alvorens op bovenstaande in te gaan zijn hier nog enkele opmerkingen over hartrevalidatie in het buitenland op zijn plaats. Gesteld kan worden dat de hartrevalidatie in Nederland, in vergelijking met het buitenland, ver ontwikkeld is. (zie hoofdstuk 2). Alleen in thet voormalige West-Duitsland kan ook een redelijk compleet en wijdverbreid netwerk van voorzieningen aangetroffen worden. In Nederland is de hartrevalidatie zeer ver on twikkeld als we kijken naar het aantal cq percentage patiënten dat gerevalideerd wordt. Ook is er een uitgebreid en gedifferentiëerd pakket aan behandelvormen aanwezig, dat over het gehele land beschikbaar is.

\subsection{EVALUATIE VAN DE GEBRUIKTE METHODEN VAN ONDERZOEK}

De enquêtes zijn een bruikbaar instrument gebleken om een landelijk overzicht te verkrijgen van omvang en inhoud van de revalidatie. Nadeel is dat de gegevens verstrekt zijn door hoofdzakelijk een discipline, namelijk de fysiotherapeuten. Deze beroepsgroep heeft, evenals andere disciplines, geen compleet overzicht over alle revalidatie-activitelten. Waarschijnlijk zal dit de door ons verkregen data vertekend hebben. Mogelijk dat dit probleem bij een volgende enquêtering ondervangen kan worden door het hele team bij de dataverzameling te betrekken. Een andere nadeel, namelijk het feit dat de data door het team zelf verstrekt zijn, blijft hiermee bestaan. Het team zal een relatief rooskleurig beeld geven van door hen gegeven behandelonderdelen. 
Ook de individuele patientenregistratielijsten zijn door fysiotherapeuten ingevuld. Evenals bij de encuetes geldt hier helzelfde nadeel. Ook her zou dit opgevangen kunnen worden door het hele team bij de dataverzameling te betrekken. Het grote voordeel van de registratielisten is dat hiermee prospectief en dus nauwkeuriger data verzameld zijn. Enerzijds ter validering van de enquêtegegevens, anderzijos een uitbreiding van data. Het leverde een validering op van toegepaste behandelonderdelen, anderzijds gat het uitvoeriger inzicht in wat daadwerkelijk per patient gedaan wordt in het kader van revalidatie. Hieruit bleek dat relatief weinig patiënten andere onderdelen behalve fysiotherapie kregen. Het bleek een relativering, immers uit de enquêtegegevens kwam het beeld te voorschin van een zeer uitgebreid revalidatiepakket tijdens opname en ontslag, waarvan relatief weinig gebruik werd gemaakt.

Verder is met behulp van de individuele patiëntenlijst fase 1 en 2 in onderlinge samenhang geregistreerd, waarbij duidelijk werd hoeveel en welke patiënten vanuit de opname doorvenwezen werden naar een aldeling voor revalidatie na ontslag. Een toekomstig onderzoek zou in een steekproef van representatieve gezondheidsregio's dienen te registreren zowel de overgang van fase 1 naar 2 , alls ook die van 2 naar 3 . In deze dissertatie ligt de nadruk op fase 2, omdat hier de prioriteit wat betreft beleid en bijsturing ligt.

Beide bovengenoemde onderzoeksmethoden hebben het nadeel dat de informatie door professionals verstrekt is en daardoor waarschijnlijk in gunstige $z$ in vertekend is. Een mogelikkeid om dit te ondervangen is de data te valideren met behulp van door patienten zelf verstrekte gegevens. Op basis van een representatieve steekproef uit de beschikbare instellingen zouden patiënten geënquêteerd kunnen worden over wat ze allemaal aan revalidatle gehad hebben en met welke disciplines ze in contact zijn geweest.

De volgende aanbevelingen kunnen gedaan worden ten aanzien van toekomstig inventariserend onderzoek: allereerst lijkt het zinval om periadiek, eenmaal per bijvoorbeeld 3 jaar, alle instellingen en patiëntenorganisaties te enquêteren met het doel een globaal landelijk overzicht te krijgen. Hierbij dient dan wel zo veel mogelijk het hele team betrokken te zinn. Op de tweede plaats is het zinwol om over enkele jaren een registratie met behulp van individuele patiëntenlijsten te herhalen in een representatieve gezondheidsregic, waarbij het gehele traject dat een hartpatient kan doorlopen onder de loupe genomen wordt. Dit kan dan gevalideerd worden met behulp van gegevens verstrekt door patiênten zelf.

\subsection{EVALUATIE VAN DE REVALIDATIE IN NEDERLAND}

\subsubsection{Opnamefase}

De belangrijkste doelstelling van de opname voor de hartpatient is uiteraard de medische zorg; op de tweede plaats volgt herstel van fysiek en psychosociaal functioneren en tenslotte kan er een start gemaakı worden met secundaire preventie. 
De gemiddelde opnameduur is de atgelopen jaren beduidend konter geworden: was deze in 1966 nog gemiddeld vijf a zes weken, in 1988 was deze atgenomen tot slechts 13 dagen (LMP/SIG, 1989). Dit geldt woor zowe patienten na infarct als na coronaire bypassoperatie. Deze fase is korter geworden door verbeterde kennis en medisch technische mogelijkheden en door de bevinding dat de meeste patiënten snel na een infarct of operatie gemobiliseerd konden worden zonder toename van de ziekenhuissterte (Bär \& Vonken, 1990).

Uiteraard is er in alle ziekenhuizen medisch specialistische en verpleegkundige zorg aanwezig. Standaard is verder dat de meeste patiënten door een fysiotherapeut gemo. biliseerd worden. Een kwart van de patienten krijgt tijdens opname of direct na ontslag een inspanningstest. Consultatie door diëtist, maatschappelijk werker en klinisch psycholoog is lang niet in alle ziekenhuizen mogelijk. Waar well mogelijkheden bestaan wordt her geen of slechts beperkt en weinig systematisch gebruik van gemaakt. Systematische aandacht gericht op secundaire preventie is tijdens opname vrijwel afwezig. De aanpak van psychosociale zorg en secundaire preventie is dus athankelik van lokale factoren.

Standaard fysiotherapie bij de meeste patiënten na infarct of bypassoperatie tijdens opname lijkt wenselijk. Voor fysieke training tijdens opname is er een financiering in de vorm van fysiotherapieverrichtingen. Eveneens lijkt een inspanninstest tijdens of direct na opname zinvol (Fioretti ea, $1987 \mathrm{en}$ 1988). Het is van groot belang dat ijdens de opname naast problemen op medisch en fysiek vlak ook psychosociale problemen gesignaleerd worden door specialist, verpleging en fysiotherapeut. Deze kumnen dan poliklinisch daadwerkelijk aangepak worden, door hel team. Hier zou systematische screening bijwoorbeeld door middel van bestaande of nog te ontwerpen vragenlijsten kunnen helpen. Eventueel kan deze screening na ontslag gedaan worden, voor de start van de revalidatie. Ook zou de klinische patientenbespreking hierop gericht kunnen worden.

Overigens is doorverwijzing in dit stadium enerzijds mogelijk nog te vroeg, anderzijds zijn er op psychosociaal gebied aperte probleemgevallen, die tijdens opname in thet ziekenhuis nog niet herkend worden of pas nadien evident worden. Het geat bijvoorbeeld om patienten met ernstige angst-en/of depressiviteitsklachten.

De mogelijkheid voor indiwiduele consulten van maatschappelijk werk, klinisch psycholoog en diëtiste dient tijdens de opname in principe aanwezig te zijn. Het gaat hier vermoedelijk om kleine aantallen patiënten die dit nodig zullen hebben. Wel is nodig dat indicatiecriteria duidelijker geformuleerd worden, omdat deze in de praktijk heel divers geinterpreteerd worden. Op het gebied van secundaire preventie is het aan te bevelen om al tijdens de opname te starten met enkele woorlichtingsbijeenkomsten door cardioloog, verpleegkundige, fysiotherapeut, diëtiste en klinisch psycholoag.

Er dient een financiële regeling te komen woor psychosociale zorg en secundaire preventie tijdens opname. 


\subsubsection{Revalidatie na ontslag}

De belangrijkste doelstelling in deze fase is het herstel van lysiek en psychosociaal functioneren. Daamaast werdient secundaire preventie onder andere door verandering van risicogedrag de aandacht Op de derde plaats moet de medische zorg gecontinueerd worden.

Fysiotherapie in groepen is een standaard onderdeel van het revalidatiepakket. In de praktik duunt dit onderdeel gemiddeld 3 maanden. Individuele fysiotherapie is weinig beschikbaar, behave in centra voor klinische revalidatie. De start van het fysieke programma vindt steeds sneller na ontslag plaats. Het percentage patiënten per ziekenhüs dat revalidatie krijgt variéent sterk.

Individuele consulten door maatschappelijk werk, klinisch psycholoog of diëtist zijn, ondanks het ontbreken van een financieringsregeling, in eenderde van de niet-erkende afdelingen gebruikelijk. Bestaat de mogelijkheid wel dan is er een grote variatie in het aantal patiënten dat voor een consult verwezen wordt. In veel ziekenhuizen wordt weliswaar aandacht besteed aan secundaire preventie, maar vaak ongestructureerd. Slechis in ongeveer een kwart wan de instellingen wordt een groepsprogramma, gericht op secundaire preventie, gegeven.

Deze grote bandbreedte in aantallen en lype zorg zet aan tot nadenken: als in de ene instelling dezelfde patiënt geen revalidatie en in de andere zeer uitgebreide zorg krijgt, wekt dit de indruk dat het nut van revalidatie in deze fase onvoldoende onderbouwd is. Niet alle patiënten moeten alles hebben en daarom is het noadzakelijk om duidelijke richtlijnen te maken omtrent selectiecriteria.

Overigens is het van belang te weten in hoeverre de onderzoeksgegevens, die stammen uit 1988 en verzameld zijn in 1989, nog actueel zijn. Uit een onderzoek dat uitgevoerd werd in 1993 (Senten. submitted for publication) bliki dat de gegevens uit deze dissertatie in grate lijnen overeenkomen met die uil het genoemde onderzoek. Een verschil valt op: anno 1993 blitkt $50 \%$ een of anclere vorm van groepswoorlichting te hebben, terwijl dat 5 jaar eerder nog maar $25 \%$ was.

De opvattingen van Bangma (1987) weerspiegelen het in de praktik toegepaste beleid. Bangma stelde dat behandeling in de zin van bewegingstherapie bij alle patienten steeds is geindiceera! Hievoor werd de regeling "reconditionerende fysiotherapie" ontwikkeld (Ziekentondsraad, 1985). Revalidatie was volgens Bangma geindiceerd als er door functiestoomissen ten gevolge wan hel hartinfarct zodanige beperkingen op het gebied van fysieke onathankelijkheid, maatschappelijk en psychisch functioneren ontstaan dat de kwaliteit van het bestaan van de patiënt ook op langere termijn wordt bedreigd. Hiertoe is het "advies inzake het besluit revalidatiedagbehandeling ziekenfondsverzekering" door de Ziekentondsraad (1981) geformuleerd. Zeer waarschijnlik heeft deze vrij algemene formulering ertoe bijgedragen dat deze regeling toegepast is voor zeer uiteenlo- 
pende indicatiegebieden. In feite heett de overheid haar beleid hierop gebaseerd. Het blikt dat de overheid de initiatieven uit het veld gevolgo heeft.

Vaak is revalidatie in de praktijk een synoniem voor fysieke training. De nadruk op fysiotherapie wordt in feite versterkt door de bestaande financiele regeling (Dixhoom van, 1990).

Daar komt nog bij dat door de jaren heen door de Nederlandse Hartstichting geen eenduidig beleid is gevoerd ten aanzien wan de aanpak van hartrevalidatie: een deel van de leden van de Revalidatie Commissie wilde in het verleden alle patiènten doorverwijzen naar regionale gespecialiseerde afdelingen, terwil een ander deel stelde dat de patiënten in hel eigen ziekenhuis gerevalideerd moesten worden (MHS, 1966 en 1977)! in 1990 is een rapport van de Hartstichting (NHS, 1990) verschenen, waarin een visie ontwikkeld is op hartrevalidatie. Hierin zijn bovengenoemde tegenstellingen geintegreerd.

Een ander belangrijk probleem is dat hel effect van hartrevalidatie na ontslag uit het ziekenhuis zeer ter discussie staat, omdat verschillende doelen voor de hele grcep patiënten worden nagestreefd (NHS, 1990). Dit is ook een belangrijke reden voor de diversiteit in de hartrevalidatie, zoals deze momenteel bestaat.

Gunstig is dat het dagelijks functioneren van hartpatienten die fysieke reconditionering krijgen de eerste drie maanden toeneemt, terwijl dit effect het eerste jaar blijf bestaan. Vooral oudere patiënten, vaak vrouwen, maar ook alleenstaanden blijken hiervan te profiteren. Conditieverbetering is eveneens een reëel effect hiervan. Als de lichamelike activiteiten na het beëindigen van de revalidatie niet gecontinueerd worden, neemt de conditie geleidelijk aan af (Bär ea, 1992). Met uitzondering van meta-analyses (Oldrigde ea, 1988; O'Connor ea, 1989; Collins ea, 1984) laten de meeste onderzoeken geen afname van morbiditeit en mortaliteit zien na een reconditioneringsprogramma. Revali= datie verhoogt de kans op werkhervatting niet (Diederiks, 1982; Vermeulen, 1983; Bär \& Vonken, 1990). Fysieke training leidt op korte termijn tot angstreductie, echter na beeindigen therapie neemt de angst weer toe (Uden van ea, 1986).

De effecten van psychologische interventies zijn erg wisselend en vaak slechts tijdelijk (Uden van ea, 1986; Uniken Venema-van Uden, 1990). Een uitzondering vormt indivi. duele relaxatietraining in combinatie met fysieke inspanningstraining (Dixhoorn van ea, 1990). De effecten van secundaire preventieprogramma's zijn positief, mits gestructureerd en deskundig opgezet (Maes \& Elderen van, 1988).

Zoals uit onderhavig onderzoek blikt is er in Nederland een breed pakket aan behandelmogelijkheden beschikbaar. Echter dit pakket is onevenredig verdeeld over het land. Ook varieert in hoge mate per ziekenhuis in hoeverre van de beschikbare taciliteiten gebruik gemaakt wordt. Vandaar dat het nodig is om per behandelonderdeel indicatie (en contraindicatie) criteria te bepalen. Verder is het van belang dal per individuele patiënt revalidatiedoelen opgesteld worden, zodat deze adequaat doorverwezen kan worden naar een of meer revalidatiemodulen. Deze doeten dienen op fysiek en psycho. sociaal vak vastgesteld te worden en moeten zo sne mogelik na opname bepaald le worden. Ook is het zaak een risicoprofiel per patiënt vast te stellen, zodat deze naar een secundair preventieprogramma doorgestuurd kan worden. 
Hiertoe dienen meetinstrumenten ontwikkeld te worden. Idealiter wordt de behandeling op gezette tijden geevalueerd en zonodig bijgesteld. Verder is dan wel een flexibel financiëel systeem noodzakelik, waarin niet de instelling maar hetgeen de patiënt nodig heeft centraal staat.

Het is zaak dat per patient individuele revalidatiedoelen geformuleerd worden, waardoor het wel mogelik is doelen als conditieverhoging. morbiditeit, angstreductie en vermindering van risicogedrag te realiseren. Revalidatie werkt niet als de hele groep patiënten standaard een vaste therapievorm gegeven wordt om een standaard doel te bereiken.

De fasering van het zorgtraject rondom de hartpatient is primair gebaseerd op fysiek herstel. Bij de opzel, zoals deze gegroeid is door de jaren heen, is geen rekening gehouden met de gemiddelde duur van het psychisch verwerkingsproces van zes tot twaalf maanden (Rooymans, 1979) en met de verandering van risicogedrag dat nog veel langer duurt.

Was in 1984 nog het adagium dat iedereen alles nodig had en dat de hartrevalidatiefaciliteiten daarom in deze geest uitgebreid zouden moeten worden, anno 1995 is het parool te differentieren welk onderdeel voor welke patiënt aangewezen is. Cruciaal hiervoor is adequate selectie. Deze nieuwe aanpak hoeft niet per se duurder te zijn dan de huidige kosten die gemaakt worden voor de zorg van hartpatiënten (NHS, 1990).

De beslissing wie woor welke vorm van revalidatie na ontslag in aanmerking komt, vall idealliter aan het eind van de ziekenhuisfase. Het is verstandig om tijdens de revalidatiefase te bekijken wat er bereikt is en of het nodig en nuttig is met dit of een ander programma door te gaan. Een multidisciplinaire aanpak is aangewezen. Coördinatie hierwan is, indien aanwezig, de verantwoordelijkheid van de revalidatiearts, anders van de cardioloog. Het verdient de voorkeur de beoordeling van psychosocialle gegevens onder verantwoordelijkheild van een klinisch psycholoog te laten vallen (NHS, 1990). Het instrumentarium voor psychosociale screening is op dit moment nog onvoldoende ontwikkeld.

In een nieuwe aanpak (NHS, 1990), waarin de patient centraal staat zouden de volgende mogelijkheden beschikbaar kunnen zijn:

(a) De gangbare begeleiding door de cardioloog met inschakeling van de huisarts. Overigens is een betere afstemming tussen deze twee disciplines gewenst (Vlek ea, 1994).

Voor patiënten bij wie geen discrepantie bestaat tussen het gewenste en het feitelijke functioneren terwijl behandelbare risicofactoren ontbreken is dit aangewezen. Of woor patiënten bij wie, gezien bijvoorbeeld de hoge leeftijd, behandeling niet bijster zinvol is. Ook dient hiermee te worden volstaan indien patiënten weigeren aan revalidatie activiteiten mee te doen.

(b) Een optie die verdient verder uitgezocht te worden is begeleiding door een, nog niet bestaande, revalidatieverpleegkundige die adviezen geeft op het gebied van dagelijkse activiteiten en controleert of de adviezen worden opgevolgd. Dit is zeker zinvol in kleinere 
centra die niet een volledig team kunnen laten draaien. Dit is een benadering die overigens ook in combinatie met revalidatieprogramma's opgezet kan worden. Deze verpleegkundige kan het lange termijn werk op zich nemen. Het is zaak dat er een goede afstemming plaatsvindt met andere disciplines.

Indien geen revalidatie plaatsvindt kan een revalidatieverpleegkundige adviezen geven aan patiënten met een ongecompliceerd myocardinfarct, dat geen beperkingen oplevert. waarbij geen angina pectoris, ritme-, geleidings-en pompfunctiestoomissen of andere beperkende lichamelijke problemen aanwezig zijn. Verder geldt deze behandeling voor ouderen, psychisch stabiele patiënten die, naar verwachting, verstandig omgaan met adviezen en een goed ziekte-inzicht hebben, en patiënten die alleen durven oefenen.

(c) Lichamelijke conditietraining door middel van een (standaard) cetenprogramma in groepsverband onder leiding van een fysiotherapeut. Het programma voorziet zowell in conditietraining als in ontspanningsoefeningen en kan, indien nodig, tot op zekere hoogte per individu worden verlengd of verkort.

Dit type revalidatie is bedoeld voor "standaard" patiënten van wie het dagelijks functio. meren onvoldoende is, mits geen "grande" pathalogie op medisch, fysiek of psychosociaal gebied of van wie de conditie te wensen over laat. In dat laatste geval is meer nodig. (d) Psychosociale groepstraining als aanvulling op lichamelijke conditietraining, teneinde risicofactoren zoals ongezonde leefgewoonten, verwerkingsproblemen, omgaan met stress of overmatige angsten gunstig te beïnvloeden.

(e) Individuele begeleiding door klinisch psycholoog, maatschappelijk werker of diëtist, al naar gelang de noodzaak hiertoe. Ook kan hieronder vallen individuele onispanningstraining (Dixhoorn van, 1991), ongeacht door welke disciplines gegeven.

De gesignaleerde problemen moeten wel verband houden met de hartziekte en de begeleiding moet beperkt blijven in duur en omvang. Indien de verwachting is dat deze vorm van begeleiding langdurig nodig is, of door meerdere disciplines moet worden gegeven, verdient het de voorkeur te kiezen voor revalidatiedagbehandeling of klinische revalidatie.

Patiënten die geen fysiek of psychosociaal programma krijgen kunnen eventueel vrij snel doorverwezen worden voor nazorgactiviteiten. Coördinatie van bovengenoemde programma-onderdelen kan plaats vinden door de cardioloog of revalidatiearts, al dan nief ondersteund door een daartoe opgeleide verpleegkundige. Als een klein ziekenhuis bovengenoemde onderdelen niet in huis heeft, verdient het aanbeveling de patienten naar een ander centrum door te sturen, waar deze mogielijkheden wel bestaan.

(f) Revalidatiedagbehandeling voor mensen die niet geschikt zijn woor bovengenoemde vormen, maar voor wie opname niet nodig is. Het gaat om veelomvattende, intensieve en geindividualiseerde revalidatie, uitgevoerd door een multidisciplinair team waarbij naast conditietraining en groepsprogramma's ook op allerlei individuele problemen kan worden ingegaan.

(g) Klinische revalidatie voor patiënten met ernstige, complexe of multiple problemen na infarct of operatie. Het gaat hierbij om mensen met ernstige medische complicaties ten gevolge van het infarct of operatie, maar ook om mensen met grote psychologische 
problemen. Door deze klinische opvangmogelikheid is de opnameduur in het ziekenhuis vaak belangrijk te bekorten en kan opname in een verpleeghuis worden voorkomem.

Ook mensen met errstige sociale problemen kunnen voor opname in aanmerking komen: een slecht huwelijk, een belastend gezin, moelijkheden met werk, een volstrekt inadequate thuisopvang zoals met name bij de oude operatiepatienten nogal eens het geval is. Deze vorm van revalidatie wordt gegeven door een team dat geheel gespecialiseerd is in hartrevahidatie. Gezien de aantallen patienten die voor deze revalidatievorm in aammerking komen zijn meer klinische revalidatie-afdel ingen nodig dan momenteel aanwezig. Deze afdelingen moeten geografisch goed gespreid zijn.

Tot slot past bij een aanpak waarbij de patiënt centraal staat ook een tinancieringssysteem dat hierop aansluit.

\subsubsection{Nazorg}

Belangrijkste doelstelling van deze fase is het voortzetten van de ingezetle verandering van leefwijze. Op de tweede plaats spelen fysiek en vooral psychosociaal herstel een grote rol en ten slotte blijt de patient doorgaans laagfrekwent onder kontrole bij de specialist.

Activiteiten van patiëntenverenigingen en sportclubs voor hartpatiënten waren aanvankelijk bedoeld om de lacunes in de revalidatie op te vangen (Weeda, 1981). Naarmate het revalidatiepakket completer werd, richtten deze groeperingen zich vooral op nazorgactiviteiten.

Bij nazorg gaat het primair om sportactiviteiten voor ex-patiënten en hun partners. Andere onderdelen van zorg, zoals secundaire preventie en psychosociale zorg, ontbreken meestal (als uitgesproken doel, wel zijn dergelijke doelen vaak impliciet de bedoeling zonder dat men deze heeft geformuleerd). Bij deze activiteiten ligt veel nadruk op eigen iniliatief en verantwoordelijkheid van de (ex-)patiënt zelf.

Welke activiteiten in de nazorgfase effectief cq zinvol zijn, is nog onbekend. Tot op heden is er nog maar een beperkte hoeveelheid onderzoek in deze richting gedaan (Bruggemans ea, 1986; Mortel van de, 1989; Schäperclaus ea, 1991; Frasure-Smith \& Prince, 1985; Friedman ea, 1986). Het is overigens waarschijnlijk dat nazorgactiviteiten bijdragen aan het bestendigen van het korte-termijneffect van revalidatieprogramma's. De gegevens tot dusverte duiden er namelijk op dat de interventies langdurig van aard dienen te zijn (Friedman ea, 1986).

De indicatiestelling voor deze activiteiten ontbreekt. Een systematische advisering door cardioloog en andere teamleden zou zinvol kunnen zijn. Indicatiecriteria zouden dan wel nader gepreciseerd moeten worden. Zo zou iedere patient aan hel einde van de opname of van de revalidatie een advies dienen te krijgen. De overgang vanuit de institutionele gezondheidszorg naar nazorgactiviteiten moet zorgvuldig bewaakt worden. Hier kan de 
huisarts ook een waardevolle rol spelen. Deze dient dan wel op de hoogte te zijn van het voorzieningenpakket in zijn regio.

Het verdient de voorkeur dat er op organisatorisch vlak een landelike en/ol regionale afstemming van activiteiten plaatsvindt, onder meer omdat er in sommige regio's een overlapping aan activiteiten is. Per regio zal er wel een compleet pakket beschikbaar moeten zijn. Mogelijk dat de Hartstichting in samenwerking met de Kruisverenigingen een coördinerende en adwiserende rol zouden kumnen spelen.

De financiering is in principe geen probleem, omdat de activiteiten relatief goedkoop zijn en door de deelnemers zelf betaald worden. In een aantal gevallen is subsidiering mogelijk.

\subsection{HOE VERDER?}

Gesteld kan worden dat dit onderzoek een redelijk compleet beeld opgeleverd heeft van de hartrevalidatie in Nederland. Eveneens is een vergelijking mogelijk gebleken met de stand van zaken in het buitenland. Tot slot zijn de bevindingen afgezet tegen het gevoerde belleid, op grond waarvan aanbevelingen ter verbetering van de revalidatie voor hartpatiënten zijn geformuleerd.

Het is zaak dat de genoemde aanbevelingen omgezet worden in de praktijk. De Nederlandse Hartstichting, de Nederlandse Vereniging voor Cardiologie en andere beroepsverenigingen kunnen hier een belangrijke rol in spelen. Allereerst zal de revalidatie tijdens opname, de revalidatie na ontslag en mel name de overgang tussen deze twee aangepakt dienen te worder. In een later stadium kunnen de nazorgactiviteiten in samenhang met de revalidatie na ontslag ter hand genomen worden.

Een van de belangrikste bevindingen van dit onderzoek is dat er een grote variatie bestaat in indicatiestelling. Het is dan ook zaak dat iedere discipline deze visie uitwerkt op zijh/haar gebied: wat zijn de doelen voor revalidatie, weike programmaonderdelen zijn van belang en hoe dienen ze gedefiniëerd te worden, welke selectiecriteria worden gehanteerd en welke screeningsinstrumenten dienen on wikkeld te worden? Dit dient zowel monodisciplinair als multidisciplinair te gebeuren. De medisch specialisten dienen de medische criteria te formuleren, de klinisch psychologen dienen bouwstenen aan te dragen voor psychosociale indicatiestelling. De klinisch psychologen hebben reeds pogingen hiertoe gedaan (NIP, 1990 en 1992; CBO, 1992; Soons, 1993b). Het is van belang dat bovengenoemd en in de toekonst uitgewerkt model geimplementeerd gaat worden middels enkele proefprojecten in de praktijk. Indicatie-en selectiecriteria dienen gepreciseerd en zonodig bijgestuurd te worden. Per pätient dienen individueel toegesneden doelstellingen geformuleerd en geëffectueerd te worden. Evaluatie-onderzoek dient plaats te vinden om na te gaan bij welke patiënten welk behandelonderdeel effectief is. Op den duur kunnen succesvolle criteria dan door heel Nederland toegepast worden. 
Een tweede belangrijke bevinding is dat de betaling van met name revalidatie-activiteiten na ontslag een probleem is. Dit heeft een ernstig remmende werking in de verdere ontwikkeling. Er is geen tarief voor de cardioloog. Ook is er geen betaling voor het psychosociaal groepsprogramma (inclusief secundaire preventie) en individuele consulten cq medebehandelingen door diëtiste, maatschappelijk werker en klinisch psycholoog. De klinisch psychologen hebben reeds pogingen gedaan hiervoor bouwstenen aan te dragen (Soons, 1992; Soons ea, 1995; Soons, in press) betreffende hun inbreng bij hartpatiënten. Voor deze aspecten dient een tarief gemaakt te worden. Het totaal zou toch butgetneutraal kunnen geschieden (NHS, 1990). Het is zaak de zorgverzekeraars bij deze aanpak te betrekken. 


\section{Samenvatting}

In dit proefschrift wordt een onderzoek beschreven waarin de hartrevalidatie in Nederland is geïnventariseerd. De gegevens, die gerapporteerd worden, zijn verzameld in het kader van "het Registratieproject" van de Revalidatie Commissie van de Nederlandse Hartstichting. De dataverzameling heeft plaatsgevonden van 1987 tot en met 1991.

In hoofdstuk 1 (Inleiding en probleemstelling) worden allereerst de internationale ontwikkelingen op het gebied van de hartrevalidatie beschreven. Begonnen wordt bij de ontwikkelingen van voor 1950 , toen langdurige bedrust voor hartinfarctpatiënten noodzakelijk geacht werd. Door twee ontwikkelingen is dit beleid veranderd. Op de eerste plaats door de toepassing van de "chair treatment" tijdens de herstelfase na een infarct. Op de tweede plaats is de toepassing van de inspanningstolerantie ten behoeve van de inschatting van de arbeidsgeschiktheid na een infarct van belang. Bovenstaande resulteerde in een eenzijdige nadruk op conditietraining in de zestiger en zeventiger jaren. In de jaren hierop volgend is binnen de hartrevalidatie het belang benadrukt van psychosociale factoren. Dankzij het herkennen van risicofactoren voor het krijgen van coronairlijden werd langzamerhand de waarde van secundaire preventie herkend.

Verwolgens wordt ingegaan op de ontwikkelingen in Nederland: deze beginnen bij de oprichting van de Revalidatie Commissie van de Nederiandse Haristichting in 1965. Een jaar later verschijnt een rapport met aanbevelingen over hoe hartrevalidatie in Nederland aan te pakken. In 1970 wordt officieel gestart met hartrevalidatie in 5 centra. Na gunstige ervaringen komt er een financieringsregeling en een erkenningenbeleid voor regionale revalidatie centra, met multidisciplinaire en uitgebreide behandelmogelijkheden. Enige jaren later volgt een financieringsregeling voor afdelingen met alleen fysieke reconditionering. Aangekomen in de tachtiger en negentiger jaren zien we dat nagenoeg het hele land voorzien is met revalidatie faciliteiten, echter er is geen eenduidigheid van organi. satie van de revalidatie. Verder is wel min of meer duidelijk welke onderdelen revalidatie dient te bevatten, maar de indicatiecriteria zijn onvoldoende duidelijk geformuleerd.

Vervolgens wordt ingegaan op de doelstellingen van revalidatie. In hoofdlijnen zijn deze: (a) herstel van functioneren in fysiek, sociaal en psychologisch opzicht en (b) beïnvloeding van cardiovasculaire risicofactoren. Daarna wordt beschreven dat het gehele revalidatietraject opgedee d kan worden in drie fasen, namelijk de opnamefase, de fase aansluitend aan het ontslag uit het ziekenhuis en de nazorgfase elk met hun eigen prioriteiten en doelstellingen. Vervolgens worden de revalidatiegeneeskundige begrip. pen stoornis, beperking en handicap belicht en in relatie gebracht met coronaire hartpatiënten. Tot slot worden de probleemstellingen geformuleerd die in deze dissertatie zullen worden besproken. Hartrevalidatie blijkt zich in de praktijk divers ontwikkeld te hebben door allerlei locale initiatieven. De belangrijkste doelstelling van het onderzoek 
is dan ook geweest om deze verschillen (en overeenkomsten) zo precies mogelijk in kaant te brengen. Welke ontwikkelingen zijn er geweest vanat de start van de revalidatie. Hierbij is ook aandacht besteed aan de ontstane financieringsregelingen. Verder is nagegaan welke soorten instellingen en organisaties zich richten op hartrevalidatie. welke behandelonderdelen er worden gegeven, welke disciplines bij de revalidatie betrokken zijn, wetke patienten met welke kenmerken al dan niet gerevalideerd worden. De cijfers zouden gebruikt kunnen worden om het gevoerde beleid en de concrete gang van zaken te toetsen aan de doelstellingen van revalidatie, revalidatiegeneeskundige opvattingen, beleid van de overheid, en het beleid van de Nederlandse Hartstichting. Tenslotte was van belang te weten hoe de ontwikkelingen in Nederland zich verhouden tot de rest van de wereld.

In hoofdstuk 2 (Literatuuronderzoek) wordt een literatuursurvey uitgevoerd naar inventarisatieprojecten betreffende hartrevalidatie in binnen- en buitenland. Op de eerste plaats wordt nagegaan hoe de stand van zaken van de hartrevalidatie in Nederland en in het buitenland is. Op de tweede plaats wordt geinventariseerd welke methoden er in de diverse onderzoeken zijn gebruikt.

In Nederland blijkt het meeste onderzoek (7 projecten) te zijn verricht van relatief goede kwaliteit. Uit het buitenland zijn in totaal 9 studies bekend die de revalidatie in een land of streek hebben geinventariseend: 3 uit (voormalig) West-Duitsland, 1 uit Engeland, 1 uit Italië, 2 uit de Verenigde Staten, 1 uit Canada en 1 uit Australië. In Nederland wordt de hartrevalidatie in vrijwel alle ziekenhuizen al tijdens opname gestart. In het buitenland is dat lang niet altijd het geval. In de praktijk blijkt hartrevalidatie nagenoeg synoniem te zijn met fysiotherapie.

Hartrevalidatie na ontslag uit het ziekenhuis is veruit de meest onderzochte fase, zowel in binnen-en als buitenland. Ook hier blijkt fysieke training het centrale element te zijn. In een deel varn de instellingen wordt daarnaast al dan niet systematische professionele psychosociale zorg aangeboden. Slechts in weinig instellingen worden systematische therapieën aangeboden gericht op secundaire preventie. Nederland is in verhouding met het butenland actiever op de laatstgenoemde twee onderdelen van revalidatie.

Er zijn in Nederland drie typen afdelingen beschikbaar: aldelingen voor klinische revalidatie, revalidatiedagbehandelingsafdelingen en afdelingen voor fysieke reconditionering. In het buitenland is er over het algemeen veel minder variatie. Tevens is in Nederland een redelijke geografische spreiding van deze faciliteiten, terwijl in het buitenland, behalve West-Duitsland, de faciliteiten geconcentreerd ziln in en rondom de grote steden. Wat betreft de nazorgfase is er onderzoek bekend uit Nederland en West-Duitsland. Ook in deze fase staan de fysieke ca sportactiviteiten centraal. Beide landen zijn ruimschoots voorzien van sportclubs.

Tenslatte wordt in dit hoofdstuk ingegaan op de onderzoeksmethoden. De enquête is de meest gebruikte onderzoeksmethode om data te verzamelen. Deze onderzorksmethode is een geschikt middel am een globaal inzicht te verkrijgen. Niettemin heeft de enquête ook zijn nadelen: er worden in het algemeen retrospectieve gegevens verzameld en de data kumnen subjectief gekleurd zijn, aangezien ze verstrekt worden door de afdelingen zelf. Vandaar dat in het onderzoek van deze dissertatie ook gebruik gemaakt wordt van 
prospectieve gegevenswerzameling, namelik door middel van de individuele patiëntenregistratielijst.

In hoofostuk 3 (Mobilisatie tijdens opname in het ziekenhuis) morden de resultaten beschreven van het onderzoek dat gedaan is naar de revalidatie tijdens de opnamefase Hiertoe is eenmalig een enquête naar 151 ziekenhuizen gestuurd. De respons was slecht $(37 \%)$

Op de tweede plaats werd met behulp van de individuele registratielijsten per patiènt data verzameld in 15 ziekenhuizen, hetgeen gegevens opleverde van 4375 patienten. In totaliteit blijkt dit een waarschijnlijk betrouwbaar beeld op te leveren van de revalidatie tijdens opname. Fysiotherapie werd gegeven in bijna alle ziekenhuizen, aan het merendeel van alle patiënten! De meest betrokken disciplines waren de cardioloog, verpleeg. kundige en fysiotherapeut en in mindere mate maatschappelik werker. De fysiotherapie startte meestal na enkele dagen na de opname. Gemiddeld kregen de patiènten 9 sessies fysiotherapie, één behandeling per dag. $10 \%$ van de patienten haakte voortijdig af met het mobilisatie programma. lets meer dan de helft van alle ziekenhuizen gaf aan een inspanningstest te doen tijdens opname of direct na ontslag. Slechts een kwart van alle patiënten kreeg zo"n test daadwerkelijk. Systematische voorlichting aan patiennten en partners ontbrak nagenoeg geheel. In de meerderheid van de ziekenhuizen bestond de mogelijkheid een maatschappelijk werker of een klinisch psycholoog te consulteren; ook was vaak een diëtiste beschikbaar. Echter in de praktijk werden deze disciplines slechts incidenteel en bovendien meestal op ad hoc basis ingezet.

In vergelijking met Australië, hel enige andere land waarvan cijters over de revalidatie tijdens opname bekend zijn, is in Nederland de revalidatie tijdens opname veel meer verspreid over het land.

In hoofdstuk 4 (Revalidatie na ontslag uit het ziekenhuis) worden de resultaten beschreven van het onderzoek naar revalidatie na ontslag uit het ziekenhuis. In de periode 1986-1989 zijn er jaarijks enquêteformulieren opgestuurd naar alle toentertijd bekende instellingen die een of andere vorm van hartrevalidatie na ontslag gaven. Vrijwel alle instellingen zjin met behulp van de enquête tenminste eenmaal bereikt. Tevens heeft in $1987 / 88$ een mondeling interview plaatsgevonden. Op de derde plaats hebben 15 afdelingen met behulp van de individuele patiëntenregistratielijst ook gegevens verzameld over deze periode, hetgeen in het totaal 2.043 patienten opleverde.

Bovengenoemd onderzoek levert een uitgebreid en betrouwbaar beeld op van de insteilingen in Nederland die hartrevalidatie geven na ontslag uit het ziekenhuis. Hoewel in het buitenland deze revalidatiefase ook onderzocht is door diverse landen, zijn de daar verkregen gegevens beperkt van omvang en slechts beschikbaar van een paar landen; bovendien waren deze onderzoeken gemiddeld veel minder diepgaand.

Nederland kent een diversiteit aan instellingen die hartrevalidatie na ontslag geven: afdelingen voor klinische revalidatie (3 stuks), afdelingen voor revalidatiedagbehandeling (25stuks) en afdelingen voor fysieke reconditionering, met af zonder een beperkt psychosociaal programma (87 stuks). Deze afdelingen bieden, nalast medische zorg. een scala aan behandeimogelijkheden. In alle atdelingen wordt een groepstysiotherapie programma gegeven, dat gemiddeld 3 maanden duurt en gemiddeld 26 sessies omvat; 
in een klein deel van de instellingen bestaat de mogelijkheid voor een individueel aangepast fysiek programma. In de meeste instellingen kan een inspanningstest gedaan worden, waarvan overigens relatief weing gebruik gemaakt wordt. Psychologische vragenlijsten worden weinig toegepast. In tweeviffde van de instellingen wordt een groepsprogramma gegeven, dat gericht is op voorlichting en verandering van risicogedrag; deze programma's zijn echter zeer divers wat betreft aantal sessies, inhoud en deelnemende disciplines. Indivuele consulten want maatschappelijk werker en klinisch psycholoog zijn in de meeste instellingen mogelijk, echter de mate waarin deze disciplines geraadpleegd worden, variëren in hoge mate per instelling. Hetzelfde geldt voor individue le consultatie van de diëtist.

In vergelijking met het buitenland, zijn er in Nederland relatief veel revalidatiefaciliteiten. In principe zijn in Nederland alle typen instellingen en behandelonderdelen aanwezig voor een adekwate aanpak van hartrevalidatie na ontslag. De geografische verdeling en beschikbaarheid van de verschillende revalidatievormen is echter niet geheel optimaal. Daar komt bij dat een gerichte indicatiestelling en dus verwijzing ontbreekt. Herordening en systematische indicatiestelling is noodzakelik, omdat verwijzing naar de verschillende typen revalidatie nu teveel op basis van locale interpretatie plaatsvindt.

Tevens variëert het percentage patiënten dat gerewalideerd wordt sterk van centrum tot centrum. Krijgen patiënten revalidatie dan houdt dat meestal een standaard therapievorm in. Het percentage deelnemers aan de andere behandelvormen variëert in hoge mate. Debet hieraan is dat het doel van revalidatie onvoldoende duidelijk geformuleerd is en de huidige financiële structuur niet adequaat is.

In hoofdstuk 5 (Nazorg) worden de resultaten beschreven van de enquête die in 1990 is gehouden om de nazorgactiviteiten in kaart te brengen. Formulieren werden gestuurd naar alle instanties en patientenverenigingen waarvan bekend was dat ze nazorgactiviteiten gaven aan hartpatienten (203 stuks). Dit leverde een hoge respons op van $91 \%$, hetgeen impliceert dat het onderzoek een betrouwbaar beeld oplevert van de patienteninitiatieven in Nederland.

Er is een diversiteit aan instanties dat nazorgactiviteiten aanbiedt: allereerst zijjn er de trimclubs en patientenverenigingen, die al daru niet onder een regionale of landelike koepel vallen. Op de tweede plaats bieden de Landelijke Vereniging Thuiszorg en de Hartenark groepsvoorlichtingsprogramma:s aan voor (ex)hartpatiènten en hun partners. De trimclubs biedien allerlei soorten recreatiesport aan. De patiëntenverenigingen bieden naast sport ook andere mogelijkheden aan: voorlichtingsgroepen, emotionele ondersteuning door lotgenoten, ontspannings- en vrijetijds activiteiten en tenslotte individuele- en collectieve belangenbehartiging.

De financiering bestaat voomamelijk uit contributie en bijdragen van leden en deelnemers, in een aantal gevallen aangevuld met subsidies van bijvoorbeeld de overheid.

De nazorgactiviteiten blijken nog onvoldoende wasdom te hebben bereikt, hetgeen tot uitdrukking komt in: de ongelijke landelijke verdeling, de sterk wisselende organisatiegraad en het sterk variërende type hulp dat geboden wordt. Sportactiviteiten zijn breed beschikbaar. Zorg gericht op psychosociale problematiek en secundaire preventie zijn zeer beperkt beschikbaar. Sturing en atstemming op organisatorisch niveau is dan ook, 
regionaal en landelijk, zinvol. Ook dient de doorverwijzing naar nazorginitiatieven verbeterd te worden.

West- Duitsland is het enige andere land dat zilin nazorgactiviteiten geinventariseerd heeft. Ook dit land is rum voorzien van trim-en sportgroepen. Van andere nazorgactiveiten is weinig bekend.

In hoofdstuk 6 (Algemene discussie) worden op de eerste plaats de gebruikte onderzoeksmethoden geëvalueerd. Kanttekeningen worden geplaatst bij de methoden wan gegevensvergaring, hetgeen waarschijnlijk een wat rooskleurig beeld heeft opgeleverd. In toekomstig onderzoek zou dit ondermeer ondervangen kunnen worden door ook patienten te betrekken bij de dataverzameling en alle gegevens prospectief te verzamelen. Doordat de gegevens voornamelijk verzameld zijn door een discipline, namelikk de fysiotherapeut, is te verwachten dat er hiaten zifn opgetreden. In de toekomst zou dit ondervangen kunnen worden door het hele team bij de dataverzameling te betrekken.

Op de tweede plaats worden de in dit onderzoek gevonden data kritisch geevvalueerd en besproken. De nadruk ligt op de opnametase en wooral de revalidatie na ontslag uit het zilekenhuis. Fysiotherapie is het meest voorkomende onderdeel van revalidatie. De overige onderdelen, psychasociale zorg en secundaire preventie, worden reatief weinig en weinig systematisch toegepast. Hierbij speelt een belangrijke rol dat er onder professionals onvoldoende overeenstemming is over hoe deze zorg aan te pakken; verder is de financiele structuur niet adekwaat.

Er wordt gepleit voor een selectievere indicatiestelling voor hartrevalidatie: idealiter zou ledere patient tijdens opname of vlak na ontslag gescreened moeten worden, zodat een indiviueel toegesneden revalidatiepakket kan worden samengesteld. De ziekenhuizen dienen een basispakket in huis te hebben: fysieke groepstraining, groeps voorlichtingsprogramma, individuele consultering van diëtiste, maatschappelijk werker en klinisch psycholoog. Voor meer complexe revalidatie kan worden doorverwezen naar een gespecialiseerd centrum, alwaar de patiënt in de vorm van revalidatiedagbehandeling of klinische revalidatie behandeld kan worden. Protessionals dienen dan tot overeenstemming te komen over de indicatiesteling en type zorg. Tevens dient de firanciële structuur aangepast en dus flexibeler te worden. Er worden aanbevelingen gegeven hoe dit in de praktijk budget neutraal gerealiseerd zou kunnen worden. 



\section{Summary}

This thesis describes research into cardiac rehabilitation in the Netherlands. The reported data were gathered between 1987 and 1991 within the framework of "The Registration Project" from the Rehabilitation Committee of the Dutch Heart Association.

Chapter 1 (Introduction and problem definition) begins by describing international developments in cardiac rehabilitation. It starts with developments prior to 1950, a period when long bedrest was considered to be necessary for myocardial infarction patients. This policy was changed by two events: the application of the "chair treatment" during the recovery phase and the use of exercise tolerance testing to assess employment suitability after infarction. These developments resulted in a one-sided emphasis on physical condition training in the sixties and seventies. In later years, the importance of psychosocial factors was emphasized during cardiac rehabilitation. Thanks to the recognition of risk factors that can lead to coronary heart diseases, the value of secundary prevention began to be recognized.

Next, cardiac rehabilitation developments in the Netherlands are described. This began with the foundation of the Rehabilitation Committee of the Dutch Heart Association in 1965. One year later, a report was published with recommendations about how to deal with cardiac rehabilitation in the Netherlands. Cardiac rehabilitation officially started in 1970 in 5 centres. After positive experiences, financial guidelines and license policies were established for regional rehabilitation centres with multi-disciplinary and comprehensive treatment facilities. Some years later, financial guidelines were established for departments who only offered physical reconditioning. During the eighties and nineties, rehabilitation centres were established in nearly all parts of the country. This expansion however, took place without a clear policy on how to organize rehabilitation Although the components needed for rehabilitaion were relatively well known. the indication criteria were not well formulated.

The aims of cardiac rehabilitaion are discussed next. The main aims are: (a) the restoration of physical, social and psychological functioning, and (b) influencing cardiovascular risk factors. There after, the whole revalidation period will be discussed. This period can be divided into three phases: the admission phase, the phase immediately after hospital discharge and finally the maintenance phase, each with their own priorities and aims. Next, the rehabilitation medical terms impairment, disability and handicap are brought into relation with coronary patients. Finally, the problem situation will be formulated which will be discussed in this thesis. In practice, cardiac rehabilitation developed into many directions due to the diversity of local initiatives. The most important aim of this research is therefore to investigate these diversities (and possible similarities) as accurately as possible. What are the developments in rehabilitation and how did financial 
guidelines evolve? An investigation will be made in the type of institutions and organisations involved with rehabilitation, the kind of treatment given, which disciplines are involved with rehabilitation and which patients with which characteristics are being rehabilitated.

This data could be used to test the chosen policy and procedures to see if it meets the aims and medical concepts of rehabilitation and the policies of both the government and the Dutch Heart Association. Finally, it is important to know how the developments in the Netherlands compare to the developments in the rest of the world.

In Chapter 2 (Literature survey) a literature survey is done that lists cardiac rehabilitation projects in the Netherlands and abroad. The state of cardiac rehabilitation in the Netherlands and abroad is investigated first and then the research methods used in the research projects will be listed. The Netherlands appears to have done the most research projects (7) of relatively good quality. Nine studies from abroad are known to have investigated cardiac rehabilitation in a country or district: 3 from (former) West Germany, 1 from England, 1 from Italy. 2 from the United States, 1 from Canada and 1 from Australia.

Cardiac rehabiltation already starts at hospital admission in most hospitals in the Netherlands. This is not always the case abroad. In practice cardiac rehabilitation is almost synonymous with physiotherapy. Cardiac rehabilitation after hospital discharge is the most researched phase in both the Netherlands and abroad. Also here physiotherapy appears to be the central element. Some institutions offer systematic professional psychosocial care and only a few institutions offer systematic therapy based on secundary prevention. Compared to other countries, the Netherlands is most active on the last two mentioned components of rehabilitation.

There are three types of rehabiliation departments in the Netherlands: clinicial rehabilitation, policlinical rehabilitation and physical reconditioning departments. Outside the Netherlands there is in general much less vartation. In the Netherlands, the facilities are relatively well spread geographically whereas abroad, except in (former) West Germany. the facilities are concentrated around the big cities. Research is known in the Netherlands and Germany regarding the maintenance phase. Also in this phase the physical/sports activities are central. Both countries are well provided with sports facilities.

Finally, in this chapter research methods are discussed. The use of questionaires is the most used research method to gather data and is a suitable method to gather a general view. Nevertheless, questionaires have their disadvantages. They are based on data that are collected retrospectively and which could be used subjectively since data are collected by the departments themselves. For this reason, prospective data gathering is also used for this thesis using individual patient registration lists.

In Chapter 3 (Mobilization during haspital admission) the results from research carried out on rehabilitation during the admission phase will be discussed. For this purpose, a one-time questionaire was sent to 151 hospitals. The response from hospitals was limited (37\%). In addition, data from patient registration lists were collected from 15 hospitals which resulted in data from 4375 patients. 
Generally this seems to give reliable information about rehabilitation dunng the admission stage. Physiotherapy was given in nearly all hospitals and to the majority of patients. The closest concerned disciplines were cardiologists, nurses and physiotherapists and to a lesser extent, social workers. Physiotherapy usually started a few days after admission. On average patients received 9 physiotherapy sessions, one per day. About $10 \%$ of patients stopped early with the mobilisation program. Slightly more than half of the hospitals indicated that they gave patients exercise tests during admission or immediately after their discharge. Only a quarter of the patients actually did these exercise tests. Patients and their partners hardly received any secondary prevention. Social workers, clinical psychologists and often a dietician could be consulted in most hospitals, but in most practical cases these disciplines were incidental and usually consulted on an ad hoc basis. Compared to Australia, the only other country with knowm data about rehabilitation during the admission stage, rehabilitation during admission is far more wide spread in the Netherlands.

In Chapter 4 (Rehabilitation after discharge from hospltal), research about rehabilitation after discharge from hospital will be discussed. Questionaires were sent annually to all institutions known to have cardiac rehabilitation after hospital discharge in the period 1986 to 1989. Nearly all the institutions were contacted at least once with the questionaire. Verbal interviews took place in 1987/88. Also in this period, 15 departments collected data from individual patient forms which provided data from 2043 patients.

The above mentioned research produced a reliable picture about cardiac rehabilitation after hospital discharge in Dutch institutions. Although this rehabilitation phase was also investigated abroad, data was usually limited and only available in a few countries. In addition, research was more restricted. The Netherlands know many types of institutions that give cardiac rehabilitation after discharge from hospital: departments for clinical rehabilitation (3), departments for policlinical rehabilitation (25) and departments for physical reconditioning with or without a limited psychosocial programme (87).

These departments offer, besides medical care, many treatment possibilities. In all departments, a group physiotherapy programme lasting three months on average with an average of 26 sessions is given. In some institutions there is a possibility for an individual adapted physiotherapy programme. In most institutions an exercise tolerance test can be done, of which relative little use is made. Psychological questionnaires are used seldomly. In two fifth of the institutions a group programme aimed at providing information and changing riskbehavior is given. These programmes nevertheless are very diverse in the number of sessions, content and participating disciplines. In most hospitals, individual consultations by social workers and clinical psychologists are possible. However, the degree lo which these disciplines are consulted varies much per institution. The same applies for individual consultation by dieticians.

In contrast to other countries, there are relatively many rehabilitation facilities in the Netherlands. In principle the Netherlands has all types of departments and programme components avallable for an adequate approach to cardiac rehabilitation atter discharge. Nervertheless, the geographical distribution and availability of the diverse types of rehabilitation is not wholly optimal. Additionally, an approprate indication and therefore referral is absent. Reshuffling and systematic indication is necessary because referral 
to the diverse types of rehabilitation is now based to much on local interpretation. Also there is a large variation in the percentage of patients who are rehabilitated from centre to centre. Standard therapy is normally used when patients are rehabilitated. The percentage of participants to other treatment components varies to a high degree. This is partly due to the fact that the aim of rehabitation is not clearly formulated and that the present financial structure is not adequate.

In Chapter 5 (After care) the results of the questionnaire which was held to investigate activities in the maintenance phase will be described. Questionnaires were sent to all those resorts and patient organizations known to have after-care activities to ex-patients (203). This resulted in a high response of $91 \%$, which implies that this research produced a reasonably reliable view of patient initiatives in the Netherlands.

There are many kinds of resorts which give after-care activities: firstly there are the sports clubs and patient organizations, which sometimes fall under a regional or national organization. Secondly there are the semi-health care organizations and the Heart Foundation that give secondary prevention programmes for ex-patients and their partners. The sportsclubs affer several kinds of recreational sports. The patient organizathons offer besides sports also other facilities such as: secondary prevention programs, emotional support by fellow-sufferers, relaxation and free-time activities, and finally individual and collective promotion of interests. The financing consist mainly of subscription fee and contribution by members and participants. In some cases they are supplemented by grants from authorities.

The after-care services appear to have reached insufficient growth. This is expressed in the uneven national distribution, the strong varying degree of organization and the strong varying type of help that is offered. Sports activities are widely available. Services for psychosocial problems and secondary prevention are very limited. Regional as well as national guiding and fine-tuning on an organizational level is therefore meaningful. Also referrals to after-care services needs to be improved. (Former) West-Germany is the only other country that has investigated its after-care activities and has many sportsclubs. Little is known about other tacilities in this phase.

In Chaper 6 (General discussion) the research methods that were used, are evaluated. Critical notes are made on the data gathering methods, which probably have produced a somewhat optimistic view. In future research this can be anticipated by also involving patients in data gathering as well as gathering all data prospectively. Since data are mainly gathered by one discipline, namely the physiotherapist, it can be expected that omissions appear. In future, this could be anticipated by involving the whole team in the data gathering process.

Secondly, the data found in this research are critically evaluated and discussed. The emphasis will be on the admission phase and especially on the rehabilitation after hospital discharge. Physiotherapy is the most frequently occurring component of rehabilitation. The other components, psychosocial services and secondary prevention. are applied relatively seldom and not systematically. The fact that there is insufficient consensus among professionals about how this care is set about plays an important role. Also, the financial structure is not adequate. 
A more selective indication for cardiac rehabilitation will be pleaded for: in the ideal situation each patient should be screened during his stay in hospital or immediately after discharge, so that an personally adjusted rehabilitation packages can be composed. The hospitals should provide a basic package: a physical group training, a secondary prevention group program as well as individual consultation by a dietician, social worker and clinical psychologist. For more complex rehabilitation the patient can be referred to a specialized rehabilitation centre, where he can be treated either policlinically of clinically. Professionals should reach consensus on the indication and the type of care. Also the financial structure should be adjusted for more flexibility. There will be given recommendations about how to realize this in practice without additional budget. 



\section{Literatuurlijst}

Appels A (ed). Psychologische risicotactoren woor het hartinfarct. Alphen aan den Alin: Stafleu, 1983.

Aquarius $C$ \& Smit M. Verslag van een inventarisatie van de mogefijkheden van hartrevalidatie in Nederland door middel van een postale enquete. Den Haag: Nederlandse Hartstichting, 1980.

Bangma $\mathrm{BD}$. Revalidatie Geneeskunde: methodologie en praktische vilvoering. PAOG. Rotterdam: Erasmus Universiteit, 1986

Bangma BD. Revalidatie van patiënten met een hartinfarct. Medisch Contact 1987:42:81-84.

Bangma BD \& Kap A. Inleiding rewalidatie geneeskunde: patientgericht hulpverlenen. Assen: Van Gorcum, 1988

Bär FW, Vonken H\& Cluytmans $\rfloor$. Cardiac rehabilitation at the rehabilitation centre "Hoensbroeck". Netherlands Journal of Cardiology 1988:1:27-28.

Bär FWHM \& Vonken HJM. Wat is hel nut van hartrevalidatie? Nederlands Tijdschritt voor Geneeskunde $1990 ; 134: 107-112$.

Bär FW, Höppener P, Diederiks J, Vonken H, Bekkers J, Hoold vd W. Appels A \& Wellens HJJ. Cardiac rehabilitation contributes to the restoration of leisure and social activities after myocardial infarction. Joumal of Cardiopulmonary Rehabilitation 1992:12:117-125.

Begeleidingscommissie Hartchirurgie. Zorg om het hart. Hartchirurgie in de tachtiger jaren. Paming van de behoefte voor 1990 en 1991. Een rapport van de Begeleidingscommissie Hartchirurgie Nedertand aan de Minister en Staalssecretaris van Welzijn, Volksgezandheid en Cultuur. Utrecht. Hartiong Instituut, Academisch Ziekenlhuis Utrecht, 1989.

Bomjer FH. Revalidatie van patienten met hartaandoeningen. Mens en Onderneming 1968;21:342-344.

Btomqvist GG. Use of exercise testing for diagnostic and functional evaluation of patients with arteriosclerolic heart disease. Circulation 1971;64:1120.1136.

Bruggemans E. Elderen T van \& Maes S. Psychosociale effecten van een lange-termijn sportprogramma woor coronaire hantpatienten. Tiburg: Katholieke Universiteit Brabant, 1986.

Cantwell JD. Coronary prevention and rehabihtation in selected countries. In: Pollook ML. Schmidt: DH. Heart disease and rehabilitation. Boston. Houghton Mifflin Prolessional Publishers, 1979.

Centraal Begeleidings Orgaan voor de intercollegiale toetsing. De inbreng van de klinisch psycholoog bij de behandeling wan coronaire hartpatiënten. Utrecht: 1992.

Collins R, Yusut S \& Peto R. Exercise after myacardial intarction reduces mortality: evidence from randomized controlled irails. Joumal of the American College of Cardiologists 1984;3:622-627.

Coronary Prevention Group. Guidelines for setting up and running a cardiac rehabilitation programme. London, 1989. 
Dam $A$ van \& Boer $A$. Ervaringen met een hartrevalidatieprogramma in een samenwerking tussen het $S t$ Radboudzekenthuis en het Revalidatiecentrum St Maartenskliniek te Nijmegen. Nederiands Tijdschrift yoor Geneeskunde 1985:129:1856.

Davidson DM \& DeBusin RF. Prognostic value of a single exercise lest 3 weeks after uncomplicated myocardial infarclion. Circulation 1980:61:236-242.

Davidson C, Green V \& Stanstield B (eds). Cardiac Rehabilitation in the United Kingdom 1985/86. A questionnaire survey. In: Recovering from a heart attack or heart surgery (conterence proceedings). Report of a conterence organised by the Coronary Prevention Group (12ih and 13th october 1988). London. 1988.

Denolin H. Rehabilitation as part of comprehensive care. In: Kallio V \& Cay E (eds). Rehabilitation after myocardial infarction. The european experience. Copenhagen: World Health Organization, 1985.

Diederiks JPM. Herstel en revalidatie na hartinfarct (proefschrift). Maastricht, 1982.

Dixhoom J van, Bär FWHM, Erdman AAM \& Keulen AMA van. Cijfers en beschouwingen over poliklinische hartrevalidatie: een inventarisatie. Hartbulletin 1988;19:11-22.

Dixhoorn $\Downarrow$ wan. Hartrevalidatie: een terugblik. Hartbuletin 1990;21:35-39.

Dixhoorn $J$ van. Relaxation in cardiac rehabilltation. A randomized controlled clinical trial of breathing awareness as a relaxation method in the rehabilitation after myocardial infarction. Fotterdam: Universiteits Drukkerij, 1991.

Editorial. Myocardial infarction then and now. Lancet 1974:1:395-396.

Elderen $T$ van \& Maes $S$. The effects of a psycho-educational group intervention during cardiac rehabilitation. International Joumal of Rehabilitation Research 1988;11:302-303.

Elderen TMT van. Health Education in Cardiac Rehabilitation. Leiden: DSWO Press, 1991.

Erdman RAM. MPVH: Medisch Psychologische Vragenlijst voor Hartpatiënten (handleiding). Lisse: Swets \& Zeitlinger, 1982.

Erdman RAM \& Dixhoorn J van. Verslag van het derde wereldcongres over hartrevalidatie, Caracas, october 1985. Hartbulletin 1987;18:18-20.

Erdman AAM \& Weeda HWH, Vierde wereldcongres hartrevalidatie, Broadbeach, Australië, october 1988. Harbulletin 1989; 20:78-81.

Fioreti P. Simoons ML, Zwiers G, Baardman T, Brower RW, Kazemir M \& Hugenholtz PG. Vallie of predischarge data for the prediction of exercise capacily atter cardiac rehabilitation in patients with recent myocardial intarction. European Heart Journal, 1987; 3 supplement G.33-38.

Fiorell P. Baardman T, Brower AW \& Hugenholtz PG. Hemodynamic measurements during the acute phase of myocardial infarction: implications for prognosis and cardiac rehabilitation. Journal of Cardiopulmonary Rehabilitation 1988;8 265-269.

Federatie van Nederlandse Verenigingen voor Voor- en Nazorg bij Hartziekten. Adressengids. Zoetemeer 1990.

Frasure-Smith $N$ \& Prince $R$. The ischemic heart disease lifestress monitoring program: impact on mortality. Psychosomatic Medicine 1985:47:431-444.

Fredman $M$. Thoresen CE, Gill JJ, Ulmer D, Powell LH. Price VA, Brown B, Thompson L, Rabin DD, Breall WS, Bourg E, Leyy $R$ \& Dixon T. Alteration of type A behavior and its effect on cardiac recurrences in post myocardial infarction patients: summary results of the recurrent coronary prevention project. American Heart Journal 1986;112:653-665. 
Froelicher VF. Batter A \& Mckinnan MD. The use of exercise testing to evaluate patients in cerdiac rehabilitation. In: Pollock ML\& Schmidt DH. Heart disease and rehabilitation, Boston: Houghton Mifflin Professional Publishers, 1979.

Gentry WD \& Williams RB (eds). Psychological aspects of myocardial infarction and coronary care. Sain Louis: The C.W. Mosby Company, 1975.

Giordano A. Lo stato della riabilitaizione del cardiopatico in lialia. Gionale Italiano di Cardiologia 1989

Gleichmann U. Mannebach H \& Halhuber C. Die aktuelle Situation in den ambutanten Koronanguppen der Bundesrepublik Deutschland: Ergebnisse einer bundesweiten Umfrage. Zeitschrift ur Kardiologie $1983 ; 72: 418-425$

Gosselink IKJM. Hartrevalidatie, een kostenstudie. Doctoraal-scriptie Faculteit der Gezondheidswetenschappen. Maastricht: Rijksuniversiteit Limburg, 1989

Green V, Stansfield B. \& Davidson C. Cardiac Rehabilitation in the United Kingdom 1985/86. A questionnaire survey. Physiotherapy 1988 (august).

Groden BM. Semple T \& Shaw GB. Cardiac Rehabiftation in Britain 1970. British Heart Joumal $1971 ; 33: 756-758$.

Guitker de Geus S. Klinische fysiotherapie bij hartpatiënten. Nederlands Tijdschrift voor Fysiotherapie 1988:98:264-267.

Harrison TA. Abuse of rest as a therapeutic measure for patients with cardiowascular disease. JAMA 1944:125:1075 1077.

Hellerstein HK. Cardiac rehabilitation: a retrospective wiew. In: Pollock ML. \& Schmidt DH (eds). Heartdisease and rehabilitation. New York: J. Willey, 1986.

Hart In Beweging. De oprichting van een recreatie-sportgroep voor (ex)hartpatienten: wie, wat, waar, hove. Bilthoven, 1989(a).

Hart In Beweging. Beleidsplan 1989. Bithoven, 1989(b).

Hillebrand A \& Vermeulen A. Ervaringen met begeleiden van bejaarde hartpatienten na de acute lase. Nederlands Tijdschrift voor Geneeskunde 1981:125:1869-1873.

Jetté Ms Landry F \& Blumchen G. Cardiac Rehabilitation in the Federal Republic of Germany: Klinik Roderbirker. Journal of Cardiopulmonary Rehabiltation 1988;9:341-349.

Kazemier M. Capri Rotterdam: cardiologische revalidatie in groepsverband. Hartbulletin 1979;10:6.

Kein Nulens GJ, Nauta ILD. Saxena PA \& Weel C wan. Het Cardiovasculair Formularium 1991: Een praktische leiddraad. Rotterdam: Phamad Publishing, 1991.

König $K$ \& Denolin $H$ (eds). Psychological problems in cardiac rehabilitation. Zurich: Council on Rehabilitation of the International Sociely of Cardiology, 1976.

Koninklijk Nederlands Genootschap voor Fysiotherapie. Briel dd 20 juni 1990.

Kromme de-van der Kilis /L. Psychosociale factoren rondom hartinfarct. Cordiaal 1982:3.59-62.

Leeuwen M van, Gercama J \& Sorber H. Gespreksbijeenkomsten voor hartpatiènten. Verslag Landelijk Project Hartgroepen. Bunnik: Nationale Kruisverenigingen. 1986. 
Levine SA \& Lown B. The "chair" treatment of acute coronary thrombosis. Trans Association of Amencan Philsicians $195: 64316-327$.

Lindvall $K$, Ehardi LP, Lundman T, Rehnqvist N \& Sjogren A. Early mobilization and discharge ol patients with acute myocardial intarction: a prospective study using risk indicators and early exercise tests. Acta Medica Scandinavia 1979;206:169-175.

Landelijk Medische Registratie/Stiching Informatie Gezondheidszorg. Jaarboek ziekenhuizen 1988. Uirech, 1989.

Lorsheyd JJG. Enkele kengetallen van algemene en academische ziekenhuizen 1989 (nr. 90.475 . Utrecht: National Ziekenhuis Instituut: 1990.

Maeland JG \& Havik OE. The effects of an in hospital educational programme for myocardial infarction patients. Scandinavian Jourmal of Rehabilitation Medicine 1987;19:57 465 .

Maes S, Foreest $M$ van, Smulders $M$, Elderen $T$ van \& Bruggemans $E$. Voorlichting aan coronaire haripatienten. Tilburg: Kaholieke Universiteit Brabant, 1986.

Maes Si, Elderen $T$ van \& Bruggemans $E$. Effecten van voorlichting aan coronaire hartpatienten. Gezondheid en Samenleving 1987:8:60-76.

Maes S\& Elderen T wan. Effects of psycho-educational programmes in cardiac rehabilitation. Netherlands Journal of Cardiology 1988; 1:30-35.

Mallory GK. White PD \& Salcedo-Salger J. The speed of healing of myocardial infarction: a study of the pathological anatomy in seventy-two cases. American Heart Joumal 1939:18:647-671.

Meegdes JG. De revaliclatiefunctie in revalidatiecentra en ziekenhuizen: vraag- en aanbod. patientenstromen, regionalisatie. Utrecht: Nationaal Ziekenhuis Instituut, 1988.

Messin R \& Demaret B. Accelerated versus classical early mobilization after myocardial infarction. Advances in Cardiology 1982;31:152-155.

Meyer GC. Cardiovascullar rehabilitation: a discipline in need of a new direction? (Editorial). Journal of Cardiopulmonary Rehabilitation 1985:5:507-509.

Meijburg-Schutte JM \& Meijler FL. Tweedelijns cardiale zorg. Na onderzoek van revalidatieperiode in buitenkliniek. Hartbulletin 1975;6:2-8.

Mejler FL. Revalidatie na hartintarct. Nederlands Tijdschrift voor Geneeskunde 1973;117:1234-1236.

Miller DH \& Borer JS. Exercise testing early after myocardial infarction: risks and benefits. The American Jounal of Medicine 1982:72:427-438.

Miller HS, Ribis PM. Adams GE \& Boone W Th. Communify programs of cardiac rehabilitation. In: ML Pollock \& DH Schmidt. Heart disease and rehabilitation. Boston: Houghton Miftin Professional Publishers, 1979.

Mortel PMM van de. Vooronderzoek naar de effecten van Meer Bewegen voor Hárt-Vaalpatiënten (doctoraalscriptie). Maastricht: Rijksuniversiteit Limburg, 1989.

Nederlandse Hartstichting. Revalidatie van hartpatiënten. Den Haag, 1966.

Nederlandse Hartstichting. Revalidatie van hartpatiënten in Zweden en Finland: verslag van een studiereis voor de Nederlandse Hartstichting. Ants \& Verzekering 1969.

Mederlandse Hartstichting. Fievalidatie van hartpatiënten. Den Haag, 1977.

Nederlandse Hartstichting. Hartrevalidatie.. mée dan nodig. Den Haag, 1984. 
Nederlandse Hiartstichting. Hantrevalidatie op maat: nieuwe visies. Den Haag, 1990.

Nederlands Instituut van Psychologen. De inbreng van de klinisch psycholoog in de hartrevalidatie. Verslag van de Commissie Hartrevalidatie, ingesteld door de sectie Psychologen Algemene Ziekenhuizen wan thet Nederlands Instituut van Psychologen. Amsterdam. 1990.

Nederiands linstituut van Psychologen. De inbreng van de klinisch psycholoog bij de behandeling van coronaire hartpatiënten. Voorbereidings werkgroep ingesteld door de sectie Psychologen Algemene Ziekenhuizen. Amsterdam, 1992.

Nederlandse Vereniging woor Fysiotherapie bij Hartpatiënten. Klinische fysiotherapia bij hartpatiënten. Utrecht, 1988.

Nationaal Ziekenhuis Instituut. Productiestatistiek. Algemene Ziekenhuizen 1988 (nr 89.661 ). Utrecht, 1989 .

Nationaal Ziekenhuis Instituut. De intramurale gezondheidszorg in cijfers per 1 januari 1989 (nr 90.671 ). Utrecht, 1990.

O'Connor GT. Buring JE, Yusul S, Goldhaber SZ, Olmstead EM, Paffenberger AS \& Hemekens CH. An overview of randomized trials of rehabilitation with exercise after myocardial infartion. Circulation $1989 ; 80,234-244$

Oldridge NB, Guyatt GH, Fischer ME. Cardiac rehabilitation after myocardial infarction. Combined experience of randomized clinical trials. JAMA 1988;260, 945-50.

Pryor DB, Hindman MC, Wagner GS, Califf RM, Rhoads MK \& Rosati RA. Early discharge after aculle myacardial infarction. Annals of Internal Medicine. 1983;99:528-538.

Provinciaal Steunpunt Bewegingsactiviteiten Gezondheidszorg. Meer bewegen voor hart en vaatpatiënten. Sittard: 1988.

Provinciaal Steunpunt Bewegingsactiviteiten Gezondheidszorg. Presentatie PSBG. Sittard 1991.

Rooy C de \& Cornel F. Provinciale ontmoeting hart- en vaatziekten. Sittard: Steunpumt Zellzorg Initiatieven, 1988

Rooymans HGM. Herkenning en behandeling van stoornissen bif verwerking vän oen hartinfarct. Hartbulletin 1979:10:3 5.

Royal College of Physicians/British Cardiac Society. Cardiac Rehabilitation 1975. Report of a Joint Working Party of the Royall College of Physicians of London and the British Cardiac Society. Journal of the Royal College of Physicians of London, 1975:9:281-346.

Schäperclaus GA, Greef de MHG \& Rispens P. Secundaire preventie. Over de arganisatie van sportgroepen woor (ex) hartpatienten (SVH) en de inwloed op risicofactoren vour coronaire hartziekten in Nederland en Duitsland. Groningen: Rijksuniversiteil Groningen, Werkgroep Bewegingswetenschappen, Noordelik Centrum voor Gezondheidsvraagstukken, 1991.

Segew $U$ \& Schlesinger $Z$. Rehabilitation of patients after acute myocardiall intarction; an interdisciplinary, family-ariented program. Heart Lung 1981:10:841-847.

Senten MCM. Cardiologische nazorg in Nederland: een overzicht in ciffers (submitted for publication).

Soons PHGM. De gedragstherapeutische behandeling van een hartrevalidant. $N=1$ studie ter werkrijging van het lidmaatschap van de Vereniging voor Gedragstherapie. Nijmegen: St. Maartenskliniek, 1989 
Soons PHGM, Bar FWHM \& Mulleneers R. Registreren: waarom en hoe? Fysiovisie, 1989:9-11.

Soons PHGM \& Bär FWHM. Revalidatie van hartpatienten tijdens opname en na ontslag uit het ziekenhuis: cifer en trends. Nederiands Tijdschrift voor Geneeskunde. 1990,134:103-106(a).

Soons PHGM \& Bä FWHM. The present state of cardiac rehabilitation in the Netherlands. in: Proceedings of the 5 th Europearis Aegional Conterence of Rehabilitation International, Dublin/lreland, may 20/25. $1990(\mathrm{~b})$.

Soons PHGM \& Erdman RAM. Coronaire hanpatienten. In JMH de Moor, HGG wan Balen, KA Beers \& LAJ de Vos. Revalidalie psychologie. Assen: Van Gorcum, 1990.

Soons PHOM. Organisatie en financiering. In NIP, De inbreng van de klinisch psycholoog bij de behandeling wan coronaire hartpatienten. De woorbereidingswerkgroep ingesteld door de sectie psychologen algemene ziekenhuizen van het NP. Arnsterdam: NIP, 1992.

Soons PHGM. Hartrevalidatie. In TS Bierma (Red.) Verslag Sudiedag Hartrevalidatie 16 october 1992 in Kasteel Vaalsbroek. Hoensbroek: Lucas-Stichting voor Revalidatie, 1993(a).

Soons PHGM. Consensus: hulp of keursilif? In J. Hendriksen, H. Jurjens \& K Beers (Red.) Kwaliteit van zorg. Najaars-conlerentie 1992, sectie Revalidatiepsychologen. Amsterdam: NIP, 1993(b).

Soons PHGM, Groen M. Jeuken J. \& Swaak-Beuken YJM. Het systeem van klinisch psychologische verrichtingen: een plannings-instrument. Eindvarslag Commissie Verrichtingen ingesteld door de PAZ. Amsterdam: NIP, 1995.

Soons PHGM. De psycholoog in de hart-thuis-zorg (in press).

Southard DA \& Broyden R. Psychosocial services in cardiac rehabilitation: a status report. Journal of Cardiopulmonary Rehabilitation 1990;10.255-263.

Spaan JM \& Speld GDJ van der. Ziekenhuizen in cijfers (nr. 90.670). Utrecht: Nationaal Ziekenhuis Instituiut, 1990.

Stocksmeier $U$ (ed). Psychological approach to the rehabilitation of coronary patients. International Society of Cardiology, Scientific Council on Rehabilitation of cardiac patients. Berlin: Springer Verlag, 1976.

Stocksmeier U. Erfahrungsbericht bei der Grundung von Coronar-Clubs an Kramkenhäusern. Therapiewoche 1978;28: 5382-5384.

Stratten $\Downarrow$ wan. Revalidatie van de hartpatient. Samenwalting van hef rapport uitgebracht door de Nederlandse Hartstichting. Mens an Onderneming 1968:21:345-354.

Superko HA. Wood PD \& Haskell WL. Coronary heart disease and risk factor modification. The American Journal of Medicine 1985;78:826-838.

Therroux JP. Waters DD. Halphen C. Debaiseux JC \& Mizgala HF. Prognostic value of exercise testing soon after myocardial infarction. New England Joumal of Medicine 1979:301: 341-345.

TNO Internationale Classificatie van stoornissen, beperkingen en handicaps. WHO - Voorburg: Raad voor Gezondheidsresearch TNO, 1981.

Uden MMAT van, Erdman RAM, Zoeteweij MW, Verhage $F_{*}$ Vermeulen A \& Weeda HWH. Heeft hartrevalidatie effect? Een literatuurstudie. Gedrag \& Gezondheid 1986;14:153-158.

Uniken Venema-Uden van MMAT. Hartrevalidatie: over het bepalen en voorspellen van herstel (proefschift). Utrecht, 1990. 
Verkley H \& Voontham A. Hartrevalidatie in ontwikkeling. Gezondheid en Samenleving 1982;2:24.34.

Vermeulen A. Rehabilitation afier myocardialintarction (proefschrifth. Universiteil ven Amsterdam, 1983.

Verstappen HMCh, Pol JMJ van der \& Nivelle HMF de. Enkele ervaringen bil revalidatie van patienten met een myocardinfiarct. Nederlands Tijdschrit voor Gerneeskunde 1974:118:716-721.

Vlek JFM. Buntink F. Crebolder HFJM \& Ree van IW. De rol van de huisarts bij de begeleiding van patiënten na een myocardintarct. Nederlands Tijdschrift voor Geneeskunde 1994:138:2049-2053.

Vos R. De verstrekking revalidatie-dagbehandeling. Den Haag: Geneeskundige hoofdinspectie aldeling verkeersongevallen, ambulancewervoer en revalidatie, 1978

Vries J de. Nederlandse Vereniging van Artsen voor Revalidatie en Physische Geneeskunde Vergadering gehouden op 26-27 october 1984 te Heerlen. Nederlands Tijdschrift woor Geneaskunde 1985;129:1852-1856.

Waters DD. Bosch X, Bouchard A, Moise A. Roy D. Pelletier G \& Theroux P. Comparison of clinical variables and variables derived from a limited predischarge exercise test as predictors of early and late mortality after myocardial infarction. Journal of the American College of Cardiologists $1985 ; 5: 1,8$.

Waters DD. Exercise lesting after myocardial infarction: a perspective. Journal of the American College of Cardiologists 1986;8:1007-1017(a).

Waters DD. Exercise testing after myocardial infarction: a perspective. Journal of the American College of Cardiologists $1986 ; 8: 1018-1019(\mathrm{~b})$.

Weeda HWH \& Visser JF. Revalidatie van hartpatiènten anno 1981. Hartbulletin, 1981;12:3-7.

Weeda HWH. Revalidatie en secundaire preventie; een gelukkige combinatie? Hartbulletin $1981 ; 12: 15-16$.

Weeda HWH. Revalidatie wan hartpatiënten. In: Dunning AJ, Meijler FL \& Verheugl APM (eds). Nederlands Leerboek der Cardiologie. Utrecht: Bohn, Scheltema \& Holkema, 1983

Weiner DA, Ryan TJ, McCabe CH \& Chaitman BR. The role of exercise testing in idientifying patients with improved survival after coronary artery bypass surgery. Journal of the American College of Cardiologists 1986; 8:741-748(a).

Weiner DA. Role of exercise testing after myocardial infarction. Joumal of the American College of Cardiologists $1986 ; 8 ; 1020-1021(b)$.

Wenger NK. Panel II: the pros and cons of early mobilization and of the convalescent phase in rehabilitation. Bibliotheca Cardiologica 1977;36:45-49

Wenger NK. Rehabilitation of the patient with acute myocardiall infarction: early ambulation and patient education. In: Pollock ML \& Schmidt DH (eds). Heart disease and rehabilitation, Boston: Houghton Mifflin Professional Publishers, 1979.

Wenger NK, Hellersiein HK, Blackburn H \& Castranova SJ. Physician practice in the management of patients with uncomplicated myocardial infarction: changes in the past decade. Circulation $1982 ; 65: 421-427$.

Wenger NK. Early ambulation: the physiological basis revisited. Advances in Cardiology $1982: 31: 138 \cdot 141$

Wenger NK. Early ambulation after myocardial infarction: rational, program components and results, In: Wenger NK. Hellersteirs HK, eds. Rehabilitation of the coronary patient. 2nd ed. New York: John Wiley, 1984.

Wenger NK. Future directions in cardiovascular rehabilitation (Editorial). Jounal of Cardiopulmonary Rehabilitation 1987:7:168:174. 
Wast RR \& Henderson AH. Randomised mulicentre trial of early mobilization after uncomplicated myocardial intarction. British Hearl Joumal 1979;42:381-385.

World Health Organization. Rehabilitation of patients with cardiovascular diseases. Report of the WHO expert committee. Geneva, 1964.

World Health Organization. The rehabilitation of patients with cardiowascular diseases. Report on a Sieminar: Noordwijk aan Zee 2-7 october. Copenhagen, 1967 .

World Health Organization. A programme for the physicall rehabilitation of patients with acute myocardial infarction. Prepared by a working group. Freiburg-im-Breisgau, 1968.

World Heath Organizaltion. WHO-repon on Rehabilltation. Geneve, 1969.

World Health Organization. Psychological aspects of the rehabilitation of cardiovascular patients. Report on a working group: Warsaw 28-30 may 1969. Copenihagen, 1970.

World Health Organization. WHO Research Group. Exercise tests in the assessment of cardiovascular function. Hartbulletin 1972;3:45-51.

Wiklund I, Sanne $H$, Vedin A \& Wihelmsson Cl. Determinants of retum to work one year after a first myocardial infarctionn. Journal af Cardiopulmonary Rehabilitation 1985;5:62-72.

Wilson PK. Edgett JW \& Porter GH. Rehabilitation of the cardiac patient: program organization. In: Pollock ML., Schmidt DH. Heart disease and rehabilitation, Boston: Houghton Mifflin Professional Publishers, 1979.

Wolfe LA, Herbert WG, Miller J \& Miller DS. Status of cardiovascular rehabilitation in Virginia. Journal of Cardiopulmonary Rehabilitation 1987;7,42-50.

Wolfe LA, Dafoe WA, Hendren-Roberge EA \& Goodman LS. Cardiowascular Rehabilitation in Ontario (Canada). Joumal of Cardiovascular Rehabilitation 1990;10:130-140.

Worcester M. Cardiac rehabilitation programmes in Australian hospitals. National Heart Foundation of Australia, 1986.

Ziekentondsraad. Advies inzake hel besluit inzake revalidaliedagbehandeling ziekenfondswerzekering. Amstuveen, 1981.

Ziekenfondsraad. Feconditionerende fysiotherapie (ontwerp). Amstelveen, 1985.

Ziekentondsraad. Flapport van de werkgroep revalidatie aan de commissie verstrekkingen van de Ziekentondstaad inzake herstructurering van de verstrekking van revalidatie dagbehandeling. Amstelveen, 1989. 
BIJLAGE I

Enquête hartrevalidatie tijdens opname 


\section{nederlandse haristichting}

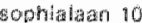

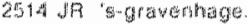

vrienden vari de hartstichting

telofour 070-92 4292 .

posteing 300

(indan bovenstadnde gegevens onjuise garne correctel

MARTREVACOATIE TIODNS OPNAME 1988

Toe engute over revalidatie tijdens opname is nieum dit jaar, die over revalidatie ma ontsiag is bijgevoegd en is nagenoeg hetzelde als an 1987 )

Doet un irstelling an hartrevalidatie bijoens opname?

0 jat

0 nee

DEEL I: MANTALLEN PATIENTEN

(imaten geen exacte cijfers bekend garme sohatting)

Patienten arotallen tijdens opname

Hanteert u een expliciete leeftjosgrens: ....

Pationten in 1988

(aratal)

miangen

Houwen

jomger dan 50 jaar

wusen 50 en 70 gatar: ...

70 fant an ouder: ....

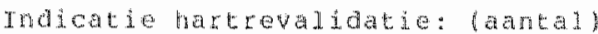

hartinfarct $\quad \ldots$ prea

coromare bypass .... klepoperatie...

Ap/dragerd inaret.... overige, nl ... 


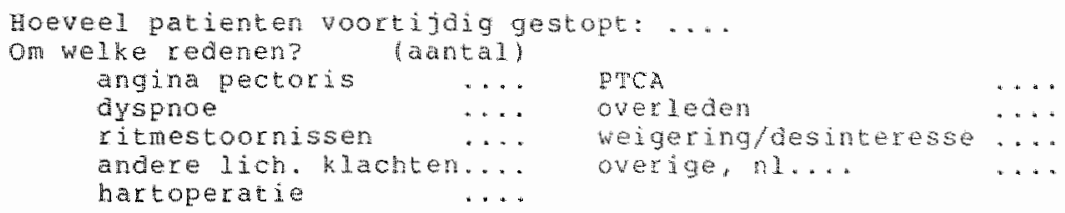

\section{Psychosociale begeleiding}

(alieen zorg door matschappelijk werk "psycholoog, andragoog en psychiater is bedoeid)

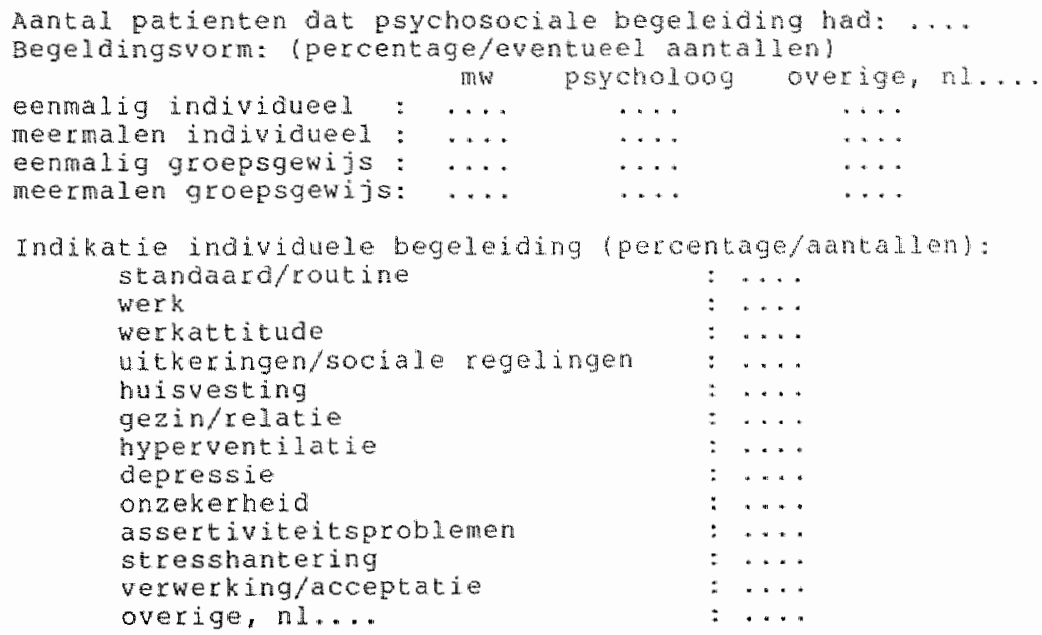

\section{Revalidatie na ontslag}

Hoeveel patierten komen na ontsiag terug in un insteling voor revalidatie: .... (a) (antal)

De patienter are niet terugkomen:

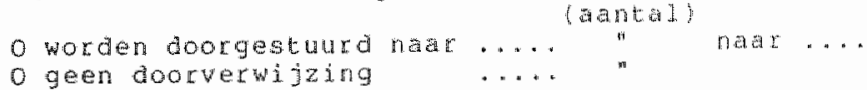




\section{DEEL II: ALGEMEHE GEGEVEMS}

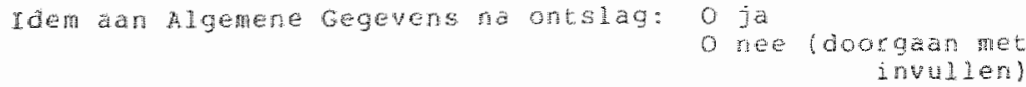

\section{Agenene gegevens}

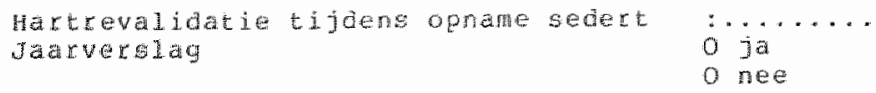

\section{Detrokken disciplines}

\begin{tabular}{|c|c|c|}
\hline cardioloog & 0 & $\begin{array}{l}\text { Op af } \\
\text { a anberig }\end{array}$ \\
\hline interniet & 0 & $\begin{array}{l}\text { OQ a } \\
\text { andowe }\end{array}$ \\
\hline artseval datiearts & 0 & $\begin{array}{l}\text { og afroep } \\
\text { andezig }\end{array}$ \\
\hline fysatherapeut $(\mathrm{en})$ & 0 & $\begin{array}{l}\text { op a roep } \\
\text { annezig }\end{array}$ \\
\hline matschappelijk werk & 0 & 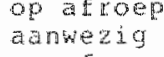 \\
\hline psycholoog & 0 & $\begin{array}{l}\text { op a Eoep } \\
\text { andezig }\end{array}$ \\
\hline oliefste & $\begin{array}{l}0 \\
0\end{array}$ & $\begin{array}{l}\text { op af coep } \\
\text { a a moter }\end{array}$ \\
\hline vergleegkndige & 0 & 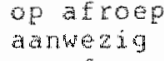 \\
\hline administratief medewerker & $\begin{array}{l}0 \\
0\end{array}$ & $\begin{array}{l}\text { op afroep } \\
\text { aanwezig }\end{array}$ \\
\hline overige, si .... & $\begin{array}{l}0 \\
0\end{array}$ & $\begin{array}{l}\text { ap afroep } \\
\text { anwezig }\end{array}$ \\
\hline
\end{tabular}

Het team overlege .... keer o per meek o per mandid

Besproken werd: o patientenvortgang

o geen expliciet teamover jeg

o beleidsaspekter

o overige, nl...

worat er een administratie bijgehouden vam patienten: 0 ja

zo ja, o in en boek of klapper

o hee

O 1 n de status

O via Individuele patiantendijot hartsticheing

o overige, mi....

Welk teanid houdt administratis bij ...

Welke testerocedures werden toegepast:

obrdial amderzoek

pychosocidal intervisu anvang afsiuting op ind. pgychologische vragendijoten overige, nl....

ergometrie: submaximar maximant vorm van ergometrie

$\begin{array}{lll}0 & 0 & 0 \\ 0 & 0 & 0 \\ 0 & 0 & 0 \\ 0 & 0 & 0 \\ 0 & 0 & 0 \\ 0 & 0 & 0\end{array}$


Eysiefe programa tijaens opname

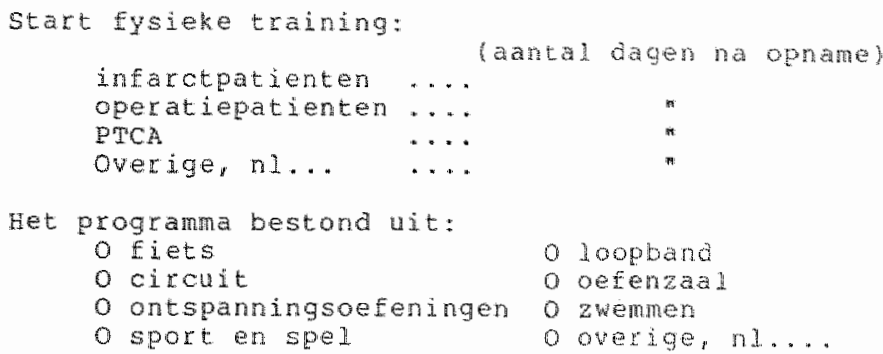

\section{Voor 1 ichting}

Voorlichtingsaktivitedten ajin: o onderdeel fysiek programa a a art georgantseer

Vorm varilionting:

O individued.

o groepsgek ijs

Voovichting over:
o informatie over operatie
o somatische aspektan
o informatie over infarct
o psychosociale aspekten
o risikofaktoren
o revalidatie na ontslag
o vaeding
o overige, nl...

Welke aisciplines gaven voorichting:
o cardioloog
o rewal idatie ates
o psycholoog
o Eysiotherapeut
o matschappelijk werker
djetiste
o verpleegkundige
o overige

\section{Psychosociale begeleiding tijdens oprame}

Gebruikte methoden door:

Crisisinterventie

Ondetsteunend kontakt

ontspanningstherapie

vorm van psychotherapie

te weten...

Groepswerk

overige, ni... nw psycholoog overige, in $1 .$.

$\begin{array}{ll}0 & 0 \\ 0 & 0 \\ 0 & 0 \\ 0 & 0 \\ 0 & 0 \\ 0 & 0\end{array}$

OPMERKIHGEN: 

BIJLAGE ॥

Individuele patiëntenregistratielijst hartrevalidatie tijdens opname en hartrevalidatie na ontslag uit het ziekenhuis 


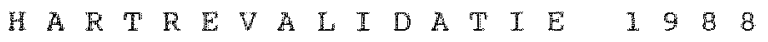

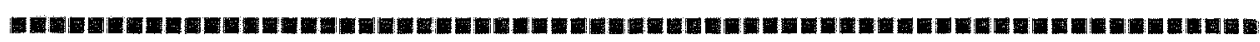

NAMM :

GEBOREN : 1

GESLACHI: [ ] (1=

STRAAT : I

I PIATS $:$

VERZEKERING: [ ]

$(1=$ ziekentonds, $2=$ particuliex, $3=$ anders, $0=$ onbekend $)$

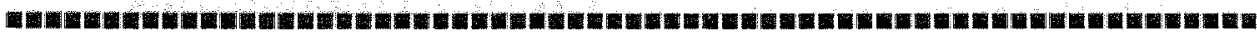

IWDICATIE REVAIIDATIE: [ ]

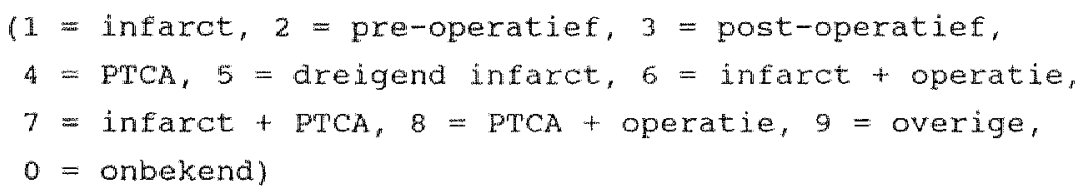

INDIEN OVERIGE: [

NYHA KLASSE AP: [ ] NYHA KLASSE DYSPNOE: [ ]

( 1 = geen ap of dyspnoe, $2=$ bij zwardere inspanning,

3 = bij lichte inspanning, 4 = in rust, $0=$ onbekend

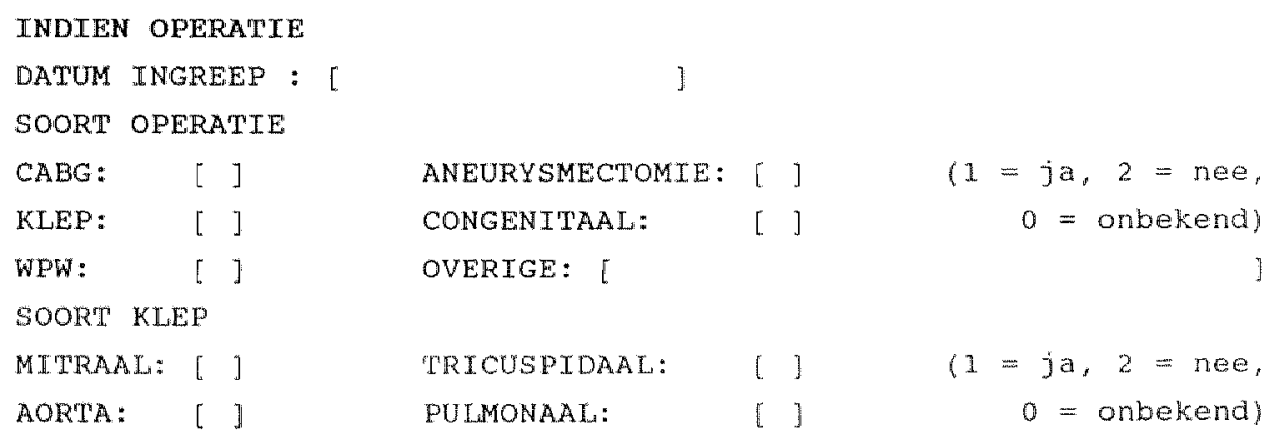

INDIEN INFARCT

DATUM INFARCT:

MAXIMALE SGOT: [ ] U/L

TROMBOLITICA: [ ]

$1=j a, 2=$ nee,

RECANALTSATIE: [ ]

$0=$ anbekend)

GROOTTE INFARCT: [ ] (1=klein, 2 =middel, 3 =groot, 0 =onbekend)

BEHANDELEND CARDIOLOOG/INTERNIST: 『 
CARDIAAL

HARTINFARCT

GELEIDINGSSTOORNISSEN

POMPFUNKMTESTOORNISSEN

OVERIGE $(1=j a, 2=n e e, \quad 0=$ onbekend $)$ ANGINA PECPORIS : [ ] RITMESTOORNTSSEN : [ ] REANIMATE $:[1$

NIET-CARDIAAL

LONGPROBLEMEN

$(1=$ nee, $2=$ CARA 3 atelectase, $4=$ pnemonie,

5 = overige, $0=$ onbekend)

NEUROLOGISCHE PROBLEMEN : [ ]

( $1=$ nee, $2=$ CVA, $3=\operatorname{TIA}, 4=$ overige, $0=$ onbekend $)$

$\begin{array}{ll}\text { BEWEGINGSPEBERKINGEN } & :[\mathrm{l}] \quad(1=j \mathrm{a}, 2=\text { nee, } 0=\text { onbekend }) \\ \text { CIAUDICATIO } & :[] \\ \text { OVERIGE COMPLICATIES } & :[\end{array}$

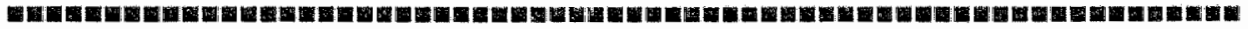

P S Y C H O S O C I A L E S I T U A T I E

ARBEIDSSITUATIE : [ ] (1-werk, $2=$ WAO, $3=$ AOW, $4=$ WW, $5=$ huisvrouw, $0=$ onbekend)

(EX) BEROEP :

SOCIALE PROBLEMEN : [ ] ( $]=j a, 2=$ nee, $0=$ onbekend $)$

PSYCHISCHE PROBLEMEN : [ ]

BIJZONDERHEDEN : [ 


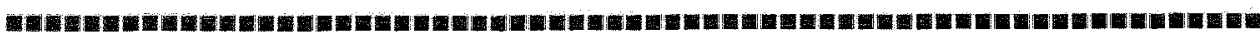

G E G E

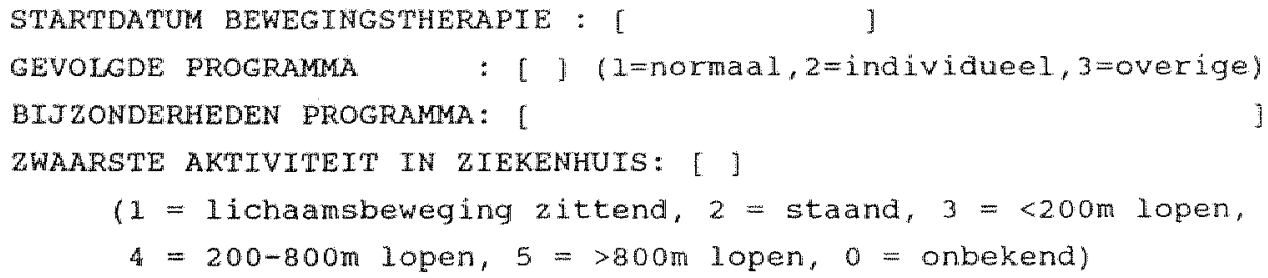

$(1=$ normal, $2=$ vertraagd, $3=$ moet afgeremd worden, $4=$ moet gestimuleerd worden, 5 = overige, 0 = onbekend)

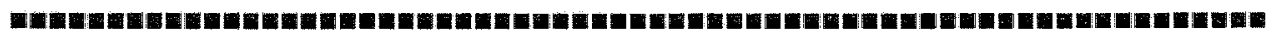

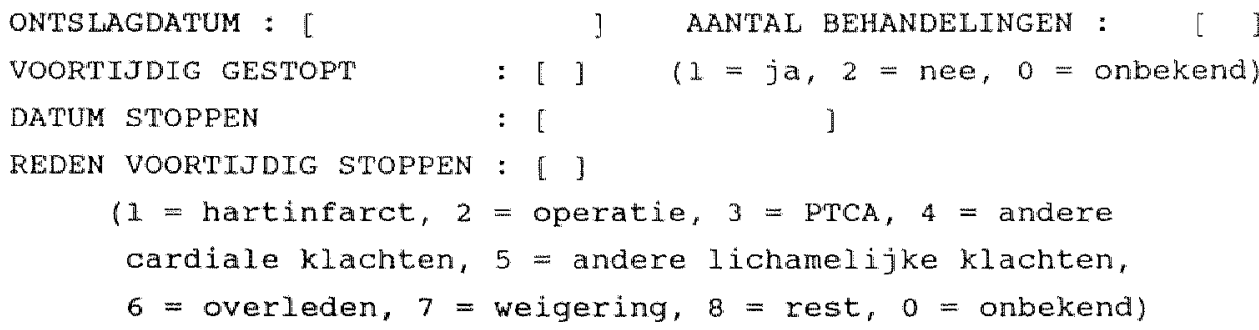


I N S P A N N I G S O N D ER Z O E K

(TIJDENS OPNAME OF IE NA ONTSLAG)

INSPANNINGSONDERZOEK VERRICHT : [ ] ( $1=j \mathrm{a}, 2=$ nee, $0=$ onbekend $)$

HOOGST BERETKTE STADTUM : [ ]

$(1=$ Bruce $I=\leq 75$ Watt, $2=$ Bruce II $=\leq 120$ Watt.

$3=$ Bruce III $=\leq 160$ Watt, $4=$ Bruce IV $=\leq 230$ watt,

$5=$ Bruce $V=>230$ Watt, $0=$ onbekend)

PIJN OP DE BORST, TYPISCH VOOR ANGINA PECTORIS : [ ]

$(1=j \mathrm{a}, 2$ nee, 0 = onbekend )

REDEN STAKEN : [ ]

$(1$ = angina pectoris, 2 = dyspnoe, 3 =vermoeidheid,

$4=$ pijn in benen, $5=$ collaps/duizeligheid, $6=$ ritme-

stoornissen, 7 = ECG-afwijkingen, 8 = bereikte polsfrequen-

tie, $9=$ andere, $0=$ onbekend)

POLSFREQUENTIE

BEGIN: [ ]/min MAXIMAAL: [ $J /$ min NA RUST: [ ]/min

CONCLUSIE CORONARIALIJDEN : [ ]

$(1$ = onwarachijnlijk, 2 = onzeker, 3 = suggestief,

4 = waarschijnlijk ernstig, $0=$ onbekend)

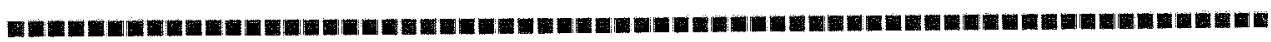

VOORTZETTEN POLIKLINISCHE REVALIDATIE IN : $[$ ]

$(1=$ eigen $z$ iekenhuis, 2 = ander ziekenhuis, $3=$ revalidatiecentrum, $4=$ fysiotherapie in periferie, $5=$ geen voortzetting, 6 = anders, $0=$ onbekend) 


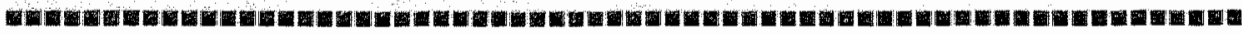

POLIKLINISGHE G E G E V E N S

ONTSLAGDATUM UTT ZIEKENHUIS : [ ]

REEDS REVALTDATIE TIJDENS OPNAME : [ ] ( $1=j$ a , $2=$ nee, $0=$ onbekend) STARTDATUM POLIKIINISCHE FYSIEKE PROGRAMMA : [

OP VERWIJZTHG WAN : [ ]

$11=$ eigen ziekenhuis, 2 = ander ziekenhuis, $3=$ huisarts,

$4=$ rest, $0=$ onbekend

CONDITIE VOOR POLIKLINISCHE REVALIDATIE : [ ]

$(1=$ goed, 2 = matig, $3=$ slecht, $0=$ onbekend $)$

GEVOLGDE POLIKLINISCH FYSIEKE PROGRAMMA : [ ]

$(1=$ normal, 2 = indiwidueel, 3 = overige, $4=$ geen)

OVERIGE PROGRAMMA : [

GEVOLGDE PSYCHOSOCIALE PROGRAMMA : [ ]

$(1=$ normal, 2 = indiwidueel, 3 = geen $)$

DOOR : [ ]

( $1=$ psycholoog, $2=$ matsch, werker, $3=$ overige, $0=$ onbekend) VOORMAAMSTE REDEN :" [ ]

( 1 = werk, 2 = angst, 3 = relaties, 4 = routine, 5 = overige $)$ CONTACT DIETISTE : [ ]

$(1=$ nee, 2 = routine, 3 = specifieke indicatie, $4=$ overige, $0=$ onbekend)

DEELNAME PARTKER AAN PROGRAMMA : [ ] ( $1=j \mathrm{j}, 2=$ nee, o=onbekend)

- DEELNAME PARTNER FYSIEK PROGRAMMA : [ ]

- DEELNAME PARTNER GROEPSGESPREKKEN : \&

- DEELNAME PARTMER VOORLICHTINGSBIJEENKOMSTEN : [ ]

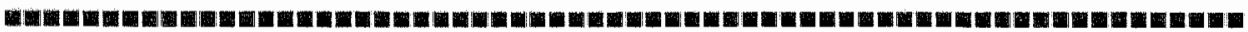

BIJZONDERHEDEN TIJDENS POLIKLINTSCHE REVALIDATIE * 
EINDRESULTAAT FYSTERE PROGRAMMA : [ ]

$(1=$ volledig programma, 2 = beperkt programa, $3=$ voor tijdig gestopt)

REDEN STOPPEN : [ ]

11 = hartinfarct, 2 = operatie, $3=$ PrcA, $4=$ andere cardiale klachten, $5=$ andere fysieke klachten, $6=$ overleden, 7 = weigering, 8 = overige)

EINDDATUM BEWEGINGSTHERAPIE: [

] AANTAL THERAPTEDAGEN: [ ] INDRUK VAN HERSTEL : [ ]

$1=$ normaal, 2 =vertraagd, 3 moet afgeremd worden,

$4=$ moet gestimuleerd worden)

TOESTAND NA FYSIEKE PROGRAMMA : d ] (1=goed, 2=matig, 3=slecht) PSYCHISCHE PROBLEMEN : [ ] ( $1=j \mathrm{a}, 2=$ nee, $0=$ onbekend $)$ SOCTALE PROBLEMEN $:[]$

EVENTUELE PSYCHOSOCIALE PROBLEMEN : WERKHERVATTING : [ ] $(1=j \mathrm{a}, 2=$ partiee $1,3=$ nee $)$ REDEN PARTIEEL OF STOPPEN WERKEN: [ ]

$(1=$ ziektewet, 2 = afkeuring, 3 =overige, $0=$ onbekend $)$ HUISHOUDELIJK WERK HERWAT : [ ] NORMALE ACTIVITEITEN HERVAT : [ ] ADVIEZEN NA ONTSLAG

11 sportgroep, 2 = fietsen, 3 = ontspanningstherapie, $4=$ zwemmen, 5 = Hartenark, 6 = overigel

VERWEZEN VOOR VERDERE BEGELEIDING NAAR : [ ] [ ]

$1=$ huisarts, $2=$ psycholoog, $3=$ dietiste, $4=$ psyonia ter, 5 = RIAGG, 6 = matsch. werk, 7 = overige)

CONTROLE NA ONTSLAG DOOR: [ ]

$(1=$ cardioloog, 2 = internist, 3 = huisarts, 4 = overige $)$ 

BIJLAGE III

Enquête hartrevalidatie na ontslag uit het ziekenhuis 


\section{nederlandse hartstichting}

sophalatarn 10,

2514 IA "s "gratambe

vrienden van de hartstichting

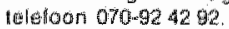

posigira 300 .

(indien boverstande gegevens onjuist garne corectie)

GARTREYALIDATTE NA ONTSLAG 1989

DEEL 1: AANTALLIEN PATIENTEN

Tindien geen exacte cijers bekend, gadre schat ingen)

\section{Algemene gegevens}

Aantal patienten in 1988: ...

Hanteert $U$ een expliciete leeftijdsgrens: ....

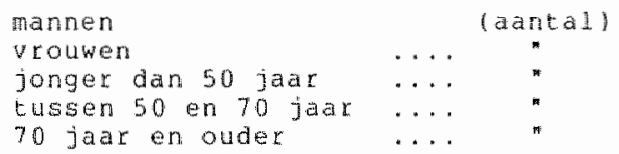

Verwezen door: 0 agen ziekenhuis

o andere ziekenhuizen

o operige, ni....

.... percentage)

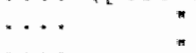

Indicate hartrewalidatie: taantali
bartinf at
...
$\mathrm{P} \mathrm{P}^{\prime} \mathrm{CA}$
caronatre bypass....
klepoperatie....
hatarelgend intarc
overige,nl

Hoevel patienten voort jojg met revalidatie gestopt: .... on welk rederen? fantal)

\begin{tabular}{|c|c|c|c|}
\hline angina pectords & $\cdots$ & PTCA & $\ldots$ \\
\hline dysproe & $\ldots$ & overteden & $\ldots$ \\
\hline ritmestoornissen & $\cdots$ & weigering/desinteresse & $=$ \\
\hline $\begin{array}{l}\text { andere lich. klachten } \\
\text { hat operatie }\end{array}$ & & overge, n1... & $\cdots$ \\
\hline
\end{tabular}

Psychosociale begeleiding

(a)len zorg door matschappeijk werk, psycholoog, andragoog en psychiater is bedoeld; terugkomur en voorlichting tellen niet meey 
Aartal patienten dat psychosoclale begeleiding had: .... Begeleidingsvorm:

(percentage/annallen)

\begin{tabular}{|c|c|c|c|}
\hline & psychosoge & maatsch werk & ov a n $\mathrm{n}$. \\
\hline eenmalig individueel: & $\ldots \ldots$ & $\ldots$ & $\ldots$ \\
\hline meermalem individued: & $\ldots$. & $\ldots$ & $\ldots$ \\
\hline eemalig groepsgewijs: & $\ldots$ & $\ldots$ & $\ldots$ \\
\hline meermalen groepsgewijs: & $\ldots$ & $\ldots$ & $\ldots$ \\
\hline
\end{tabular}

Indikatie individuele begeleidig(percentage/antallen):

standaard/xoutine : ....

werk $\quad: \ldots$

werkattitude : ...

uitkeringen/sociale regelingen: ....

huisuesting

gezin/relatie $\quad: \ldots .$.

hyperventillatie :

depressie ; ....

onzekerheid : :...

assertiviteitsproblemen : $\quad \ldots$.

stresshantering : ....

verwerking/acceptatie : ....

overige, nI.... : ...

verwijzing voor verdere psychosociale begeleiding nadr:

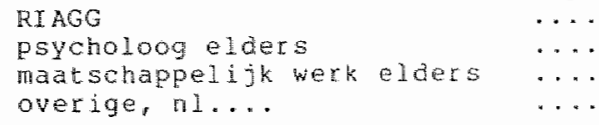

DEEL TI: ALGEHENE GEGEVENS

i nderstaande gegevens zijn geheel of gedeelteli jk bekeri ut voorafgande jaren. Indien er onjuistheden of a anvulingen ajju ten opzichte van de lijst uit 1987 garne

\section{Algemene gegevens}

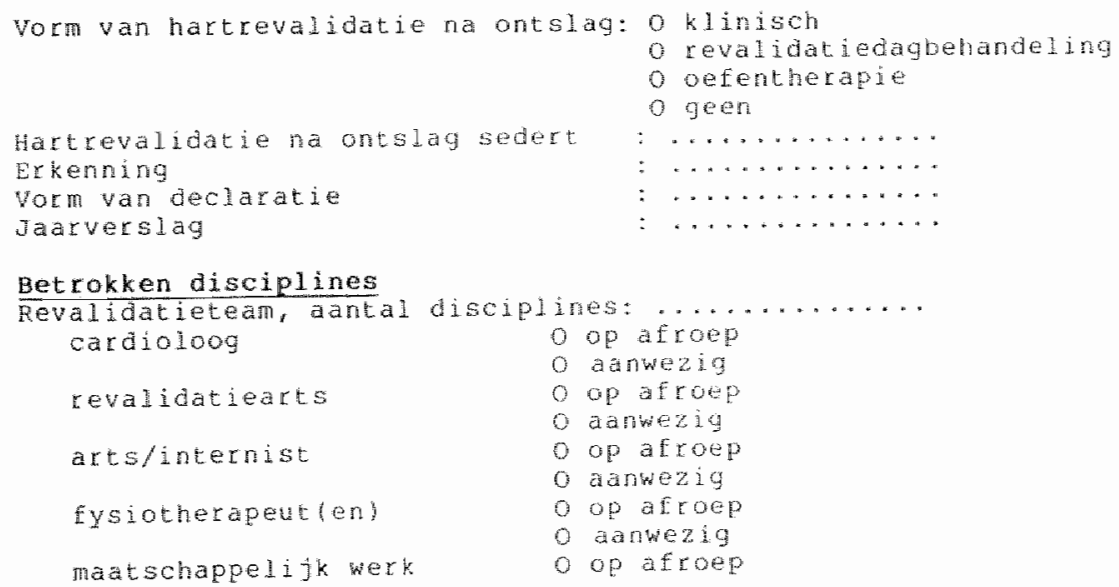




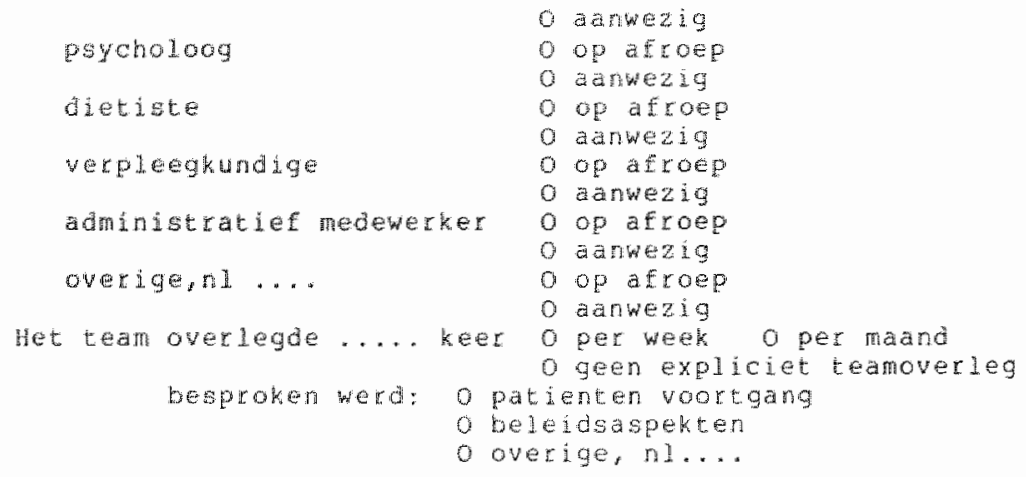

Wordt er een administratie bijgehouden van patienten: 0 ja

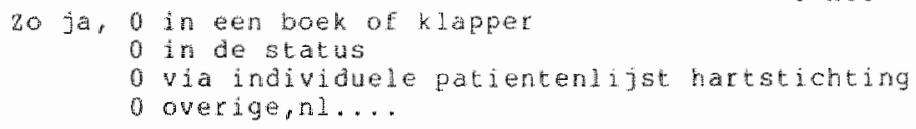

Welk teamid houdt dezen administratie bij:....

Wie onderhoudt contact met GAK/CMD/BOD:

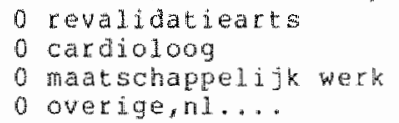

Wat doet 4 a 15 een patient niet kont:
0 niets
Q patient bellen
0 cardiolocg imichter o huisarts indichten
o overige, nj....

Aktieve deelname partners a programba 0 ja 0 nee

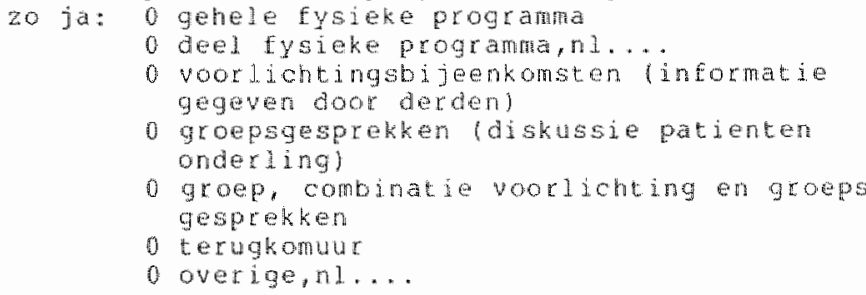

welke tegtprocedures werden toegepast:

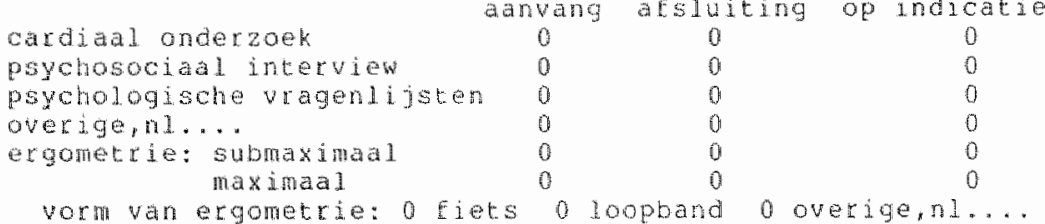




\section{Eysieke progitama}

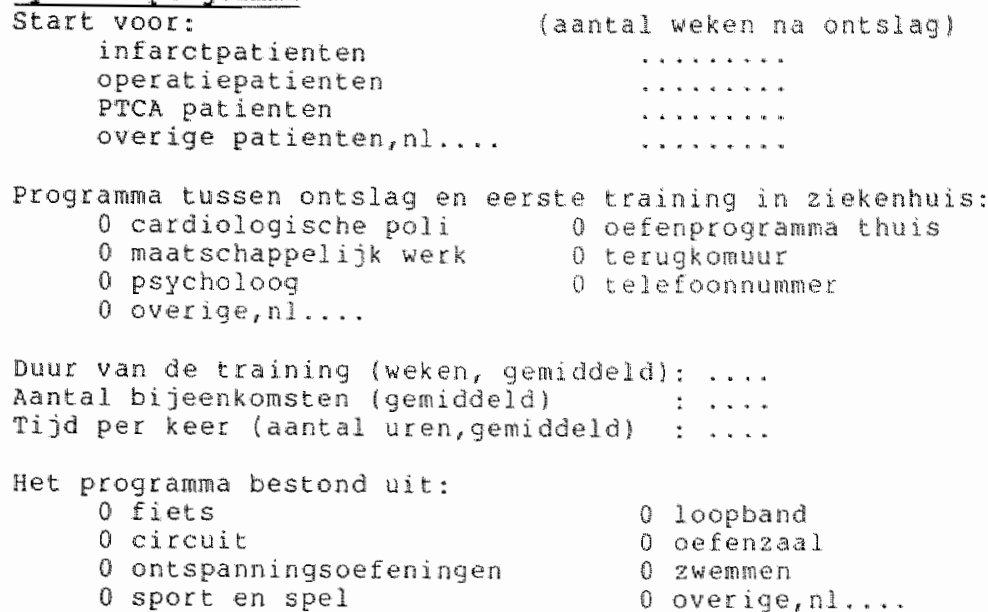

Het advies na de traning bestond uit:

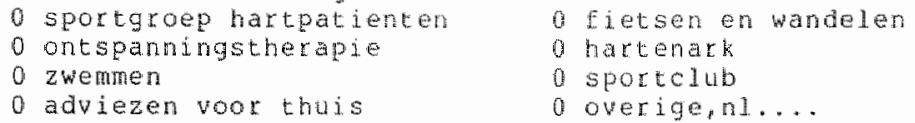

\section{Voorlichting}

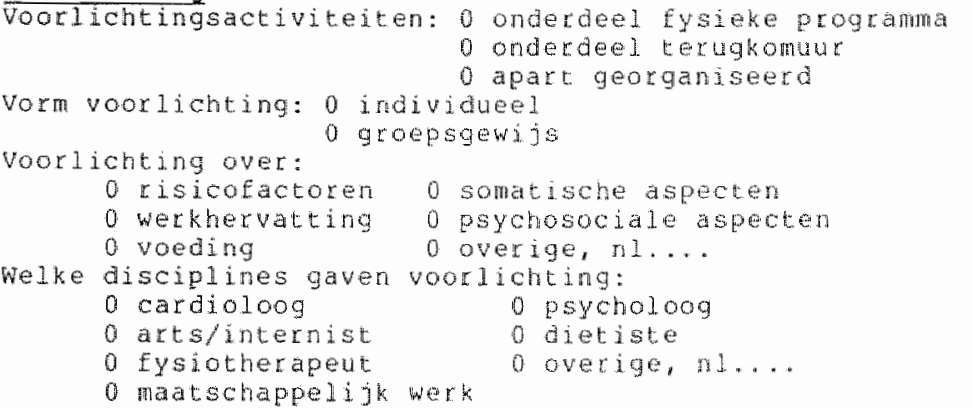

\section{Psychosociale zorg}

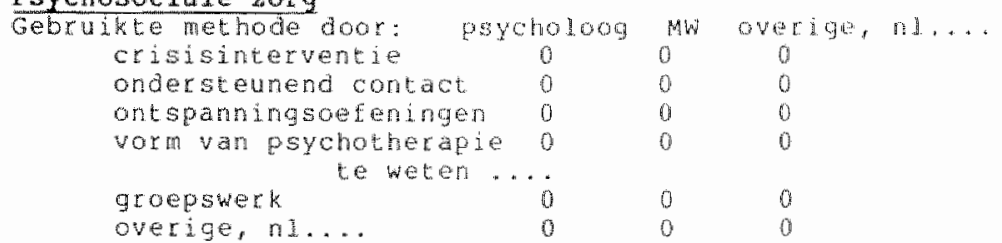

OPMERKINGEN 

BIJLAGE IV

Enquête nazorg hartpatiënten 


\section{nedertaredse hartstichting}

sophtaldan 10

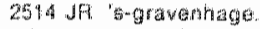

vrienden van de hartstichting

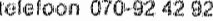

posigino 300 .

\section{ENQUELE HAORG HARTPATIENTEN IN NEDEQLAWD}

(zonodig bovenstande gegevens aunpassen)

\section{Organiatio}

Thieronder verstaan wij stichtingen, werenigingen. instellingen etc die activiteiten voor (ex-jhartpatienten organaseren

Wancer is Uw organisatie gestart met zijn activitaiden? .... ( $j$ artal invadien)

Voor welke werkgebied?

O lande lijk

o prowincasal. nl....

oredionat. nl....

o platatselijk, nl....

Is Uw organiati angsioten bil een overkoepelend organ?

o ja. landelijk, te weten:.....

provincial. te weten: ....

(n)

andersi. ni:....

Welke "ijn de financiele bromen van bw oxgandatie?

0 collectes/inzame lactios

odonatios/lidmatschapsgelden

o irkamsen uit activiteiten

0 industre sponsoring

o subsidie van overheid

o subsiaties van stichtingen

o zanders. $n l: \ldots .$. 


\title{
nederlandse harlstichting
}

Soptlyialatan 10 ,

2514 dir 's-gravemhage

telefoall oro-92 4292

postoiro 300

vrienden van de hartstichting

\author{
zijn deze bromnen voldoende voor het organiseren van Uh \\ activiteiten? \\ o ja

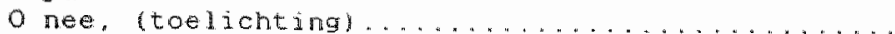

\section{Patienten Lloden}

Wie kumen er lid worden wan w organisatie?

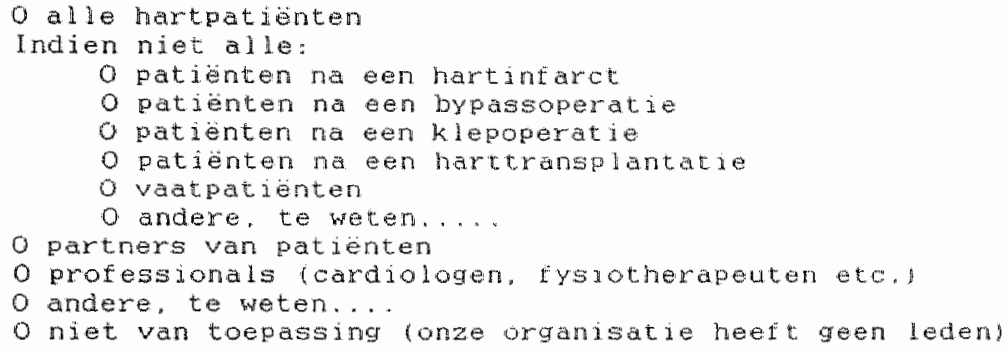

Hoeveel lederidonateurg heeft Uw organisatio?.....

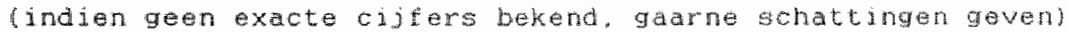

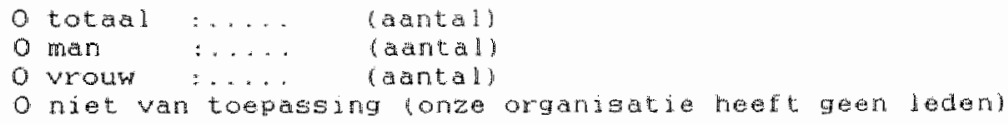

op weik tijdstjp na ontslag uit het ziekentuis worden pationtem toegelaten tot Uw activiteiten?
O na operatio
$\therefore \ldots$
(aantal weken ra ontslag)
o na infarct
$\therefore \ldots$
( . . . . . . .

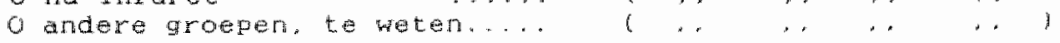




\section{nederlandse harkstichting}

gophühtak 10 .

2514 .JP. 'D-graverthate

vrienden van de hartstichting

tol

positgito 200

Op welke doelgropen zijn Uh activitelon gericht?

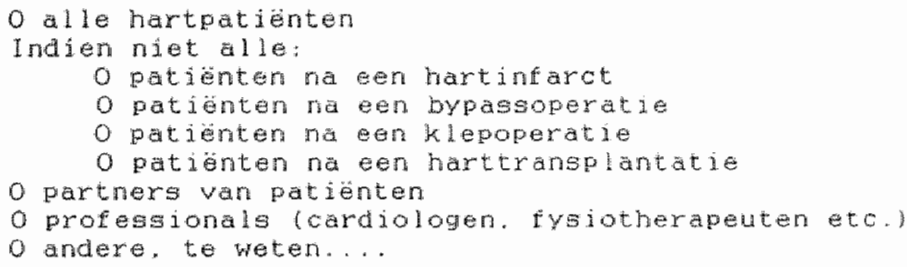

III Activitejten en antal deolnemers

(indien geen exacte cijfers bekend, gatrne schattingen goven)

Welke activiteiten werden door u georganiseerd en hovel mensen hebben daram dee igenomen in 1989 ?

0 individuele voorlichting an ex-patienten

o voorlichtingagroepen voor patjenten

o voorlichting aan gezondheidszorg instellingen ....

O gespreksgroepen cq hulgkmergroepen

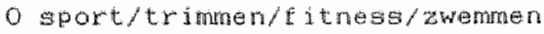

o sportagen

o ontspanning/vrije tija

o individuele psychosociale begeleiding

0 individuele balangenbehartiging

o collectieve belingenbehartiging

0 Klachten behande I ing

o het udtgeven van en verenigingsblad

o andere, to meteri...

0 andere, te wetan...

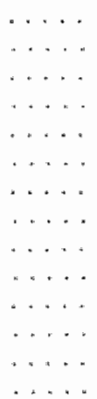

Wia verarom de activitejten?

ivrijullligers/ex-patienten/professionals/anderen 


\section{nederlandse hartstichting}

Sophialaan 10

vrienden van de hartstichting

2514 JR. 's-grawerhage

teletoon 070-92 4292

pastgira 300.

\section{opmerkingen:}

lmier kunnen onderwerpen a an bod komen die in het voomatgande niet zijn genoemd en die nax Uw inzicht wel van belang zijn!

\section{Slotvraag:}

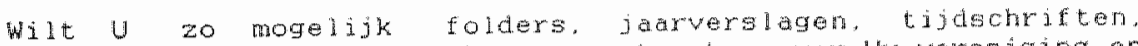
mededelingenbladen (lactse numer) etc over uw vereniging en activiteiten meesturen? 



\section{Dankwoord}

Aan de tot standkoming van deze dissertatie hebben velen bijgedragen.

Het registratieproject op basis waarvan deze dissertatie tot stand is gekomen, is een project dat gesubsidieerd is door de Nederlandse Hartstichting. Jan van Dixhoorn heeft veel voorwerk gedaan, hij was projectaanvrager en wij hebben ruimschoots gebruikgemaakt van zijn know-how en adviezen. Marion Verhulsdonk dient genoemd te worden omdat zij mij getipt heeft voor de vacature van dit project.

Frits Bär was projectleider en heeft deze rol op een voortvarende, stimulerende en creatieve manier vormgegeven. Zijn aanpak van praktijkgericht onderzoek en zijn inzet om de resultaten hiervan aan te wenden ter verbetering van de kwaliteit van de patiëntenzorg, hebben mij altijd erg aangesproken. Door onze samenwerking heeft het project zowel in binnen-als buitenland ruimschoots in de belangstelling gestaan. Hij is ook degene geweest die, met nimmer aflatend geduld, de verschillende hoofdstukken van dit proefschrift tot in hun ruwe vorm begeleid heeft.

Dank ook aan Mitzi Bär niet alleen vanwege haar uitstekende gastvrijheid tijdens de besprekingen in de avonduren, maar ook voor de invoer van data in de computer.

Vervolgens is Jos Diederiks erbij betrokken. Door zijn kritische en altijd constructieve houding werd de ruwe diamant fijngeslepen en goed genoeg geacht om aan de promotor voor te leggen.

Prof. Wellens heeft op zijn beurt de puntjes op de i gezet en het manuscript goedgekeurd. I $k$ vind het een grote eer dat hij zich bereid heeft verklaard als promotor van dit proefschrift op te willen treden.

Ik heb dankbaar gebruik gemaakt van de opmerkingen en adviezen van de beoorde. lingscommissie. Door hun bijdrage is de kwaliteit van de uiteindelijke versie van dit proefschrift verbeterd.

Voor de verhoging van de leesbaarheid van hoofdstuk 2 tot en met 5 dank aan mijn zwager Frans van Dijk. Voor de correctie van de drukproeven dank aan Mia van Dijk. Viola Janssen en Birgit van der Burg. Voor de bijdrage aan de vertaling van de samenvatting wil ik bedanken Rob en Ina Zeitlin.

Voor de thulp bij de dataverzameling ben ik dank verschuldigd aan de Nederlandse Vereniging voor Fysiotherapie bij Hartpatiënten, de ziekenhuizen, de teams en aan de vertegenwoordigers van de patiëntenverenigingen en hun koepelorganisaties. Speciale dank aan Emile Thijssen voor zijn gegevens van sportgroepen. Zonder hun inzet zou dit onderzoek niet hebben kunnen plaatswinden. Dank ook aan de instellingen die de 
individuele patientenregistratielijsten gebruikt hebben. De Nederlandse Hartstichting dient hier genoemd te worden vanwege het beschikbaar stellen van computers ten behoeve van de dataverzameling.

Rob Mulleneers, Berto Bieijlevens en Jan Heymeriks van de Afdeling Cardiologie ben ik dank verschuldigd voor hun programmeerwerk en adviezen op automatiseringsgebied. Voor administratieve en overige ondersteuning dank aan de verschillende secretaressen van de Aídeling Cardiologie, waarbij Margriet Muytjens speciaal genoemd dient te worden. Tevens dank aan het St. Annaziekenhuis voor de ondersteuning; genoemd dienen te worden oa de directie en de afdeling automatisering.

Tenslotte wil ik dit proefschrift opdragen aan mijn familie: op de eerste plaats ter nagedachtenis aan mijn moeder die vorig jaar helaas te vroeg overleden is en die zich erg verheugd had op deze dag en aan mijn vader. Verder aan Mia, mijn echtgenote en aan onze kinderen Rutger, Jeroen en Astrid, die samen met mij blij zijn dat deze anderneming afgerond is. 


\section{Curriculum Vitae}

Paul Soons werd op 18 juli 1956 geboren te Merkelbeek (L.). In 1975 deed hij eindexamen Gymnasium A aan het Bisschoppelijk College te Sittard. Vervolgens ging hij aan de Kathoileke Universiteit Nijmegen psychologie en filosofie studeren, alwaar hij in 1980 in beide studies het kandidaatsexamen heeft afgerond. In 1984 studeerde hij af in de psychologie met als hoofdrichting klinische psychologie, als nevenrichting arbeids- en organisatiepsychologie en als bijvak economie voor psychologen.

Daarna volgden part-time aanstellingen voor wetenschappelijk onderzoek aan de Vak groep Klinische Psychologie van het Psychologisch Laboratorium van de KUN (1984. 1986) en aan de Vakgroep Cardiologie van de Medische Faculteit van de RL te Maastricht (1987-1991). In Maastricht heeft hij gewerkt aan het Registratieproject van de Revalidatie Commissie van de Nederlandse Hartstichting, op basis waarvan dit proefschrift tot stand is gekomen. Hij was tevens secretaris van de taskforce die het rapport "Hartrevalidatie op maat: nieuwe visies" voortbracht.

Naast het wetenschappelijk onderzoek is hij steeds part-time werkzaam geweest in de patiëntenzorg achtereenvolgens aan het Ambulatorium van het Psychologisch Laboratorium (KUN) (1984-1987), de St. Maartenskliniek te Nijmegen (1986-1992) en het St. Maartensgasthuis te Venlo (1991-1992).

Vanaf 1992 is hij full-time werkzaam op de Afdeling Klinische Psychologie van het St. Annaziekenhuis te Geldrop. Hij is lid van de PAZ (sectie Psychologen Algemene Ziekenhuizen van het NIP). In opdracht van het besiuur van de PAZ was hil achtereenvolgens lid van de commissie hartrevalidatie, secretaris van de voorbereidingswerkgroep consensus hartrevalidatie (ism het CBO) en voorzitter van de commissie verrichtingen.

Hij behaalde in 1987 de registratie lot klinisch psycholoog (NIP), in 1989 volgde het lidmaatschap en in 1993 het supervisorschap van de Vereniging voor Gedragstherapie. In 1994 werd inschrijwing verkregen in het register van psychotherapeuten (ministerie van VWSI.

Hij is ten behoeve van postacademisch onderwijs actief voor het Instituut voor Rationele Therapie te Nijmegen (cognitieve- en gedragstherapie), de post-doctorale opleiding tot klinisch psychaloog (KUN) en de Centrale RINO-groep (in het kader van de psychotherapie opleiding). 